\title{
Pesticides in Surface Water in the Lower Illinois River Basin, 1996-98
}

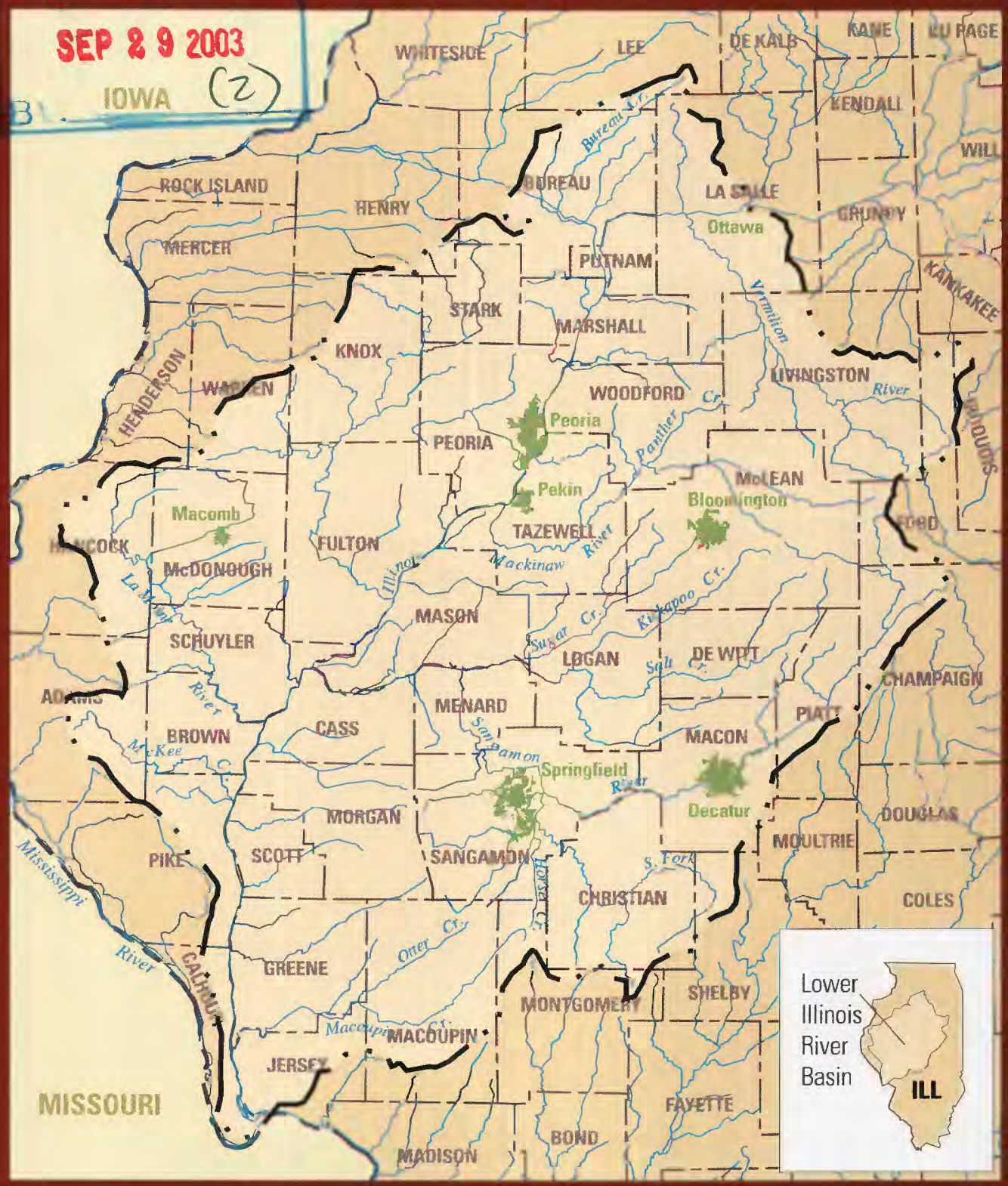

Water-Resources Investigations Report 02-4097 National Water-Quality Assessment Program 



\section{Pesticides in Surface Water in the Lower Illinois River Basin, 1996-98}

By Robin B. King

Water-Resources Investigations Report 02-4097

National Water-Quality Assessment Program 


\section{U.S. DEPARTMENT OF THE INTERIOR \\ GALE A. NORTON, Secretary}

\section{U.S. GEOLOGICAL SURVEY}

Charles G. Groat, Director

The use of firm, trade, and brand names in this report is for identification purposes only and does not constitute endorsement by the U.S.

Geological Survey.

For additional information write to:

District Chief

U.S. Geological Survey

$221 \mathrm{~N}$. Broadway Avenue

Urbana, IL 61801
Copies of this report can be purchased from:

U.S. Geological Survey

Branch of Information Services

Box 25286

Denver, CO 80225-0286 


\section{FOREWORD}

The U.S. Geological Survey (USGS) is committed to serve the Nation with accurate and timely scientific information that helps enhance and protect the overall quality of life, and facilitates effective management of water, biological, energy, and mineral resources (http://www.usgs.gov/). Information on the quality of the Nation's water resources is of critical interest to the USGS because it is so integrally linked to the long-term availability of water that is clean and safe for drinking and recreation and that is suitable for industry, irrigation, and habitat for fish and wildlife. Escalating population growth and increasing demands for the multiple water uses make water availability, now measured in terms of both quantity and quality, even more critical to the longterm sustainability of our communities and ecosystems.

The USGS implemented the National Water-Quality Assessment (NAWQA) Program to support national, regional, and local information needs and decisions related to water-quality management and policy (http://water.usgs.gov/nawqa/). Shaped by and coordinated with ongoing efforts of other Federal, State, and local agencies, the NAWQA Program is designed to answer: What is the condition of our Nation's streams and ground water? How are the conditions changing over time? How do natural features and human activities affect the quality of streams and ground water, and where are those effects most pronounced? By combining information on water chemistry, physical characteristics, stream habitat, and aquatic life, the NAWQA Program aims to provide science-based insights for current and emerging water issues and priorities. NAWQA results can contribute to informed decisions that result in practical and effective water-resource management and strategies that protect and restore water quality.

Since 1991, the NAWQA Program has implemented interdisciplinary assessments in more than 50 of the Nation's most important river basins and aquifers, referred to as Study Units (http://water.usgs.gov/ nawqa/nawqamap.html). Collectively, these Study Units account for more than 60 percent of the overall water use and population served by public water supply, and are representative of the Nation's major hydrologic landscapes, priority ecological resources, and agricultural, urban, and natural sources of contamination.
Each assessment is guided by a nationally consistent study design and methods of sampling and analysis. The assessments thereby build local knowledge about waterquality issues and trends in a particular stream or aquifer while providing an understanding of how and why water quality varies regionally and nationally. The consistent, multi-scale approach helps to determine if certain types of water-quality issues are isolated or pervasive, and allows direct comparisons of how human activities and natural processes affect water quality and ecological health in the Nation's diverse geographic and environmental settings. Comprehensive assessments on pesticides, nutrients, volatile organic compounds, trace metals, and aquatic ecology are developed at the national scale through comparative analysis of the Study-Unit findings (http://water.usgs.gov/nawqa/natsyn.html).

The USGS places high value on the communication and dissemination of credible, timely, and relevant science so that the most recent and available knowledge about water resources can be applied in management and policy decisions. We hope this NAWQA publication will provide you the needed insights and information to meet your needs, and foster increased awareness and involvement in the protection and restoration of our Nation's waters.

The NAWQA Program recognizes that a national assessment by a single program cannot address all waterresource issues of interest. External coordination at all levels is critical for a fully integrated understanding of watersheds and for cost-effective management, regulation, and conservation of our Nation's water resources. The Program, therefore, depends extensively on the advice, cooperation, and information from other Federal, State, interstate, Tribal, and local agencies, nongovernment organizations, industry, academia, and other stakeholder groups. The assistance and suggestions of all are greatly appreciated.

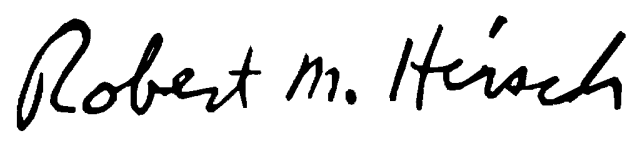

Robert M. Hirsch Associate Director forWater 



\section{CONTENTS}

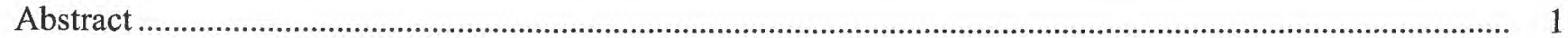

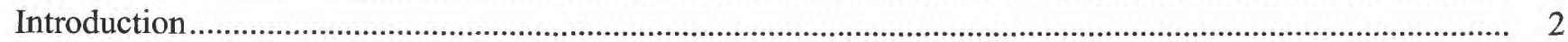

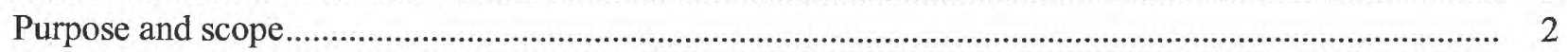

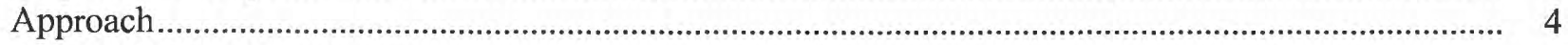

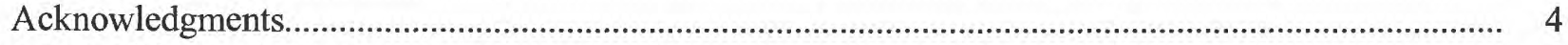

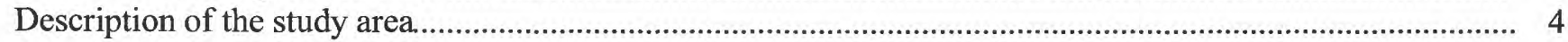

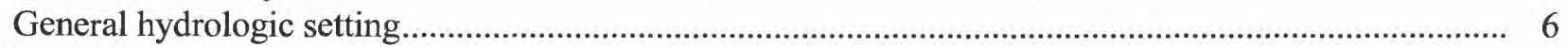

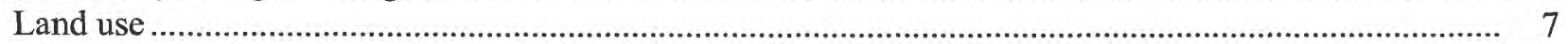

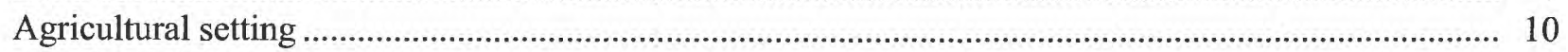

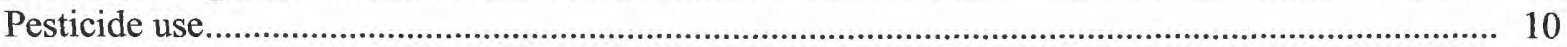

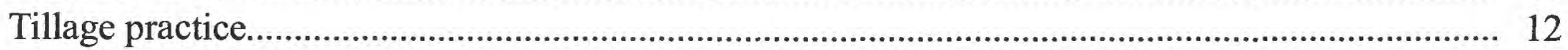

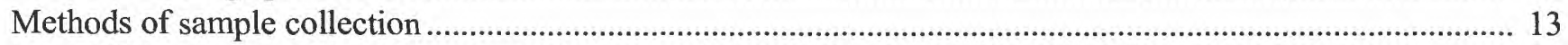

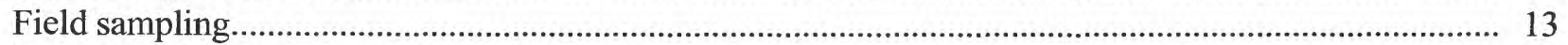

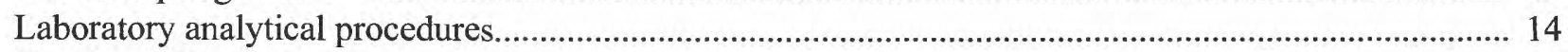

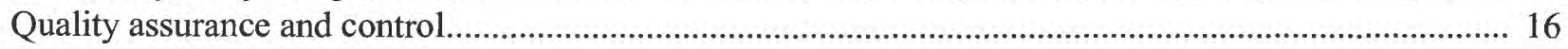

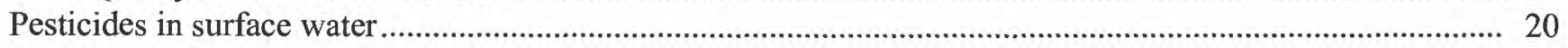

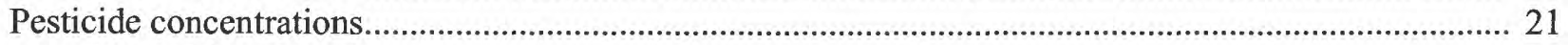

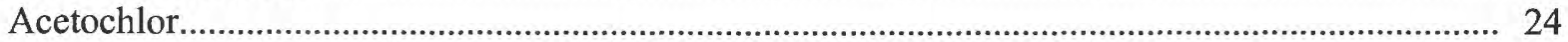

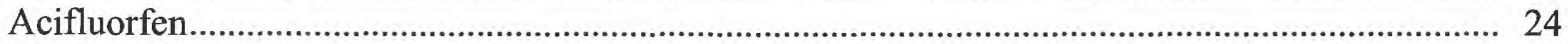

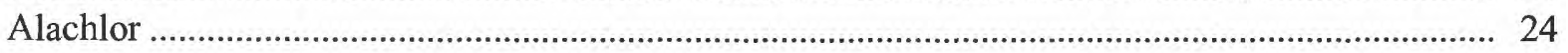

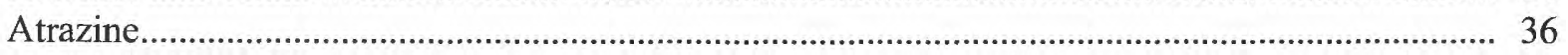

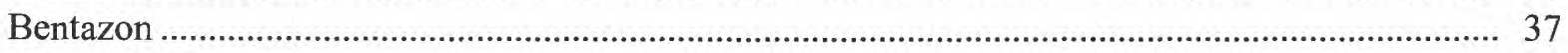

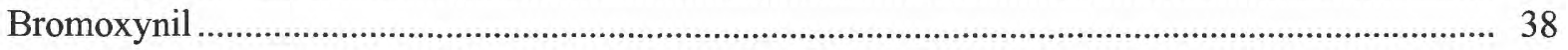

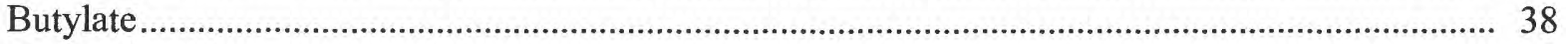

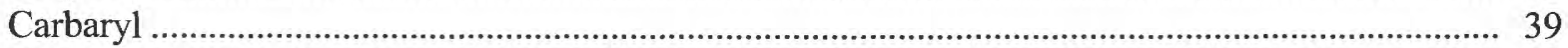

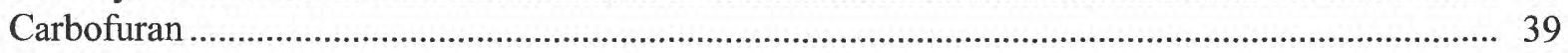

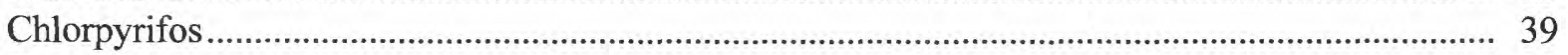

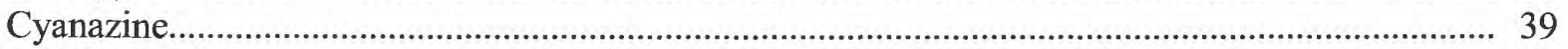

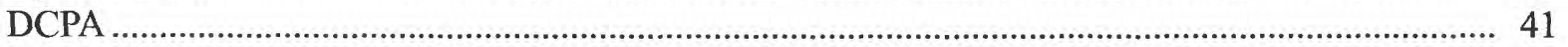

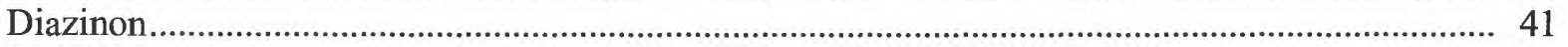

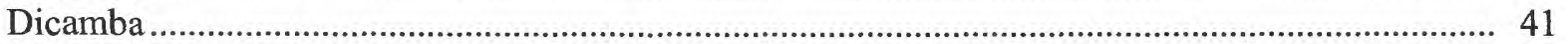

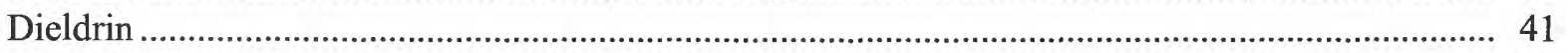

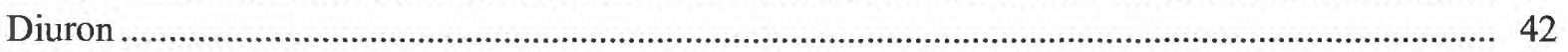

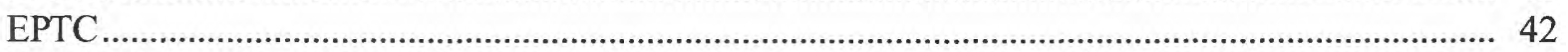

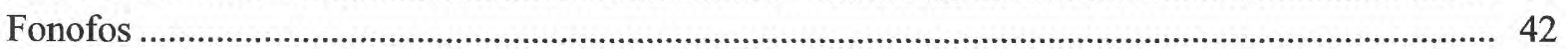

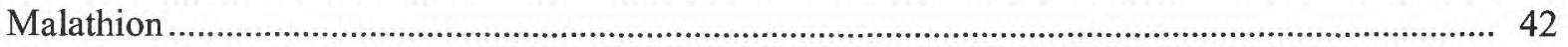

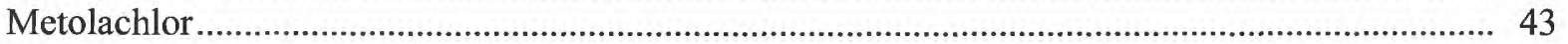

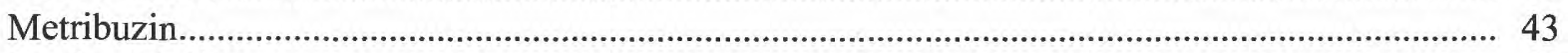

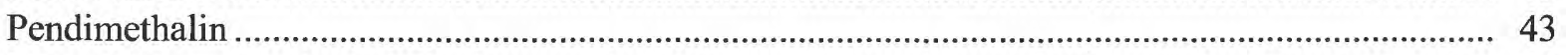

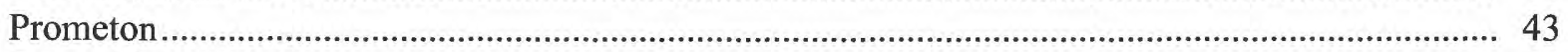

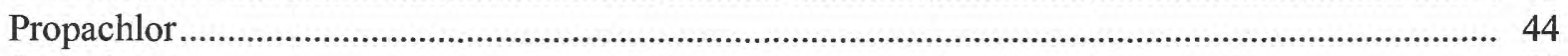

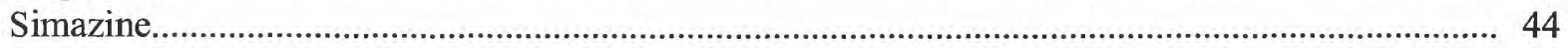

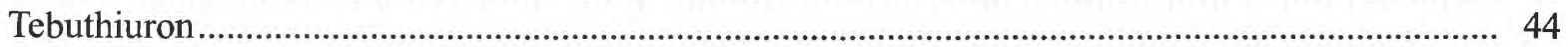

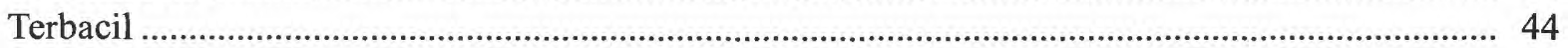


Terbufos

Triallate

Trifluralin

2,4-D

Herbicide transformation product concentrations

Chloroacetanilide-class transformation products.

Triazine-class transformation products

Estimated loads of selected herbicides.

Summary and conclusions

\section{FIGURES}

1.-3. Maps showing:

1. Location of the lower Illinois River Basin in central and western Illinois.

2. Location of pesticide sample sites in the lower Illinois River Basin.

3. Land use in the lower Illinois River Basin.

4.-8. Graphs showing:

4. Sample boxplot of pesticide concentration data

5. Concentrations of detected pesticides at all sample sites in the lower Illinois River Basin, 1996-98

6. Comparison of atrazine concentrations at intensive sample sites, by season, lower Illinois River Basin, 1997-98

7. Concentrations of selected pesticides in the Sangamon River at Monticello, lower Illinois

River Basin, during an early spring storm, post application, 1997.

8. Cyanazine concentration at the intensive sample sites in the lower Illinois River Basin, May-June 1997-98

9. Pathways for degradation of acetochlor, alachlor, and metolachlor.

10. Concentrations of selected chloroacetanilide-class herbicide transformation products and their parent products at the intensive sample sites in the lower Illinois River Basin, July-September 1998

11. Pathways for degradation of atrazine, cyanazine, and simazine

12.-14. Graphs showing:

12. Concentrations of selected triazine-class herbicide transformation products and their parent products at the intensive sample sites in the lower Illinois River Basin, July-September 1998.

13. Deethylatrazine to atrazine ratio for the Sangamon River at Monticello in the lower Illinois River Basin, October 1996-September 1998

14. Estimated loads of selected pesticides in the Illinois River Basin, Ottawa and Valley City, in the lower Illinois River Basin, 1996-98

15. Comparison of net pesticide loads in surface water to pesticide use for acetochlor, atrazine, cyanazine, and metolachlor in the lower Illinois River Basin, 1996-98.

16.-21. Graphs showing:

16. Comparison of the concentration of selected pesticides to stream discharge at the intensive sample sites in the lower Illinois River Basin, 1996-98. 
17. Relation of total chloroacetanilide- and triazine-class herbicide transformation product concentration to stream discharge in the lower Illinois River Basin, July-September 1998.

18. Comparison of annual pesticide usage to mean annual concentration for selected pesticide chemical classes, lower Illinois River Basin, 1997-98.

19. Monthly average pesticide concentration in the lower Illinois River Basin, 1996-98..

20. Relation of total pesticide concentration per sample to streamflow magnitude at all sample sites in the lower Illinois River Basin, 1996-98.

21. Comparison of average pesticide concentration to both seasonality and streamflow magnitude at all sample sites in the lower Illinois River Basin, 1996-98.

\section{TABLES}

1. Pesticide sample sites and number of samples collected in the lower Illinois River Basin, 1996-98

2. Annual mean discharge and departure from long-term mean at sample sites in the lower Illinois River Basin, 1996-98.

3. Summary of land use at pesticide sample sites in the lower Illinois River Basin.

4. Number of corn and soybean acres planted annually within the lower Illinois River Basin at selected sample sites, 1996-98

5. Estimated basinwide pesticide use at selected sample sites in the lower Illinois River Basin, 1996-98......

6. Tillage practice in the lower Illinois River Basin, 1996-98.

7. Target pesticide schedules and their method detection limits.

8. Selected pesticide transformation products, their method detection limits, and percentage of detections in the lower Illinois River Basin, July-September 1998.

9. Relative percentage differences of replicate average sample concentration for selected pesticides in the lower Illinois River Basin, 1996-98.

10. Field-spike matrix concentrations in surface-water samples in the lower Illinois River Basin, 1996-98

11. Comparison of average surrogate recovery rates among samples collected in the lower Illinois River Basin, 1996-98.

12. Summary of pesticides, herbicide transformation products, and water-quality standards in the lower Illinois River Basin, 1996-98

13. Concentrations of chloroacetanilide- and triazine-class herbicide transformation products at intensive sample sites, lower Illinois River Basin, 1996-98.

14. Estimated annual load, net-load increase, application quantity, and delivery ratio for selected pesticides in the lower Illinois River Basin, 1996-98 


\section{CONVERSION FACTORS}

\begin{tabular}{rcl}
\hline Multiply & By & To obtain \\
\hline acre-foot (acre-ft) & 1,233 & cubic meter \\
cubic foot per second $\left(\mathrm{ft}^{3} / \mathrm{s}\right)$ & 0.02832 & cubic meter per second \\
foot (ft) & 0.3048 & meter \\
gallon & 3.79 & liter \\
inch (in.) & 2.54 & centimeter \\
pound (lb) & 0.4536 & kilogram \\
quart & 0.947 & liter \\
square mile (mi $\left.{ }^{2}\right)$ & 2.590 & square kilometer \\
ton per year (ton/yr) & 2.485 & kilograms per day \\
\hline
\end{tabular}

Temperature in degrees Fahrenheit $\left({ }^{\circ} \mathrm{F}\right)$ may be converted to degrees Celsius $\left({ }^{\circ} \mathrm{C}\right)$ as follows:

$$
{ }^{\circ} \mathrm{C}=\left({ }^{\circ} \mathrm{F}-32\right) / 1.8
$$

\section{ABBREVIATED WATER-QUALITY UNITS}

Microgram per liter $(\mu \mathrm{g} / \mathrm{L})$ is a unit expressing the concentration of a chemical constituent in solution as weight (microgram) of solute per unit volume (liter) of water.

\section{OTHER ABBREVIATIONS}

BDMC 4-bromo-3, 5-dimethylphenyl-n-methylcarbamate

DCPA Dimethyl tetrachloroterephthalate

EPTC S-ethyl dipropylthiocarbamate

$\mathrm{HCH}$, alpha- benzene hexachloride

2,4-D 2,4-dichlorophenoxyacetic acid

DNOC 4, 6-Dinotro-o-cresol 


\title{
Pesticides in Surface Water in the Lower Illinois River Basin, 1996-98
}

\author{
By Robin B. King
}

\section{Abstract}

Surface-water quality samples were collected from April 1996 to September 1998 from eight locations in the Lower Illinois River Basin, a study unit of the U.S. Geological Survey's National Water-Quality Assessment program. The study area is approximately 15,600 square miles and encompasses most of central and western Illinois. The dominant land use is agricultural and most land is used for the production of corn and soybeans. About 6.9 million acres of corn and soybeans are planted annually in the lower Illinois River Basin. Conservation tillage, defined as mulch-till and no-till, is used on about 40 percent of the cropland in the study area, similar to the statewide average. Nearly 90 percent of the samples for pesticide analyses were collected at four sites: the Illinois River at Ottawa, the Illinois River at Valley City, the La Moine River at Colmar, and the Sangamon River at Monticello. Two hundred fifty-eight samples were collected and analyzed for various herbicides, insecticides, and herbicide transformation products (also referred to as degradates). Thirty-one pesticides were detected at concentrations above their respective method detection limit: 23 herbicides and 8 insecticides. An additional set of 34 samples was collected in the summer of 1998 for the analysis of herbicide transformation products. Nine herbicide transformation products were detected, all belonging to the chloroacetanilide or the triazine chemical class.

Two herbicides, atrazine and cyanazine, exceeded the associated human health drinkingwater criteria and the aquatic health-criteria. Atrazine was detected in all samples. Sixty percent of the samples ( 48 of 80 ) collected in the months of May and June had atrazine concentrations that exceeded the clean drinkingwater standard of 3 micrograms per liter $(\mu \mathrm{g} / \mathrm{L})$. The average atrazine concentration in the May to June samples was about $7.0 \mu \mathrm{g} / \mathrm{L}$. The maximum atrazine concentrations were $110 \mu \mathrm{g} / \mathrm{L}$ in the $\mathrm{La}$ Moine River at Colmar and $32 \mu \mathrm{g} / \mathrm{L}$ in the Sangamon River at Monticello. The maximum atrazine concentration in the lower Illinois River was $20 \mu \mathrm{g} / \mathrm{L}$, measured at Valley City, although most of the relatively elevated concentrations in the Illinois River sites were in the range from 5 to $8 \mu \mathrm{g} / \mathrm{L}$. The concentrations of the herbicide cyanazine exceeded the health advisory guideline of $1 \mu \mathrm{g} / \mathrm{L}$ in about 19 percent ( 15 of 80 ) of the May to June samples. The pesticides chlorpyrifos, diazinon, metolachlor, and 2,4-D exceeded aquatic health guidelines at various times from May to August. Three dominant factors that affect the presence of pesticides in streams are identified: the pesticide usage, the time-of-year (or season), and the flow condition. The pesticides with the highest usage - atrazine, metolachlor, cyanazine, and acetochlor-generally were the pesticides detected most frequently and at the highest concentrations. Notable exceptions to this general observation are alachlor and simazine, which did not have high usage but were detected frequently. The elevated pesticide concentrations were most affected by seasonality - most of these elevated concentrations were observed across all flow conditions during May to June. Flow conditions also affect pesticide concentrations, but not as much as seasonality. The maximum pesticide loads were observed between March and July on the Illinois River. The net contribution of pesticides applied in the study area to net increases in load indicates that only about 1-2 percent of the pesticides applied exit the basin through the Illinois River at Valley City. 
The chloroacetanilide-class transformation products observed in samples collected in summer 1998 persistently contained elevated concentrations relative to the associated parent pesticide compound at all locations and for all streamflow conditions. The concentration of the transformation product metolachlor ethane sulfonic acid (ESA) usually was about 10 times higher than the parent compound in the mainstem of the lower Illinois River, and in the La Moine River at Colmar and Sangamon River at Monticello sometimes up to 30 times higher. The concentrations of the transformation products acetochlor ESA and alachlor ESA persistently were elevated 5 to 10 times above the concentrations of their parent compounds. The oxanilic acid transformation products of acetochlor and metolachlor also were at higher concentrations than their parent compounds, although these concentrations were relatively lower than for the ESA transformation products. Concentrations of the atrazine transformation product deethylatrazine DEA always were below that of its parent compound. Concentrations of the triazine-class transformation product deisopropylatrazine, which is a transformation product of both atrazine and cyanazine, were higher relative to DEA concentrations, although still below the concentrations of its two parent compounds. The cyanazine transformation product cyanazine amide was at the highest absolute concentration and the highest concentration relative to its parent compound.

\section{INTRODUCTION}

The National Water-Quality Assessment (NAWQA) program of the U.S. Geological Survey (USGS) is designed to describe the status of and trends in the quality of the Nation's water resources and to link the status and trends with an understanding of the natural and human factors that affect the quality of water. The NAWQA program comprises more than 50 hydrologic basins, or study units. In each study unit, USGS staff generally collects environmental data from three components: surface water, ground water, and biology. All theNAWQA study units combined encompass approximately 40 percent of the land area of the contiguous United States, which includes about 60 to 70 percent of national water use. Each study unit will be active for 7 years, which is followed by 3 years of minimal data collection before the study unit then is reactivated. The conceptual framework and design of the NAWQA program is described in detail in Gilliom and others (1995). The lower Illinois River Basin (LIRB) is one of the study units; an approximately $15,600 \mathrm{mi}^{2}$ watershed located in central and western Illinois (fig. 1), which was activated in 1994. The Illinois River is considered part of the upper Mississippi River system. Illinois farmers, like most farmers elsewhere in the Nation, rely on pesticides to maximize crop productivity and to improve farming efficiency. The public health implications of pesticides and their transformation products in surface water are a topic of intense scientific inquiry and public policy debate. Although the numbers of farms and, to a lesser extent, the land area in farms have been steadily declining since 1910 , crop yields per acre during this same period have increased steadily (Illinois Agricultural Statistics Service, 1999; Illinois Department of Natural Resources, 1994). The increase in crop yields can be attributed primarily to improved farming methods and plant varieties, increased use of pesticides, and increased use of synthetic fertilizers. Corn and soybeans are the major crops planted and harvested in the LIRB, although small amounts of hay, oats, sorghum, and winter wheat also are produced.

\section{Purpose and Scope}

The purpose of this report is as follows:

- To document the results of water-quality sampling and analyses for selected pesticides and pesticide transformation products in the LIRB for the period 1996-98;

- To describe selected environmental conditions in the LIRB that relate to pesticide occurrence and distribution, including land use, pesticide use, hydrology, and agricultural tillage practices;

- To describe the occurrence and distribution of selected pesticides and pesticide transformation products in the surface waters of the LIRB, and compare pesticide concentrations to waterquality standards and guidelines. 


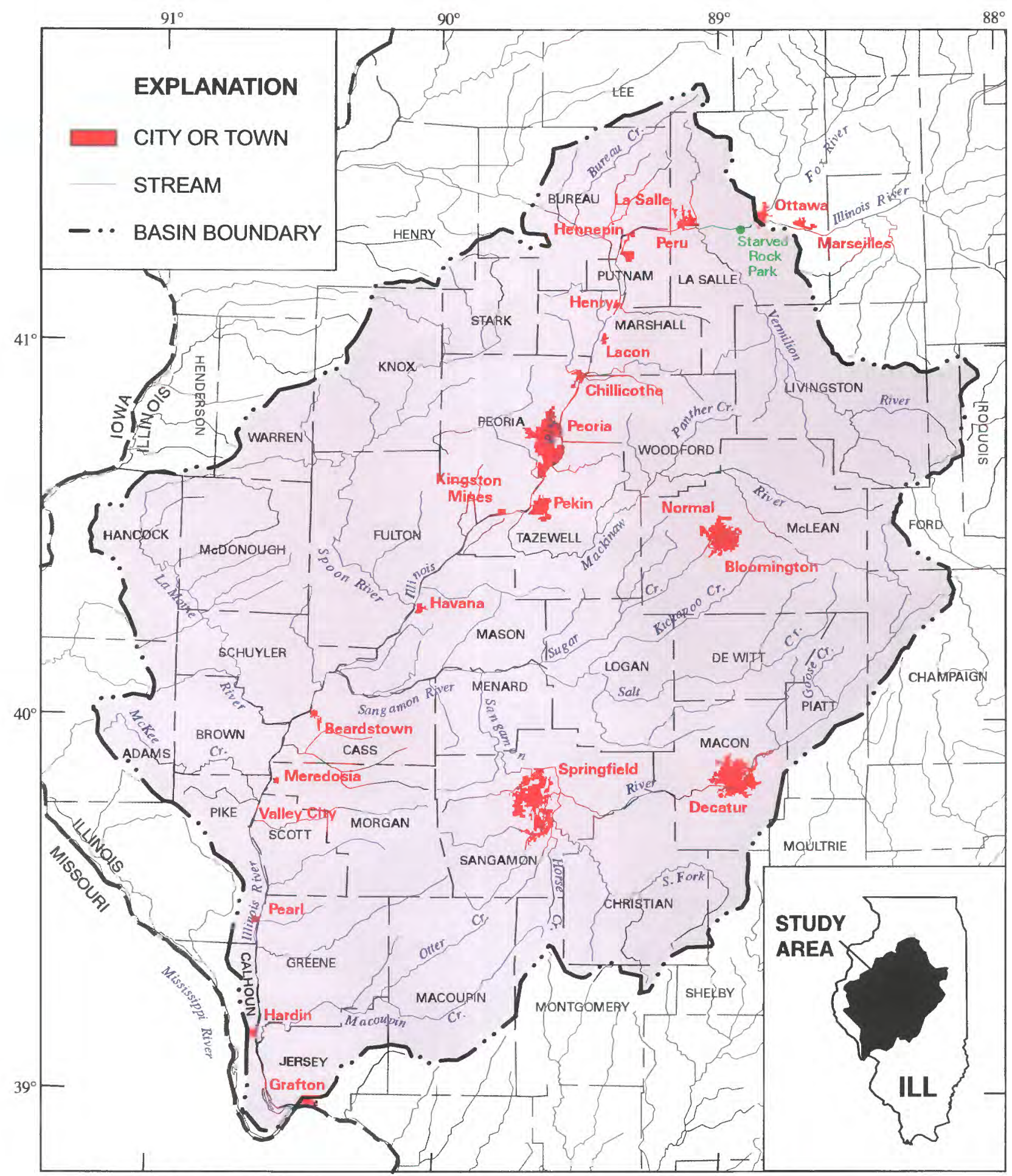

Base from U.S. Geological Survey

1:2,000,000 and 1:100,000 Digital Data

Albers Equal-Area Conic Projection

Standard Parallels $33^{\circ}$ and $45^{\circ}$, central meridian $-89^{\circ}$

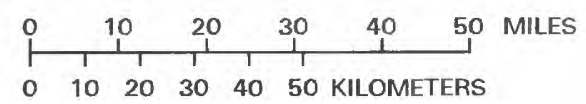

Figure 1. Location of the lower Illinois River Basin in central and western Illinois. 


\section{Approach}

The purpose of NAWQA surface-water-quality monitoring networks is to collect the appropriate information for interpreting the effects of land use on water quality. Individual monitoring sites (referred to as sample sites or fixed stations in this report) are selected primarily on the basis of land use, although other characteristics such as hydrology, physiography, and surficial geology are considered. The selection of sample sites with predominantly similar upstream land use allows general conclusions to be established on the relation of land use and water quality. These sites are designated as indicator sites. Additional sampling was done at sites with mixed upstream land use and larger drainage area; these sites are designated as integrator sites, and are intended to represent the water-quality conditions in the basin of a diverse, heterogeneous mix of land-use conditions. The frequency of sampling also is a design consideration in selecting sample sites. Sites that are sampled relatively frequently (primarily on a weekly basis) and for a relatively large number of chemical constituents, especially during the growing season, are referred to as intensive sites. Sites that are sampled relatively infrequently and for relatively fewer chemical constituents are referred to as basic sites. Surface-water samples were collected at eight sites from April 1996 through September 1998 (fig. 2). However, most of the sampling for pesticides was done at just four of these eight sites from October 1996 through September 1998. The objective of the sampling program was to monitor temporal changes in pesticide concentrations at the sample sites. The frequency of sampling was increased from March to September, during 1997-98, to document the changes in pesticide concentrations during (1) the spring planting season, a period when most agricultural pesticides are applied and (2) the growing season, a period when pesticides typically will enter the stream system in greatest quantity. Additional samples were acquired to measure pesticide concentrations during high flow conditions (generally defined as greater than 10-percent exceedance probability), particularly those that occurred in the spring, after pesticide application. Agricultural practices were summarized from data provided by the Illinois Agricultural Statistics Service (IASS), a cooperative agency of the U.S. Department of Agriculture (USDA), and from the Natural Resources Conservation Service (NRCS), an agency of the USDA. Descriptions of land use, hydrology, and climate were summarized from data provided by the
Illinois Department of Natural Resources (IDNR), Illinois State Water Survey (ISWS), and USGS.

\section{Acknowledgments}

The author thanks David Dupré of the USGS, who assisted in the collection of nearly all the surfacewater samples and performed many related duties. Sheila Sahu, formerly of the USGS, assisted with the pesticides data base and preparation of field equipment. Dennis McKenna of the Illinois Department of Agriculture reviewed the draft report and provided many helpful and insightful comments.

\section{DESCRIPTION OF THE STUDY AREA}

The study area is $15,600 \mathrm{mi}^{2}$ and includes the basin area extending from the Illinois River at Ottawa to the Illinois River at Valley City (fig. 2). This area encompasses most of central and west-central Illinois and includes approximately one-third of the land area of the State of Illinois, including all or part of 41 counties. In 1999, the population in the study area was about 1.4 million, with over half this number living in the counties of Macon, McLean, Peoria, Sangamon, and Tazewell (U.S. Department of Commerce, 2000). The most populated cities in the basin in 1999 included Peoria, Springfield, Decatur, and Bloomington. The topography generally is flat, although many gentle rolling hills are present, especially near the rivers and in the western part of the basin. The predominant land use is agricultural. In 1994, approximately 88 percent of the land area was used for agricultural purposes (computed from the Illinois Department of Natural Resources, 1996), with corn and soybean production accounting for most of the agricultural land use (Illinois Agricultural Statistics Service, 1999). Nearly all of the study area is located in the Till Plains Section of the Central Lowland physiographic province, and the land surface was modified by episodes of intense continental-scale glaciation. Warner (1998) provides a detailed description of the environmental setting for the LIRB, which originally was designed to include the area downstream of the Illinois River at Valley extending to the mouth of the Illinois River near Grafton, Missouri. Adolphson and others (2002) provides a detailed description of selected geomorphologic, sediment, and biota characteristics for the LIRB. 


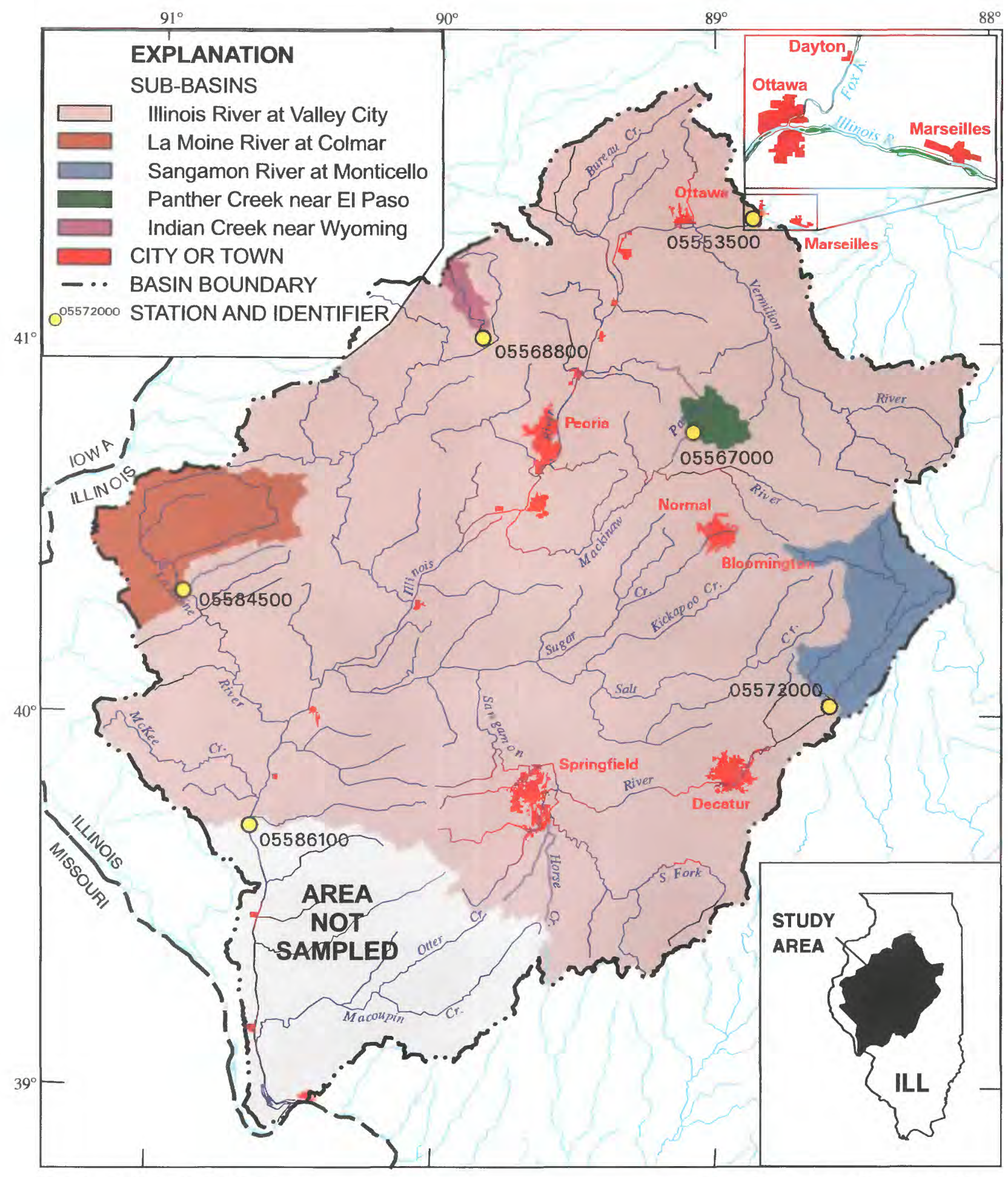

Base from U.S. Geological Survey 1:24,000 Digital Data

Albers Equal-Area Conic Projection

Standard Parallels $33^{\circ}$ and $45^{\circ}$, central meridian $-89^{\circ}$

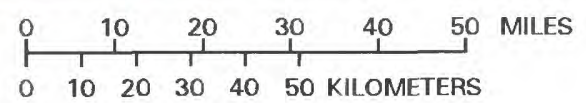

Figure 2. Location of pesticide sample sites in the lower Illinois River Basin. 


\section{General Hydrologic Setting}

Water sampling for pesticide analyses was conducted primarily at four sites (fig. 2): the Illinois River at Ottawa $\left(11,000 \mathrm{mi}^{2}\right)$, the Illinois River at Valley City $\left(26,600 \mathrm{mi}^{2}\right)$, the La Moine River at Colmar $\left(650 \mathrm{mi}^{2}\right)$, and the Sangamon River at Monticello (550 $\mathrm{mi}^{2}$ ). No samples were collected downstream of the Illinois River at Valley City, thus, inflow from Macoupin Creek $\left(960 \mathrm{mi}^{2}\right)$, which is part of the original LIRB design, was not considered in this study. The Valley City site was selected as the terminus of the study area as it is the most downstream location on the mainstem of the Illinois River at which discharge can be determined reliably. Additional samples were collected at the Fox River at Dayton $\left(2,640 \mathrm{mi}^{2}\right)$; the Illinois River at Marseilles $\left(8,260 \mathrm{mi}^{2}\right)$; Panther Creek near El Paso $\left(94 \mathrm{mi}^{2}\right)$; and Indian Creek near Wyoming $\left(63 \mathrm{mi}^{2}\right)$. The Fox River at Dayton and the Illinois River at Marseilles were sampled most often in 1996, before a redesign of the LIRB water-quality-sampling network resulted in combining these two sample sites into the Illinois River at Ottawa. The streamflow at the Illinois River at Ottawa consists of the sum of the streamflow from the Fox River at Dayton and the Illinois River at Marseilles (fig. 2). The La Moine River at Colmar and the Sangamon River at Monticello are designated as intensive-indicator sample sites because these basins are 90 and 96 percent agricultural, respectively (modified from Illinois Department of Natural Resources, 1996). The Illinois River sites at Ottawa and Valley City are designated as intensiveintegrator sample sites because these stations represent larger sub-basins in area and consider a larger variety of land-use conditions. The entry point of the study area, the Illinois River at Ottawa, receives inflow from the stream network of the Chicago metropolitan area, the Fox River, and the Kankakee River northeast of the LIRB. The Panther Creek near El Paso and the Indian Creek near Wyoming, the two smallest sites in the water-quality-sampling network, were sampled intermittently during the $1996-98$ pesticide-sampling period. The name, USGS station number, location, drainage area, and number of pesticide samples collected annually for the fixed sites are listed in table 1.

Table 1. Pesticide sample sites and number of samples collected in the lower Illinois River Basin, 1996-98

[Samples include U.S. Geological Survey (USGS) pesticide schedule 2051 and/or 2010 compounds. Latitude and longitude in units of degrees-minutes-seconds; $\mathrm{mi}^{2}$, square miles; -, no sample collected]

\begin{tabular}{|c|c|c|c|c|c|c|c|c|}
\hline \multirow{2}{*}{$\begin{array}{l}\text { USGS station } \\
\text { name }\end{array}$} & \multirow{2}{*}{$\begin{array}{l}\text { USGS station } \\
\text { number }\end{array}$} & \multirow{2}{*}{ Latitude } & \multirow{2}{*}{ Longitude } & \multirow{2}{*}{$\begin{array}{l}\text { Drainage } \\
\text { area }\left(\mathrm{mi}^{2}\right)\end{array}$} & \multicolumn{4}{|c|}{ Number of pesticide samples } \\
\hline & & & & & 1996 & 1997 & 1998 & Total \\
\hline $\begin{array}{l}\text { llinois River at } \\
\text { Maresilles }\end{array}$ & 05543500 & $41^{\circ} 19^{\prime} 37^{\prime \prime}$ & $88^{\circ} 43^{\prime} 03^{\prime \prime}$ & 8,259 & 9 & 1 & - & 10 \\
\hline $\begin{array}{l}\text { Fox River at } \\
\text { Dayton }\end{array}$ & 05552500 & $41^{\circ} 23^{\prime} 02^{\prime \prime}$ & $88^{\circ} 47^{\prime} 23^{\prime \prime}$ & 2,642 & 9 & 1 & - & 10 \\
\hline $\begin{array}{l}\text { Illinois River at } \\
\text { Ottawa }\end{array}$ & 05553500 & $41^{\circ} 20^{\prime} 32^{\prime \prime}$ & $88^{\circ} 50^{\prime} 48^{\prime \prime}$ & 10,949 & - & 16 & 16 & 32 \\
\hline $\begin{array}{l}\text { Panther Creek near } \\
\text { El Paso }\end{array}$ & 05567000 & $40^{\circ} 46^{\prime} 05^{\prime \prime}$ & $89^{\circ} 04^{\prime} 30^{\prime \prime}$ & 93.9 & 3 & 2 & 3 & 8 \\
\hline $\begin{array}{l}\text { Indian Creek near } \\
\text { Wyoming }\end{array}$ & 05568800 & $41^{\circ} 01^{\prime} 06^{\prime \prime}$ & $89^{\circ} 50^{\prime} 07^{\prime \prime}$ & 62.7 & 3 & 3 & 3 & 9 \\
\hline $\begin{array}{l}\text { Sangamon River at } \\
\text { Monticello }\end{array}$ & 05572000 & $40^{\circ} 01^{\prime} 51^{\prime \prime}$ & $88^{\circ} 35^{\prime} 20^{\prime \prime}$ & 550 & 4 & 44 & 31 & 79 \\
\hline $\begin{array}{l}\text { LaMoine River at } \\
\text { Colmar }\end{array}$ & 05584500 & $40^{\circ} 01^{\prime} 51^{\prime \prime}$ & $88^{\circ} 35^{\prime} 20^{\prime \prime}$ & 655 & - & 38 & 31 & 69 \\
\hline $\begin{array}{l}\text { Illinois River at } \\
\text { Valley City }\end{array}$ & 05586100 & $39^{\circ} 42^{\prime} 12^{\prime \prime}$ & $90^{\circ} 38^{\prime} 43^{\prime \prime}$ & 26,743 & 8 & 19 & 18 & 45 \\
\hline
\end{tabular}


The climate in Illinois is classified as continental. Typically, the summers are warm and humid, with occasional heavy rain and thunderstorm activity. Winters tend to be cold and dry. Relatively largemagnitude and short-duration changes in precipitation, temperature, humidity, and wind direction are frequent (Huff and Angel, 1989). Annual mean precipitation ranges from about 36 inches in the northern part of the study area to about 38 inches in the southern part. Annual mean temperature ranges from about $50^{\circ} \mathrm{F}$ in the north to about $54^{\circ} \mathrm{F}$ in the south. Annual mean growing-degree days, which are used to estimate the growth and development of plants and insects during the growing season, ranges from about 3,500 in the north to about 4,000 in the south (Illinois State Water Survey, 2000). Although year-to-year precipitation varies considerably, the annual mean rainfall and annual mean soil and air temperature provide excellent climatic conditions for agricultural production.

Precipitation and stream discharge varied considerably in the 1996-98 data-collection period. In 1996, precipitation was below the annual average, although it was much above average in the months of May to July, especially in the northern part of the study area. In 1997, precipitation was from below average to much below average over the entire study area. In 1998, precipitation generally was above average, particularly in June. The annual mean stream discharges at the sample sites are compared to the longterm mean annual discharge in table 2. The discharges at the Illinois River sites of Marseilles andValley City were within 5 to 10 percent of their long-term mean in 1996 and 1997, but both substantially were higher in 1998. All sample sites had higher mean stream discharge in 1998 than in either 1996 or 1997, with higher mean discharge in 1998 than their respective long-term mean annual discharges.

\section{Land Use}

The primary land use in the LIRB is in agriculture for the production of corn and soybeans (fig. 3). The study area includes the land area upstream of the Illinois River at Valley City and downstream of the Illinois River at Ottawa, and is $15,600 \mathrm{mi}^{2}$. Land use in this area is approximately 88.0-percent agricultural, 6.7-percent forest, 2.7-percent urban or developed, 1.1-percent barren, 1.0-percent water, and 0.5 -percent wetland (modified from Illinois Department of Natural Resources, 1996). Detailed land-use information for the pesticide sampling sites downstream of the Illinois River at Ottawa is summarized for the USGS level-II categories (Anderson and others, 1978) in table 3. Twenty USGS level-II land-use categories are present in the study area.

Table 2. Annual mean discharge and departure from long-term mean at sample sites in the lower Illinois River Basin, 1996-98 $\left[\mathrm{ft}^{3} / \mathrm{s}\right.$, cubic feet per second; percent, percent departure from long-term (period of record) mean annual discharge; --, no data]

\begin{tabular}{lccccccc}
\hline \multicolumn{1}{c}{ Sample station } & \multicolumn{2}{c}{ Annual mean discharge $\left(\mathrm{ft}^{\mathbf{3}} / \mathbf{s}\right)$} & \multicolumn{2}{c}{$\begin{array}{c}\text { Long-term mean } \\
\text { annual discharge } \\
\text { (period of record) }\end{array}$} & \multicolumn{2}{c}{ Departure from mean (percent) } \\
& $\mathbf{1 9 9 6}$ & $\mathbf{1 9 9 7}$ & $\mathbf{1 9 9 8}$ & $\mathbf{1 9 9 6}$ & $\mathbf{1 9 9 8}$ \\
\hline $\begin{array}{l}\text { Illinois River at } \\
\text { Valley City }\end{array}$ & 22,060 & 21,030 & 31,130 & $\begin{array}{c}22,910 \\
(1939-98)\end{array}$ & -3.7 & -8.2 & 35.9 \\
$\begin{array}{l}\text { Illinois River at at } \\
\text { Marseilles }\end{array}$ & 10,480 & 11,090 & 12,500 & $\begin{array}{c}10,840 \\
(1920-98)\end{array}$ & -3.3 & 2.3 & 15.3 \\
$\begin{array}{l}\text { Fox River at } \\
\text { Dayton }\end{array}$ & 2,530 & 1,852 & 2,072 & $\begin{array}{c}1,796 \\
(1915-98)\end{array}$ & 40.9 & 3.1 & 15.4 \\
$\begin{array}{l}\text { Lamoine River at } \\
\text { Colmar }\end{array}$ & 568 & 437 & 708 & $\begin{array}{c}462 \\
(1945-98)\end{array}$ & 22.9 & -5.4 & 53.2 \\
$\begin{array}{l}\text { Sangamon River at } \\
\text { Monticello }\end{array}$ & 304 & 382 & 677 & $\begin{array}{c}422 \\
(1908-98)\end{array}$ & -28.0 & -9.5 & 60.4 \\
$\begin{array}{l}\text { Indian Creek near } \\
\text { Wyoming }\end{array}$ & 35.1 & 53.7 & 82.3 & $\begin{array}{c}50.4 \\
(1960-98)\end{array}$ \\
$\begin{array}{l}\text { Panther Creek near } \\
\text { El Paso }\end{array}$ & -- & 40.0 & 86.4 & $\begin{array}{c}57.0 \\
(1950-98)\end{array}$ & -30.3 & 6.5 & 63.3 \\
\hline
\end{tabular}




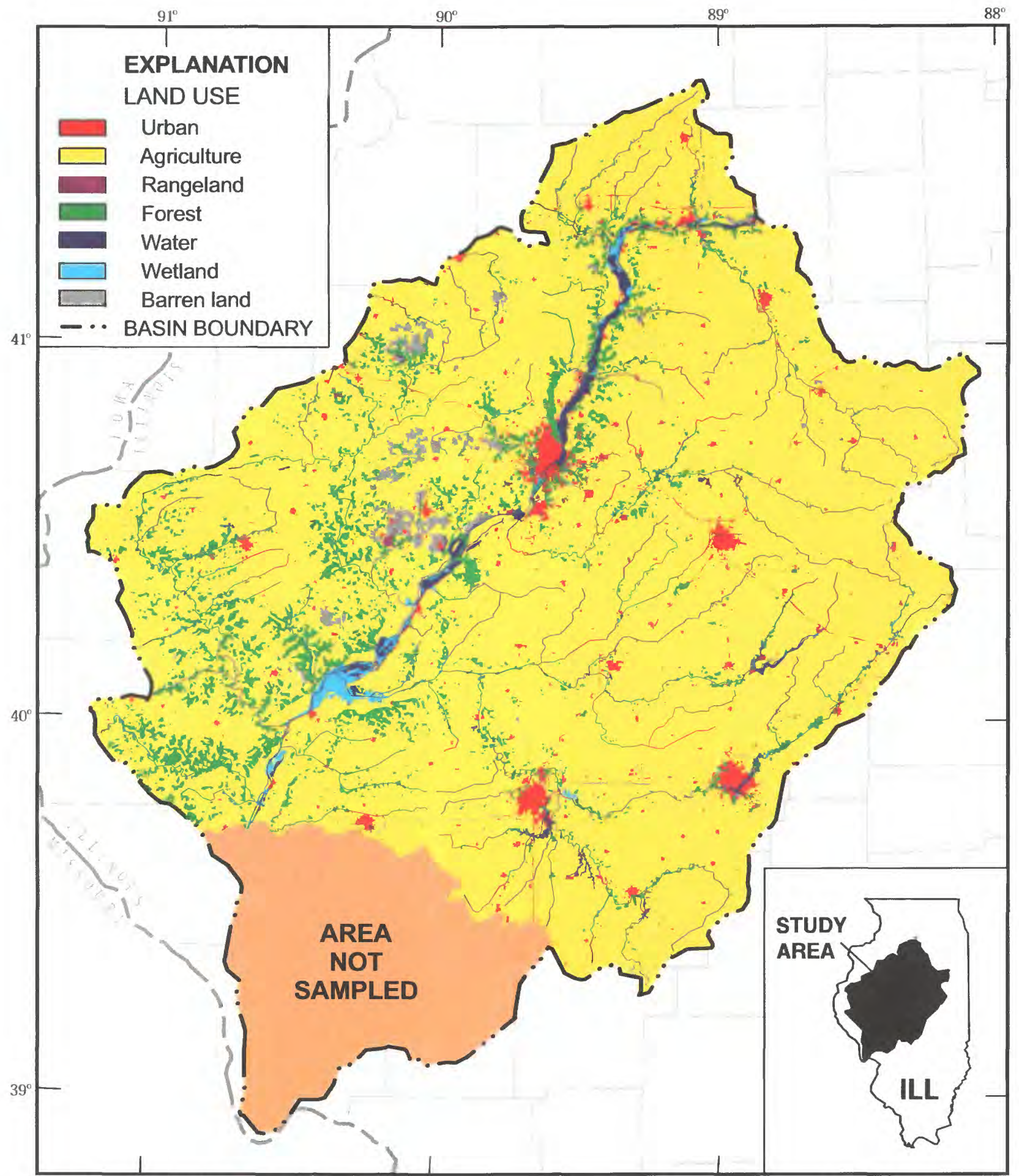

Base from U.S. Geological Survey 1:2,000,000 Digital Data

Albers Equal-Area Conic Projection

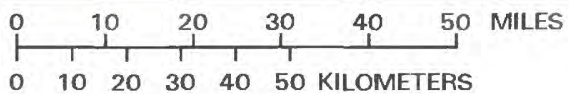

Standard Parallels $33^{\circ}$ and $45^{\circ}$, central meridian $-89^{\circ}$

Figure 3. Land use in the lower Illinois River Basin (modified from the Illinois Department of Natural Resources, 1996). 
Table 3. Summary of land use at pesticide sample sites in the lower Illinois River Basin

[U.S. Geological Survey (USGS) level II land-use category, in percent of upstream area; <, less than; ---, land-use category not present. Land-use percentages per sampling site may not add to 100 percent because of rounding]

\title{
(A) Land-use category descriptions:
}

\author{
11 residential \\ 12 commercial and services \\ 13 industrial \\ 14 transportation, communications, and utilities \\ 16 mixed urban or built-up land \\ 17 other urban or built-up land \\ 21 cropland and pasture \\ 22 orchards, groves, and nurseries \\ 23 confined feeding operations \\ 24 other agricultural land \\ 32 shrub and brush rangeland
}

41 deciduous forest land

42 evergreen forest land

43 mixed forest land

51 streams and canals

52 lakes

53 reservoirs

61 forested wetlands

62 nonforested wetlands

75 strip mines, quarries, and gravel pits

76 transitional areas

\begin{tabular}{|c|c|c|c|c|c|}
\hline \multirow{2}{*}{$\begin{array}{l}\text { Land use } \\
\text { (A) }\end{array}$} & \multicolumn{5}{|c|}{ USGS station number } \\
\hline & 05567000 & 05568800 & 05572000 & 05584500 & 05586100 \\
\hline 11 & 0.4 & 1.0 & 1.1 & 0.6 & 1.5 \\
\hline 12 & .2 & .5 & .3 & .4 & .5 \\
\hline 13 & $<.1$ & .1 & --- & $<.1$ & .1 \\
\hline 14 & .2 & .2 & .3 & $<.1$ & .3 \\
\hline 16 & .1 & --- & .1 & .1 & .1 \\
\hline 17 & .1 & .5 & .2 & .1 & .2 \\
\hline 21 & 98.7 & 96.4 & 96.2 & 89.9 & 88.0 \\
\hline 22 & -- & --- & $<.1$ & --- & $<.1$ \\
\hline 23 & .1 & .1 & $<.1$ & $<.1$ & $<.1$ \\
\hline 24 & $<.1$ & --- & $<.1$ & $<.1$ & $<.1$ \\
\hline 32 & -- & -- & --- & -- & $<.1$ \\
\hline 41 & .2 & 1.1 & 1.5 & 8.6 & 6.6 \\
\hline 42 & --- & -- & --- & --- & $<.1$ \\
\hline 43 & -- & --- & - & -- & $<.1$ \\
\hline 51 & --- & --- & --- & --- & .1 \\
\hline 52 & --- & --- & --. & --- & .1 \\
\hline 53 & $<.1$ & --- & .1 & .1 & .8 \\
\hline 61 & --- & --- & --- & --- & .4 \\
\hline 62 & --- & --- & --- & --- & .1 \\
\hline 75 & --- & --- & .1 & .1 & .3 \\
\hline 76 & --- & .1 & --- & $<.1$ & .9 \\
\hline
\end{tabular}




\section{Agricultural Setting}

During the 1996-98 sampling period, an annual average of 3.6 million acres were planted for corn and an annual average of 3.3 million acres were planted for soybeans (Illinois Agricultural Statistics Service, 1997, 1998, 1999). (This planted acreage is measured by the basin area downstream of the Illinois River at Ottawa and upstream of the Illinois River at Valley City). This annual average of about 6.9 million planted acres for corn and soybean production represents approximately 70 percent of the study area, and nearly 80 percent of the land area classified as agricultural. The number of acres planted for corn and soybeans remained fairly steady during 1996-98, except for a notable increase in soybean planting in 1998. In 1998, the Illinois corn and soybean harvest ranked second in the United States (Illinois Agricultural Statistics Service, 1999, p. 12). The number of corn and soybean acres planted annually in the basin area above the sample sites Illinois River at Valley City (from downstream of Ottawa), La Moine River at Colmar, and Sangamon River at Monticello for the 1996-98 sampling period is shown in table 4 .

Pesticides are applied for the purpose of increasing crop yield by controlling weeds, grasses, and certain insects. Several pesticide types are applied in the study area. Pesticide use patterns can change as new products enter the market, the type and occurrence of pests shift, and as cropping patterns change.

Herbicides, which control nuisance weeds and grasses, account for nearly all the pesticides applied in the study area. Nearly all corn and soybean acreage in the study area receives at least one application of herbicide per growing season, which represents part of a long-term increase in the State and national percentage of crop acreage treated with herbicides. However, this increased percentage of treated crop acreage has been accompanied by a general decrease in the pounds of active herbicide ingredient applied per acre (Illinois Department of Natural Resources, 1994, p. 73-77). In general, each acre of cropland has become more productive. Corn yield and the Crop Production Index (CPI), which is computed by the Illinois Department of Agriculture, have steadily increased since 1950 (Illinois Department of Natural Resources, 1994, p. 70; Illinois Agricultural Statistics Service, 1999, p. 20).

Because of the major increase in corn and soybean production, mechanical disturbances to the soil have increased greatly over the last 50 years. Since 1945 , a variety of Federal farm programs have provided incentives to divert farmland from crop production to other uses. Diverted cropland can be important for reducing soil erosion. Soil erosion also has been reduced through conservation tillage practices, which are defined as when at least 30 percent of the soil surface is protected by crop residue after spring planting. Since the early 1980 s, Illinois farmers have steadily been increasing the percentage of their cropproducing acreage under conservation tillage.

\section{Pesticide Use}

Nearly all agricultural pesticides used in the study area are applied for the purpose of corn and soybean production. Pesticide use (by weight) was computed for each of the years 1996, 1997, and 1998 from data provided by the Illinois Agricultural Statistics Service (IASS) (1997, 1998, and 1999). The use within the basin was computed for selected pesticides for the Illinois River at Valley City, the La Moine River at Colmar, and the Sangamon River at Monticello. The IASS publishes pesticide application rates for corn and soybeans as a statewide average, based on an annual survey of several hundred farmers within the State. The IASS application data include the percentage of area applied, the average number of applications, the average rate per application (in pounds

Table 4. Number of corn and soybean acres planted annually within the lower Illinois River Basin at selected sample sites, 1996-98

[Modified from Illinois Agricultural Statistics Service, 1997-99; all values in acres]

\begin{tabular}{lrrrrrr}
\hline \multirow{2}{*}{ Sample station } & \multicolumn{2}{c}{1996} & \multicolumn{2}{c}{1997} & \multicolumn{2}{c}{1998} \\
& Corn & Soybeans & \multicolumn{1}{c}{ Corn } & Soybeans & \multicolumn{1}{c}{ Corn } & Soybeans \\
\hline Illinois River at Valley City & $3,580,000$ & $3,070,000$ & $3,620,000$ & $3,070,000$ & $3,540,000$ & $3,660,000$ \\
Lamoine River at Colmar & 135,000 & 125,000 & 140,000 & 133,000 & 138,000 & 140,000 \\
Sangamon River at Monticello & 153,000 & 145,000 & 155,000 & 147,000 & 150,000 & 152,000 \\
\hline
\end{tabular}


per acre), and the average application rate per crop year (in pounds per acre). IASS provide these data for 40 pesticides ( 34 herbicides and 6 insecticides) used on both corn and soybeans. However, only 16 of these pesticides (14 herbicides and 2 insecticides) were detected in samples collected during this study, and those pesticides are the only ones considered in the computation of the basinwide pesticide use. A threestep procedure was used to compute use from the IASS pesticide application data:

1) The total corn and soybean acreage for calendar years 1996, 1997, and 1998 were collated from county-level IASS data (Illinois Agricultural Statistics Service, 1996, 1997, and 1998). These data report the number of acres planted per county and by crop. A geographic information system (GIS) then was used to compute the respective county area within each of the basins considered.

2) A net-effective application rate was computed for each pesticide for which usage data were available by multiplying, for each pesticide, the average application rate per crop year by the average percentage of the area applied. The neteffective application rate incorporates that any given pesticide generally is not applied to the entire planted acreage of corn or soybean crops, and that pesticides sometimes are applied more than once during the growing season.

3) The net-effective application rates for the selected pesticides were multiplied by the acreage of corn and soybeans planted within the basin, yielding the basinwide use. The basinwide use is reported in pounds of active ingredient (AI) applied per year for each of the 16 pesticides for which application data were available.

The computed pesticide application volumes are based on two assumptions. First, it is assumed that the planted corn and soybean acreage is distributed uniformly across each county. Second, it is assumed that the IASS-reported pesticide application rate per crop year remains uniform across the study area. Thus, the computed application mass, considered as pounds of AI, is related closely to the number of corn and soybean acres planted. There can be substantial limitations of these assumptions, as the application rate of a given pesticide might vary significantly across the study area. For example, the herbicide acetochlor is not used in some counties in the LIRB because of manufacturer restrictions. Further, some pesticides, such as 2-4D and trifluralin, tend to be used in relatively greater quantity in the southern portion than the northern portion of the study area (Dennis McKenna, Illinois Department of Agriculture, written commun., 2000). However, the IASS reports the pesticide application rates on only a statewide average basis. These reported statewide averages are based upon a statistical analysis of hundreds of confidential surveys submitted by individual farmers. Thus, the IASSreported statewide averages are the most detailed information available regarding pesticide application rates and use in the LIRB. The estimated pesticide usage for the entire study area (the land area upstream of the Illinois River at Valley City and downstream of the Illinois River at Ottawa) is summarized in table 5 for the period 1996-98. Also included are the annual pesticide use for the La Moine River at Colmar and the Sangamon River at Monticello.

The most commonly applied pesticides in the study area upstream of the Illinois River at Valley City, defined as estimated use in excess of 500 tons (1 million pounds) per year for the data-collection period, are the herbicides acetochlor, atrazine, cyanazine, and metolachlor. The estimated use of acetochlor, atrazine, and metolachlor were relatively consistent during the 1996-98 growing periods, remaining within approximately 10 percent of the 3-year average. However, the estimated use of cyanazine varied over the same period, as the 1997 and 1998 rates are less than 60 percent of the 1996 rate. The herbicides 2,4-D, bentazon, dicamba, and trifluralin, and the insecticides chlopyrifos and terbufos, each were applied in an estimated range of nearly 100 tons to just over 330 tons per year. The relative use of 2,4-D, trifluralin, and terbufos varied greatly during the 1996-98 growing periods. The estimated use of the herbicide pendimethalin decreased from about 750 tons in 1996 to less than 350 tons in 1998, while estimated alachlor use decreased from more than 45 tons in 1996 to none in 1998. The decline in pendimethalin and alachlor use is for economic reasons, as farmers are substituting the use of these compounds with other more effective herbicides (Thomas A. Walker, Illinois Department of Agriculture, oral commun., 2000). The pattern of pesticide use for the areas upstream of the La Moine River at Colmar and the Sangamon River at Monticello closely resemble the patterns observed for the entire study area (table 5). 
Table 5. Estimated basinwide pesticide use at selected sample sites in the lower Illinois River Basin, 1996-98

[Modified from Illinois Agricultural Statistics Service, 1997, 1998, 1999; lb-ai, pounds of active ingredient]

\begin{tabular}{|c|c|c|c|c|c|c|c|c|c|}
\hline \multirow[t]{2}{*}{ Pesticide } & \multicolumn{3}{|c|}{$\begin{array}{l}\text { IIlinois River at Valley City } \\
\text { Application rate (lb-ai) }\end{array}$} & \multicolumn{3}{|c|}{$\begin{array}{l}\text { La Moine River at Colmar } \\
\text { Application rate (lb-ai) }\end{array}$} & \multicolumn{3}{|c|}{$\begin{array}{c}\text { Sangamon River at Monticello } \\
\text { Application rate (Ib-ai) }\end{array}$} \\
\hline & 1996 & 1997 & 1998 & 1996 & 1997 & 1998 & 1996 & 1997 & 1998 \\
\hline Acetochlor & $1,940,000$ & $2,170,000$ & $1,740,000$ & 73,400 & 83,800 & 67,800 & 741 & 1,910 & 1,210 \\
\hline Acifluorfen & 15,700 & 39,900 & 29,200 & 639 & 1,720 & 1,120 & 4,000 & 3,550 & NONE \\
\hline Alachlor & 93,700 & 82,900 & NONE & 3,540 & 3,200 & NONE & 137,000 & 143,000 & 150,000 \\
\hline Atrazine & $3,210,000$ & $3,350,000$ & $3,540,000$ & 21,000 & 129,000 & 137,000 & 61,600 & 19,600 & 12,900 \\
\hline Bentazon & 266,000 & 422,000 & 310,000 & 10,400 & 17,700 & 11,900 & 3,100 & 2,510 & 3,360 \\
\hline Bromoxynil & 72,600 & 58,600 & 79,300 & 2,740 & 2,260 & 3,090 & 13,000 & 28,800 & 13,200 \\
\hline Chlorpyrifos & 303,000 & 672,000 & 312,000 & 12,100 & 25,900 & 11,500 & 96,600 & 52,300 & 57,100 \\
\hline Cyanazine & $2,260,000$ & $1,220,000$ & $1,350,000$ & 85,400 & 47,100 & 52,400 & 12,800 & 10,900 & 10,400 \\
\hline Dicamba & 299,000 & 254,000 & 246,000 & 11,300 & 9,820 & 9,570 & 99,100 & 118,000 & 110,000 \\
\hline Metolachlor & $2,330,000$ & $2,710,000$ & $2,600,000$ & 88,400 & 106,000 & 101,000 & 2,240 & 3,630 & 1,590 \\
\hline Metribuzin & 47,300 & 75,700 & 38,400 & 1,930 & 3,270 & 1,470 & 71,600 & 54,700 & 28,200 \\
\hline Pendimethalin & $1,510,000$ & $1,140,000$ & 678,000 & 61,700 & 49,300 & 26,000 & 3,940 & 4,310 & 2,820 \\
\hline Simazine & 92,000 & 101,000 & 66,600 & 3,490 & 3,880 & 2,590 & 8,250 & 15,400 & 6,460 \\
\hline Terbufos & 193,000 & 360,000 & 152,000 & 5,920 & 13,900 & 7,440 & 10,200 & 22,300 & 9,960 \\
\hline Trifluralin & 216,000 & 466,000 & 240,000 & 8,820 & 20,100 & 9,190 & 83,000 & 93,100 & 74,000 \\
\hline 2,4-D & 487,000 & 186,000 & 579,000 & 19,400 & 7,700 & 26,100 & 83,000 & 93,100 & 74,000 \\
\hline
\end{tabular}

\section{Tillage Practice}

Farmers can use land-management practices to reduce erosion, increase soil moisture, and to reduce the transport of agricultural chemicals from their fields (Seta and others, 1993). These methods generally are referred to as conservation land-management (CLM) practices. The Illinois Department of Agriculture (IDA), in cooperation with the NRCS, annually conducts a transect survey of tillage practices in the State. The IDA transect survey provides detailed information on tillage systems used in planting corn and soybean crops, and has been performed annually since 1994. The IDA transect survey classifies tillage practices into four categories: conventional, low-till, mulch-till, and no-till. Conventional tillage is defined as when less than 15 percent of the soil surface is left undisturbed. Low-till is defined as when 15 to 30 percent of the soil surface is left undisturbed. Mulchtill is defined as when at least 30 percent of the residue from the previous crop remains on the soil surface after planting a crop. No-till is defined as when the soil surface remains virtually undisturbed from harvest through planting. Mulch-till and no-till are together known as conservation tillage.

The crop residue left on the soil surface with conservation tillage practices is important because it shields the ground from the eroding effects of rain and helps retain soil moisture for crops. However, the effects of tillage practices on the fate and transport of pesticides is less clear. Some studies suggest that conservation tillage practices do not reduce the transport of pesticides to surface water (Baker and Shiers, 1989; Blevins and others, 1990; among others). In contrast, other studies suggest that conservation tillage reduces pesticide loading to surface water and runoff (Hall and others, 1984; Seta and others, 1993; Hall and Mumma, 1994; among others). Other studies claim that conservation tillage techniques, particularly when used over a long time period, substantially increase the movement of pesticides into ground water (because of the improved subsurface drainage and higher infiltration rates), thus, increasing ground-water contamination. This discussion is summarized in Borin (1997, p. 3-16). 
The tillage practices used in the study area were summarized using the IDA transect-survey data for the 1996-98 data-collection period. The IDA reports tillage practices for both corn and soybeans for each county in the State. The data were computed by summing, for each crop and tillage practice, the land area of each county (or fractional component) within the study area, from upstream of the Illinois River at Valley City. The summary of tillage practices is shown in table 6. The distribution of tillage practices in the study area for 1996-98 closely resembles the tillage practices the IDA reported for the entire State. For example, conservation tillage was used in the study area on $39.1,44.0$, and 39.0 percent of the active agricultural land area in 1996, 1997, and 1998, respectively. By comparison, IDA reports the statewide conservation-tillage rate as $39.0,43.7$, and 38.3 percent of active agricultural land area for 1996, 1997, and 1998, respectively (Allen Gulso, Illinois Department of Agriculture, written commun., 2000).

Table 6. Tillage practice in the lower Illinois River Basin, 1996-98

[Modified from the Illinois Department of Agriculture. Conventional, less than 15-percent undisturbed soil; Low-till, 15-30 percent undisturbed soil; Mulch-till, 30 percent or more crop residue present; No-till, soil surface is virtually undisturbed, $\%$, percent land area in tillage category]

\begin{tabular}{ccccc}
\hline \multirow{2}{*}{ Year } & \multirow{2}{*}{ Conventional } & \multirow{2}{*}{ Low-till } & \multicolumn{2}{c}{ Conservation tillage } \\
& & & Mulch-till & No-till \\
\hline 1996 & $36.7 \%$ & $24.2 \%$ & $16.4 \%$ & $22.7 \%$ \\
1997 & $34.0 \%$ & $22.0 \%$ & $19.1 \%$ & $24.9 \%$ \\
1998 & $35.7 \%$ & $25.3 \%$ & $15.4 \%$ & $23.6 \%$ \\
\hline
\end{tabular}

During the $1996-98$ period of water-quality sampling, the percentage of the study area in conservation tillage fluctuated. The land area in conservation tillage peaked in 1997, and was smaller in 1996 and 1998. This fluctuation is because above average precipitation occurred during the early stage of the growing season over much of the study area in 1996 and 1998; thus, farmers had to either plant later than normal or replant crops entirely. There has been a general trend in Illinois toward decreased use of conventional tillage and increased use of either low-till or conservation-tillage methods. This trend has been encouraged by the State of Illinois conservation program called $\mathrm{T}$ by 2000 , a mandate to reduce soil erosion to tolerable levels (Illinois Department of Agriculture, 2000). Between 1994 and 1999, the amount of crops planted in conventionally tilled soil has decreased by 2 million acres statewide, and most of these acres are now in conservation tillage.

\section{METHODS OF SAMPLE COLLECTION}

Measuring the pesticide concentrations and their transformation products in stream water is a complex and detailed process requiring a number of interrelated steps. The primary goal of field sampling is to collect a water sample that is representative of the ambient pesticide concentration in the stream water and to transport the sample to a laboratory for determination of the presence and concentrations of the target pesticides. Additional samples are collected for quality control. Quality-control samples can measure the potential variability in observed concentrations, provide insight to pesticide degradation and matrix interference during processing and shipping, and can document contamination from external sources that might bias measured pesticide concentrations. A detailed description of NAWQA methods and protocols is available on the World Wide Web (U.S. Geological Survey, 2000a).

\section{Field Sampling}

Water-quality samples were collected, processed, and shipped to the USGS National Water-Quality Laboratory (NWQL) according to methods described by Shelton (1994). Samples were collected along a cross-sectional transect of the stream using the equalwidth-increment sampling method described by Edwards and Glysson (1988). Nearly all the samples taken from the Illinois River were collected by boat, although a few Illinois River samples were collected from bridges because of frozen stream conditions or mechanical problems with the sampling boat. Samples collected from the other streams, which include the Sangamon River, La Moine River, Fox River, Panther Creek, and Indian Creek, all were acquired either from the bridge or by wading, depending upon stream and 
weather conditions. Some samples were collected when the stream was frozen, which required cutting holes through the ice to reach the flowing stream water.

Whole-water samples were passed through a Teflon cone splitter, a device used to composite the sample and then separate it into appropriate portions for further processing or shipping and analysis by the NWQL (Capel and others, 1995). Nearly all the pesticide samples collected in 1997 and 1998 were field processed using a solid phase extraction (SPE) technique (Shelton, 1994) and the SPE cartridges then were shipped to NWQL. Samples collected in 1996 were shipped whole and then extracted by SPE at the NWQL. All pesticide sample water or cartridges were chilled immediately, processed, and transported in chilled containers by overnight shipping to the NWQL near Denver, Colorado. Samples collected for measurement of pesticide transformation products similarly were handled and shipped to the USGS Organic Geochemistry Research Laboratory (OGRL) in Lawrence, Kansas, except that transformation product samples were shipped whole for extraction by OGRL.

The stream-water field conditions were measured at the time of sample collection, including temperature, $\mathrm{pH}$, alkalinity, and specific conductance. Samples were collected concurrently for measurement of nutrients, major inorganic ions, suspended sediment, and dissolved and suspended organic carbon, and also shipped to NWQL after appropriate preservation. A continuous-measurement USGS streamflow-gaging station was located at each sample site except for the Illinois River at Ottawa. Stream discharge for the Illinois River at Ottawa was assumed to be the sum of the discharges from the stations at the Illinois River at Marseilles and the Fox River at Dayton.

\section{Laboratory Analytical Procedures}

Surface-water samples were analyzed for pesticides and selected pesticide transformation products. The water-quality laboratories used in this study, NWQL and OGRL, report pesticide concentrations relative to the method detection limit (MDL). The MDL is established for specific pesticides and can vary substantially for different pesticides. The MDL is defined as "the minimum concentration of a substance that can be identified, measured, and reported with 99-percent confidence that the analyte concentration is greater than zero, determined from the analysis of a sample in a given matrix containing the analyte" (U.S. Geological Survey, 2000a). The MDL considers many different possibilities of analytical uncertainty, and assumes that at a measured concentration equal to the MDL, the chance of a false positive is 1 percent. Pesticide concentrations sometimes are estimated. Pesticide concentrations are reported as estimated for any of three reasons: (1) the reported concentration is below the MDL but the sample matched the appropriate spectral value of the target pesticide; (2) the calculated concentration exceeds the upper limit of the calibration range; (3) the analytical method performs poorly for the target pesticide. (The pesticides carbaryl, carbofuran, terbacil, and the pesticide transformation product deethylatrazine typically have been difficult to measure in the laboratory, and most of the reported concentrations for these pesticides are reported as estimated). All of the pesticide and pesticide transformation product concentrations in this report use MDLs established by either NWQL or OGRL.

Samples analyzed by NWQL included 88 target pesticides of which nearly all are herbicides and the remainder are either insecticides or pesticide transformation products. The NWQL target pesticides and transformation products are listed in table 7 , and include NWQL schedules 2010 and 2051 and associated USGS parameter codes (Zaugg and others, 1995). The presence and concentration of pesticides were measured at NWQL by gas chromatography/mass spectrometry (GC/MS) (Zaugg and others, 1995). In addition, analyses included the measurement of nine herbicide transformation products from the chloroacetanilide class and the triazine class. These chemical constituents were analyzed at the OGRL and are listed in table 8 . The OGRL transformation product determination methods are described in Zimmerman and Thurman (1999). 
Table 7. Target pesticide schedules and their method detection limits (MDL)

[USGS, U.S. Geological Survey; Zaugg and others, 1995; Werner and others, 1996; $\mu \mathrm{g} / \mathrm{L}$, microgram per liter]

\begin{tabular}{|c|c|c|c|c|c|}
\hline \multicolumn{3}{|c|}{ Schedule 2010 pesticides } & \multicolumn{3}{|c|}{ Schedule 2051 pesticides } \\
\hline $\begin{array}{c}\text { USGS } \\
\text { parameter } \\
\text { code }\end{array}$ & Compound name & $\begin{array}{c}\text { MDL } \\
(\mu \mathrm{g} / \mathrm{L})\end{array}$ & $\begin{array}{c}\text { USGS } \\
\text { parameter } \\
\text { code }\end{array}$ & Compound name & $\begin{array}{c}\text { MDL } \\
(\mu g / L)\end{array}$ \\
\hline 49260 & Acetochlor & 0.002 & 39742 & $2,4.5-\mathrm{T}$ & 0.035 \\
\hline 46342 & Alachlor & .002 & 39732 & $2,4-\mathrm{D}$ & .035 \\
\hline 04040 & Atrazine, desethyl & .002 & 38746 & 2,4-DB & .035 \\
\hline 39632 & Atrazine & .001 & 49315 & Acifluorfen & .035 \\
\hline 82686 & Azinphos, methyl & .001 & 49312 & Aldicarb & .016 \\
\hline 82673 & Benfluralin & .002 & 49313 & Aldicarb sulfone & .016 \\
\hline 04028 & Butylate & .002 & 49314 & Aldicarb sulfoxide & .021 \\
\hline 82680 & Carbaryl & .028 & 38711 & Bentazon & .014 \\
\hline 82674 & Carbofuran & .028 & 04029 & Bromacil & .035 \\
\hline 38933 & Chlorpyrifos & .004 & 49311 & Bromoxynil & .035 \\
\hline 04041 & Cyanazine & .004 & 49310 & Carbaryl & .028 \\
\hline 82682 & DCPA & .002 & 49309 & Carbofuran & .028 \\
\hline 34653 & DDE, p,p'- & .006 & 49308 & 3-hydroxy Carbofuran & .014 \\
\hline 39572 & Diazinon & .002 & 49307 & Chloramben & .011 \\
\hline 39381 & Dieldrin & .001 & 49306 & Chlorothalonil & .035 \\
\hline 82660 & Diethylanilide & .003 & 49305 & Clopyralid & .050 \\
\hline 82677 & Disulfoton & .017 & 49304 & Dacthal & .017 \\
\hline 82668 & EPTC & .002 & 38442 & Dicamba & .035 \\
\hline 82663 & Ethalfluralin & .004 & 49303 & Dichlobenil & .020 \\
\hline 82672 & Ethoprop & .003 & 49302 & Dichlorprop & .032 \\
\hline 04095 & Fonofos & .003 & 49301 & Dinoseb & .035 \\
\hline 34253 & $\mathrm{HCH}, \alpha-$ & .002 & 49300 & Diuron & .050 \\
\hline 39341 & $\mathrm{HCH}, \gamma$-(Lindane) & .004 & 49299 & DNOC & .035 \\
\hline 82666 & Linuron & .002 & 49298 & Esfenvalerate & .019 \\
\hline 39532 & Malathion & .005 & 49297 & Fenuron & .013 \\
\hline 39415 & Metolachlor & .002 & 38811 & Fluometuron & .035 \\
\hline 82630 & Metribuzin & .004 & 38478 & Linuron & .018 \\
\hline 82671 & Molinate & .004 & 38482 & MCPA & .050 \\
\hline 82684 & Napropamide & .003 & 38487 & МСРB & .035 \\
\hline 39542 & Parathion, ethyl & .004 & 38501 & Methiocarb & .026 \\
\hline 82667 & Parathion, methyl & .006 & 49296 & Methomyl & .017 \\
\hline 82669 & Pebulate & .004 & 49295 & 1-Naphthol & .007 \\
\hline 82683 & Pendimethalin & .004 & 49294 & Neburon & .015 \\
\hline 82687 & Permethrin & .005 & 49293 & Norflurazon & .024 \\
\hline 82664 & Phorate & .002 & 49292 & Oryzalin & .019 \\
\hline 04037 & Prometon & .018 & 38866 & Oxamyl & .018 \\
\hline 82676 & Pronamide & .003 & 49291 & Picloram & .050 \\
\hline 04024 & Propachlor & .007 & 49236 & Propham & .035 \\
\hline 82679 & Propanil & .004 & 38538 & Propoxur & .035 \\
\hline 82685 & Propargite & .013 & 38762 & Silvex & .021 \\
\hline 04035 & Simazine & .005 & 49235 & Triclopyr & .050 \\
\hline 82681 & Thiobencarb & .002 & & & \\
\hline 82670 & Tebuthiuron & .010 & & & \\
\hline 82665 & Terbacil & .007 & & & \\
\hline 82675 & Terbufos & .013 & & & \\
\hline 82678 & Triallate & .001 & & & \\
\hline 82661 & Trifluralin & .002 & & & \\
\hline
\end{tabular}


Table 8. Selected pesticide transformation products, their method detection limits, and percentage of detections in the lower Illinois River Basin, July-September 1998

[USGS, U.S. Geological Survey; MDL, method detection limit; $\mu \mathrm{g} / \mathrm{L}$, microgram per liter; $\%$, percentage of samples with detections above the MDL]

\begin{tabular}{clcc}
\hline $\begin{array}{c}\text { USGS } \\
\text { parameter code }\end{array}$ & \multicolumn{1}{c}{ Metabolite name } & $\begin{array}{c}\text { MDL } \\
(\mu \mathrm{g} / \mathrm{L})\end{array}$ & $\begin{array}{c}\text { Number of } \\
\text { detections (\%) }\end{array}$ \\
\hline 50010 & Cyanazine amide (CAM) & 0.05 & 56 \\
04040 & Deethylatrazine (DEA) & .04 & 100 \\
04038 & Deisopropylatrazine (DIA) & .04 & 82 \\
61029 & Acetachlor (ESA) & .20 & 97 \\
61030 & Acetochlor oxanilic acid (OXA) & .20 & 62 \\
50009 & Alachlor (ESA) & .20 & 94 \\
61031 & Alachlor oxanilic acid (OXA) & .20 & 3 \\
61043 & Metolachlor (ESA) & .20 & 100 \\
61044 & Metolachlor oxanilic acid (OXA) & .20 & 76 \\
\hline
\end{tabular}

\section{Quality Assurance and Control}

Quality-control (QC) samples processed in this study were of four types (Shelton, 1994): replicate samples, field blanks, field-matrix spikes, and fieldsurrogate spikes. A replicate sample is collected at the same time as the environmental sample and processed identically. This sample provides an estimate of the precision of the pesticide concentration values and can be used to evaluate the consistency of target pesticide identification. Field blanks are designed to demonstrate that contamination has not been introduced during sample collection, field processing, shipping, or laboratory processing. Field blanks are processed using water that is certified free of any detectable pesticides. Generally, if sampling protocols have been followed correctly, field-blank results should not report any detection of pesticide contamination. Field-matrix spikes involve adding a precise amount of a known pesticide mixture to environmental replicate samples. The field-matrix spike laboratory analysis then should yield specific concentrations of the target pesticides present in the mixture, which can be computed by subtracting the estimated pesticide concentration from the analytically determined pesticide concentration. The last type of QC sample, the field-surrogate spike, is used to measure the recovery rate of compounds structurally similar to the target pesticide compounds, but which do not occur in natural waters. Field-surrogate spikes were created by adding a $1-\mathrm{mL}$ mixture containing known concentrations of several compounds (surrogates) to the environmental water-quality sample during the SPE process. The surrogate recovery rate is measured by comparing the analytically determined concentration to the theoretical concentration.

The relative percentage differences between the pesticide concentrations determined in environmental samples and the replicate sample determinations for selected herbicides above the MDL are shown in table 9. The greatest differences were with the triazineclass herbicides: atrazine, metribuzin, and simazine, that ranged from 10 to 12 percent. Alachlor and diazinon replicate sample results were identical to the associated environmental sample results, whereas acetochlor, cyanazine, metolachlor and the transformation product deethylatrazine indicated differences in results ranging from about 2 to about 6 percent. On average, the absolute difference between environmental samples and replicate samples is about 6 percent. In every instance where the environmental sample concentrations for the schedules 2010 and 2051 compounds were at or below the MDL, the associated replicate sample concentrations also were at or below the MDL. 
Table 9. Relative percentage differences of replicate average sample concentration for selected pesticides in the lower Illinois River Basin, 1996-98

[MDL, method detection limit; $N$, number of samples above the method detection limit (MDL); In all cases, if the environmental sample concentration is below the MDL, the replicate sample also is below the MDL. $\mu \mathrm{g} / \mathrm{L}$, micrograms per liter; $\%$, relative difference in percent]

\begin{tabular}{lcccc}
\hline Pesticide compound & $\mathbf{N}$ & $\begin{array}{c}\text { Environmental } \\
\text { sample mean } \\
\text { concentration } \\
(\mu \mathrm{g} / \mathrm{L})\end{array}$ & $\begin{array}{c}\text { Replicate } \\
\text { sample mean } \\
\text { concentration } \\
(\mu \mathrm{g} / \mathrm{L})\end{array}$ & $\begin{array}{c}\text { Difference } \\
(\%)\end{array}$ \\
\hline Acetochlor & 4 & 0.164 & 0.167 & -1.8 \\
Alachlor & 4 & .026 & .026 & Same \\
Atrazine & 6 & .026 & .023 & +11.5 \\
Deethylatrazine & 6 & .078 & .073 & +6.4 \\
Cyanazine & 6 & .271 & .279 & -3.0 \\
Diazinon & 3 & .019 & .019 & Same \\
Metolachlor & 6 & .333 & .335 & -6.0 \\
Metribuzin & 3 & .016 & .014 & +12.5 \\
Prometon & 6 & .020 & .022 & -10.0 \\
Simazine & 4 & .026 & .023 & +11.5 \\
& & & \\
Average relative percentage difference of & & +6.3 \\
environmental sample to replicate sample &
\end{tabular}

Seven field blanks were processed during sampling. Nearly all of the field blanks were free of any contamination of the 88 compounds that compose the 2010 and 2051 pesticide schedules. The primary exception is atrazine, which tested false positive in four of seven cases, in concentrations ranging from 0.002 to $0.005 \mu \mathrm{g} / \mathrm{L}$, slightly above the atrazine MDL of $0.001 \mu \mathrm{g} / \mathrm{L}$. Metolachlor and DCPA also tested positive in one case each, at a detected concentration of $0.003 \mu \mathrm{g} / \mathrm{L}(\mathrm{MDL}=0.002 \mu \mathrm{g} / \mathrm{L})$ and $0.003 \mu \mathrm{g} / \mathrm{L}$ (MDL $=0.002 \mu \mathrm{g} / \mathrm{L})$, respectively. Thus, the field blanks were free of any contamination in over 99 percent of the possible cases.

Eight field-matrix spikes were processed for each of the pesticides on schedule 2010, and from three to six field-matrix spikes were processed for each of the pesticides on schedule 2051. The method estimates a recovery rate for each pesticide, and compares this estimated value to the actual measured concentration, where actual measured concentration is computed by subtracting the environmental concentration from the total field-matrix spike concentration. In general, the recovery rates for the schedule 2010 pesticides were good, with 40 of 47 pesticides exceeding 80 -percent recovery, and 26 of 47 within 90-percent recovery (table 10). The recovery rate for schedule 2051 pesticides was not as good; 24 out of 40 pesticides exceeded 80 -percent recovery, and only 7 of 40 pesticides were within 90-percent recovery (table 10).

Field-surrogate spikes were processed by adding three surrogates, alpha $\mathrm{HCH}-\mathrm{d} 6$, diazinon-d10, and terbuthylazine, to all schedule 2010 samples, and the surrogate BDMC to the schedule 2051 environmental samples. Mean surrogate recovery rates for schedule 2010 pesticides were good, ranging from 95.0 percent to 106.2 percent (table 11). The mean surrogate recovery rate for BDMC was worse, at 86.4 percent (table 11). This recovery rate can provide insight to how the target pesticides might have behaved during sample processing and shipping, as the surrogates are similar structurally to the target pesticides. 
Table 10. Field-spike matrix concentrations in surface-water samples in the lower Illinois River Basin, 1996-98

[The matrix mixtures were designed to yield the computed concentration. $\mathrm{N}$, number of samples analyzed for the compound; $\mu \mathrm{g} / \mathrm{L}$, micrograms per liter]

\begin{tabular}{|c|c|c|c|}
\hline Compound & $\mathbf{N}$ & $\begin{array}{c}\text { Measured mean } \\
\text { concentration }(\mu \mathrm{g} / \mathrm{L})\end{array}$ & $\begin{array}{c}\text { Computed } \\
\text { concentration }(\mu \mathrm{g} / \mathrm{L})\end{array}$ \\
\hline \multicolumn{4}{|l|}{ Schedule 2010} \\
\hline ACETOCHLOR & 8 & 0.109 & 0.10 \\
\hline ALACHLOR & 8 & .109 & .10 \\
\hline ATRAZINE & 8 & .084 & .10 \\
\hline BENFLURALIN & 8 & .086 & .10 \\
\hline BUTYLATE & 8 & .101 & .10 \\
\hline CARBARYL & 8 & .795 & .10 \\
\hline CARBOFURAN & 8 & .149 & .10 \\
\hline CHLORPYRIFOS & 8 & .092 & .10 \\
\hline CYANAZINE & 8 & .117 & .10 \\
\hline DCPA & 8 & .097 & .10 \\
\hline DDE P P- & 8 & .069 & .10 \\
\hline DETHYLATRAZINE & 8 & .069 & .10 \\
\hline DIAZINON & 8 & .094 & .10 \\
\hline DIELDRIN D & 8 & .108 & .10 \\
\hline DIETHYLANALINE & 8 & .079 & .10 \\
\hline DISULFOTON & 8 & .073 & .10 \\
\hline EPTC & 8 & .088 & .10 \\
\hline ETHALFLURALIN & 8 & .086 & .10 \\
\hline ETHOPROP & 8 & .091 & .10 \\
\hline FONOFOS & 8 & .097 & .10 \\
\hline HCH ALPHA-D & 8 & .098 & .10 \\
\hline HCH GAMMA-D & 8 & .106 & .10 \\
\hline LINURON & 8 & .124 & .10 \\
\hline MALATHION & 8 & .111 & .10 \\
\hline METHYLAZINPHOS & 8 & .190 & .10 \\
\hline METHYLPARATHION & 8 & .097 & .10 \\
\hline METOLACHLOR & 8 & .088 & .10 \\
\hline METRIBUZIN & 8 & .092 & .10 \\
\hline MOLINATE & 8 & .090 & .10 \\
\hline NAPROPAMIDE & 8 & .110 & .10 \\
\hline PARATHION & 8 & .086 & .10 \\
\hline PEBULATE & 8 & .095 & .10 \\
\hline PENDIMETHALIN & 8 & .090 & .10 \\
\hline PERMETHRIN & 8 & .026 & .03 \\
\hline PHORATE & 8 & .090 & .10 \\
\hline PROMETON & 8 & .089 & .10 \\
\hline PRONAMIDE & 8 & .093 & .10 \\
\hline PROPACHLOR & 8 & .115 & .10 \\
\hline PROPANIL & 8 & .096 & .10 \\
\hline PROPARGITE & 8 & .134 & .10 \\
\hline SIMAZINE & 8 & .098 & .10 \\
\hline TEBUTHIURON & 8 & .097 & .10 \\
\hline
\end{tabular}


Table 10. Field-spike matrix concentrations in surface-water samples in the lower Illinois River Basin, 1996-98-Continued

\begin{tabular}{|c|c|c|c|}
\hline Compound & $\mathbf{N}$ & $\begin{array}{c}\text { Measured mean } \\
\text { concentration }(\mu \mathrm{g} / \mathrm{L})\end{array}$ & $\begin{array}{c}\text { Computed } \\
\text { concentration }(\mu \mathrm{g} / \mathrm{L})\end{array}$ \\
\hline TERBACIL & 8 & 0.093 & 0.10 \\
\hline TERBUFOS & 8 & .093 & .10 \\
\hline THIOBENCARB & 8 & .096 & .10 \\
\hline TRIALLATE & 8 & .087 & .10 \\
\hline TRIFLURALIN & 8 & .085 & .10 \\
\hline \multicolumn{4}{|l|}{ Schedule 2051} \\
\hline $2,45-\mathrm{T}$ & 5 & 0.824 & 1.00 \\
\hline $2,4 \mathrm{D}$ & 6 & .680 & 1.00 \\
\hline $2,4 \mathrm{DB}$ & 6 & .912 & 1.00 \\
\hline ACIFLUORFEN & 6 & .720 & 1.00 \\
\hline ALDICARB & 5 & .317 & .99 \\
\hline ALDICARB SULFONE & 6 & 1.292 & 1.00 \\
\hline ALDICARB SULFXDE6 & 6 & .918 & .99 \\
\hline BENTAZON & 6 & .848 & .99 \\
\hline BROMACIL & 6 & .813 & 1.00 \\
\hline BROMOXYNIL & 6 & .873 & .99 \\
\hline CARBARYL & 6 & .795 & 1.00 \\
\hline CARBOFURAN & 6 & .948 & 1.00 \\
\hline CARBOFURAN-3HDXY & 6 & 1.303 & 1.00 \\
\hline CHLORAMBEN & 3 & .843 & 1.00 \\
\hline CHLOROTHALONIL & 6 & .380 & .72 \\
\hline CLOPYRALID & 6 & .237 & 1.00 \\
\hline DACTHL-MA & 6 & .902 & 1.02 \\
\hline DICAMBA & 6 & .630 & .99 \\
\hline DICHLOBENIL & 6 & .615 & 1.00 \\
\hline DICHLORPROP & 6 & .783 & .99 \\
\hline DINOSEB & 6 & .870 & .99 \\
\hline DIURON & 6 & .882 & .99 \\
\hline DNOC & 6 & .748 & .99 \\
\hline FENURON & 6 & .875 & .99 \\
\hline FLUOMETURON & 6 & .845 & 1.00 \\
\hline LINURON & 6 & .870 & 1.00 \\
\hline MCPA & 6 & .615 & 1.00 \\
\hline MCPB & 6 & .815 & 1.00 \\
\hline METHIOCARB & 6 & .813 & 1.00 \\
\hline METHOMYL & 3 & .910 & 1.00 \\
\hline NEBURON & 6 & .975 & 1.00 \\
\hline NORFLURAZON & 6 & .923 & 1.00 \\
\hline ORYZALIN & 6 & .772 & 1.00 \\
\hline OXAMYL & 6 & .687 & 1.00 \\
\hline PICLORAM & 6 & .427 & 1.00 \\
\hline PROPHAM & 3 & 1.133 & 1.00 \\
\hline PROPOXUR & 6 & .877 & .99 \\
\hline SILVEX & 6 & .885 & .99 \\
\hline TRICLOPYR & 6 & .805 & 1.00 \\
\hline
\end{tabular}


Table 11. Comparison of average surrogate recovery rates among samples collected in the lower Illinois River Basin, 1996-98

[USGS, U.S. Geological Survey; N, number of samples anaylzed for surrogate concentration. Values are in percent surrogate recovered]

\begin{tabular}{lcccc}
\hline \multicolumn{1}{c}{ Surrogate name } & $\begin{array}{c}\text { USGS } \\
\text { parameter code }\end{array}$ & N & \multicolumn{2}{c}{$\begin{array}{c}\text { Average percent recovery } \\
\text { (standard deviation) }\end{array}$} \\
\hline Diazinon-d10 & 91063 & 236 & 97.3 & $(13.1)$ \\
Terbuthylazin & 91064 & 236 & 106.2 & $(17.0)$ \\
HCH-d6, alpha & 91065 & 236 & 95.0 & $(13.1)$ \\
BDMC & 99835 & 206 & 86.4 & $(14.7)$ \\
\hline
\end{tabular}

\section{PESTICIDES IN SURFACE WATER}

Pesticides are introduced into the environment for a variety of reasons. About 70 to 80 percent of pesticide use is for agriculture production (Aspelin, 1994) and the remaining pesticide use generally is for forestry, transportation, and urban weed and insect control. Although pesticide use for non-agricultural purposes is large in some areas, agricultural-pesticide use provides the greatest potential for contamination of surface water (Larson and others, 1997, p. 135-177). In the State of Illinois, about 43 million pounds of herbicide and about 1.6 million pounds of insecticide were applied for the production of corn and soybeans in 1998 (Illinois Agricultural Statistics Service, 1999), the dominant crops in Illinois agriculture. Historically, herbicides are applied to 99 percent of the corn and 97 percent of the soybeans (Moyer and Cross, 1990, p. 7), a trend that continues in Illinois to the present (Michael Clark, Illinois Agricultural Statistics Service, oral commun., 2001). Additional pesticides are applied for other crops and for non-agricultural purposes.

Leonard (1990) summarized the four dominant factors that affect the delivery of pesticides to surface water from agricultural land. These factors are under the general categories of climate, soil characteristics, physical and chemical properties of the pesticide, and agricultural management practices. Climatic factors include amount, duration and intensity of rainfall, and timing of rainfall with respect to pesticide application. Soil characteristics include soil pesticide leaching potential, surface crusting and compaction, antecedent moisture conditions, slope, and extent of soil compaction and stability. The physical and chemical properties include solubility, acid/base neutralization properties, sorption potential, and persistence. Included in agricultural management practices are application rate and method, tillage practices, cropresidue management, use of vegetative buffer strips, and irrigation practices. For most streams and reservoirs downstream of agricultural areas, runoff from agricultural fields is the primary source of pesticides. However, pesticides transported as runoff into receiving streams from an agricultural area generally only constitute a small fraction of the total pesticides applied to land and crops. The fate of most agricultural pesticides is the following: transformation to other compounds or minerals which change the chemical structure; phase-transfer processes, which affect its movement between water, biota, suspended sediments, bed sediments, and the atmosphere; and movement into ground water (Larson and others, 1997, p. 227-233).

Laboratory analyses at the NWQL were done for 88 target pesticides and selected transformation products from schedules 2010 and 2051 (table 7). The 1996-98 data collection includes 258 samples for schedule 2010 and 233 samples for schedule 2051. Schedule 2010 and 2051 pesticides were detected above the MDL for only 31 of the 88 target pesticides. Thus, 57 of 88 target pesticides were either not present in any samples, or were present at concentrations below their respective MDL. Most of the pesticide detections (23 of 31) were of herbicides and the remaining 
detections ( 8 of 31 ) were of insecticides. Analyses also were performed at the OGRL for 9 herbicide transformation products on 34 samples collected in 1998 (table 8). The herbicide transformation product deethylatrazine, which is included in schedule 2010 , also was measured during the entire 1996-98 datacollection period, in addition to the 1998 analyses at OGRL. The nine target herbicide transformation products were detected with varying frequency at concentrations above their respective MDL.

The occurrence frequency of pesticide and pesticide transformation product detections for the 1996-98 data-collection period is summarized in table 12 and discussed below. Also, the maximum concentration measured for each pesticide, along with the associated human- or aquatic-health standard or guideline, if available are shown in table 12 . The number and type of samples collected from each sample site are summarized in table 1. About 56 percent of the samples were collected at two sites, the Sangamon River at Monticello and the La Moine River at Colmar. About 33 percent of the samples were from the main stem of the Illinois River, the other sites account for the remaining 11 percent of the sampling activity. The sampling frequency at the intensive sample sites for the months of October to February generally was once every 4 weeks. The sampling frequency was increased during the months of March through September in order to document changes in water quality during the growing season. During the growing season, Illinois River samples generally were collected every 2 weeks, while samples on the La Moine River at Colmar and the Sangamon River at Monticello generally were collected weekly.

Additional samples also were collected during periods of high streamflow, regardless of month. All the schedule 2010 and 2051 pesticide concentration data have been published previously in the annual USGS Water Resources Data reports for the State of Illinois (Wicker and others, 1997, 1998; LaTour and others, 1999).

\section{Pesticide Concentrations}

Atrazine and metolachlor were detected in 100 percent of the samples and at all sample sites. Various other herbicides had a high rate of detection, including (with percentage of detections): cyanazine (97 percent), prometon (93 percent), acetochlor (81 percent), simazine (78 percent), alachlor ( 74 percent) and bentazon ( 59 percent). The herbicides $2,4-\mathrm{D}$, diuron, metribuzin, pendimethalin, tebuthiuron, and trifluralin were detected at rates varying from 23 to 37 percent of the samples. The insecticides chlorpyrifos and diazinon were detected in 32 percent and 37 percent of samples, respectively. The remaining detected pesticides were found in less than 20 percent of the samples. Nearly all the frequently detected pesticides in the water-quality samples belong to either the triazine- or the chloroacetanilide-class of herbicides. Triazine-class herbicides detected in more than 75 percent of water-quality samples include atrazine, cyanazine, simazine, and prometon. Chloroacetanilideclass herbicides detected in more than half of waterquality samples include metolachlor, acetochlor, and alachlor. In general, the triazine-class herbicides have half-lives of 30 to 60 days, and degrade more slowly than the chloroacetanilide-class herbicides, which have typical half-lives of 15 to 30 days.

The effect of pesticides on water quality usually are evaluated by comparing the concentration of pesticides in an environmental sample to the concentrations that have been determined to have an adverse effect on humans, aquatic-based organisms, or other beneficial uses of water. The determinations of what constitutes an adverse concentration generally are made by Federal and State regulatory and scientific agencies, and usually are based on laboratory and field experiments that document the effect of a single pesticide on specific water-quality aspects. Most such determinations are made in the laboratory, where the responses of a single species of test organisms to specific pesticide concentrations are documented. To a lesser extent, adverse concentrations also are determined at the field scale, where the responses of multiple test organisms to specific pesticide concentrations are documented in an artificial ecosystem. Most of these studies do not consider the effect of exposure to more than one pesticide at a time. Although this is a substantial limitation, such an approach facilitates the establishment of Federal and State regulatory standards and guidelines, and also provides a framework within which to compare the conditions of different surface-water systems. 
Table 12. Summary of pesticides, herbicide transformation products, and water-quality standards in the lower Illinois River Basin, 1996-98

[U.S. Geological Survey, 2000b; HH, human health standard or guideline; AQCR, aquatic-life criteria; HH source: MCL, U.S. Environmental Protection Agency (USEPA) maximum contaminant level; HAL, health advisory level; RSD, risk specific dose. AQCR source: $\mathrm{FCH}$, USEPA freshwater value; CAN, Canadian water-quality criteria; CAN-int, Canadian interim water-quality criteria; GRL, Great Lakes water-quality criteria; N, number of detections; $\mu \mathrm{g} / \mathrm{L}$, micrograms per liter; N/A, not available]

\begin{tabular}{|c|c|c|c|c|c|c|c|}
\hline & $\mathbf{N}$ & $\begin{array}{c}\text { Percentage } \\
\text { of } \\
\text { detections }\end{array}$ & $\begin{array}{c}\text { Maximum } \\
\text { concentration } \\
(\mu \mathrm{g} / \mathrm{L})\end{array}$ & $\begin{array}{c}\text { HH } \\
(\mu \mathrm{g} / \mathrm{L})\end{array}$ & $\begin{array}{l}\text { AOCR } \\
(\mu g / L)\end{array}$ & $\begin{array}{c}\text { HH } \\
\text { source }\end{array}$ & $\begin{array}{l}\text { AOCR } \\
\text { source }\end{array}$ \\
\hline Acetochlor & 210 & 81 & 12 & N/A & N/A & N/A & $\mathrm{N} / \mathrm{A}$ \\
\hline Acifluorfen & 19 & 8 & .48 & 10 & N/A & RSD5 & N/A \\
\hline Alachlor & 191 & 74 & .93 & 2 & N/A & MCL & N/A \\
\hline Bentazon & 138 & 59 & 1.6 & 200 & N/A & HAL & N/A \\
\hline Bromoxynil & 5 & 2 & .14 & N/A & 5 & N/A & $\mathrm{CAN}$ \\
\hline Butylate & 27 & 10 & .09 & 350 & N/A & HAL & N/A \\
\hline Carbaryl & 21 & 8 & .12 & 700 & .2 & HAL & $\mathrm{CAN}$ \\
\hline Carbofuran & 39 & 15 & 1 & 40 & 1.8 & MCL & $\mathrm{CAN}$ \\
\hline Dicamba & 20 & 9 & .79 & 200 & 10 & HAL & CAN-int \\
\hline Dieldrin & 32 & 12 & .02 & .02 & .056 & RSD5 & $\mathrm{FCH}$ \\
\hline Diuron & 63 & 27 & .32 & 10 & N/A & HAL & N/A \\
\hline EPTC & 48 & 19 & .023 & N/A & N/A & N/A & N/A \\
\hline Fonofos & 6 & 2 & .01 & 10 & N/A & HAL & N/A \\
\hline Malathion & 8 & 3 & .02 & 200 & .1 & HAL & $\mathrm{FCH}$ \\
\hline Metolachlor & 258 & 100 & 20 & 70 & 7.8 & HAL & CAN-int \\
\hline Metribuzin & 92 & 37 & .6 & 100 & 1 & HAL & CAN-int \\
\hline Pendimethalin & 59 & 23 & .23 & N/A & N/A & N/A & N/A \\
\hline Prometon & 240 & 93 & .12 & 100 & N/A & HAL & N/A \\
\hline 2,4-D & 73 & 31 & 7.3 & 70 & 4 & $\mathrm{MCL}$ & $\mathrm{CAN}$ \\
\hline \multicolumn{8}{|c|}{ Herbicide transformation products } \\
\hline Acetochlor ESA & 32 & 94 & 2.58 & & & & \\
\hline Acetochlor OXA & 20 & 59 & 1.71 & & & & \\
\hline Alachlor ESA & 31 & 91 & 1.04 & & & & \\
\hline Alachlor OXA & 1 & 3 & .25 & & & & \\
\hline Cyanazine amide (CAM) & 20 & 59 & .82 & & & & \\
\hline Deethylatrazine (DEA) & 292 & 100 & 1.63 & & & & \\
\hline Deisopropylatrazine (DIA) & 28 & 82 & .74 & & & & \\
\hline Metolachlor ESA & 33 & 97 & 6.14 & & & & \\
\hline Metolachlor OXA & 25 & 74 & 1.52 & & & & \\
\hline \multicolumn{8}{|c|}{ Schedule $2010=258$ samples } \\
\hline \multicolumn{8}{|c|}{$\begin{array}{l}\text { Schedule } 2051=233 \text { samples } \\
\text { Herbicide transformation products }=34 \text { samples (except deethylatrazine (DEA), which is } 292 \text { samples) }\end{array}$} \\
\hline
\end{tabular}


Detected pesticide concentrations in the surfacewater samples were compared to two groups of published water-quality standards and guidelines, the human health $(\mathrm{HH})$ standard or guideline and the aquatic-life criteria (AQCR). Human health standards or guidelines are both enforceable and non-enforceable criteria related to the protection of human health (table 12). The AQCR are non-enforceable guidelines related to the protection of aquatic life or wildlife (table 12). Only the HH and AQCR of pesticides that were detected in the study area during the 1996-98 datacollection period are considered in this report. The $\mathrm{HH}$ is subdivided into three types, based on the source of the HH concentration value: (1) the U.S.

Environmental Protection Agency (USEPA) drinkingwater maximum contaminant level (MCL) standard, (2) the health advisory level (HAL), and (3) the risk specific dose (RSD). The MCL standard is an enforceable maximum concentration of a specific pesticide in drinking water promulgated under the Safe Drinking Water Act (U.S. Environmental Protection Agency, 1999a). The HAL is a non-enforceable drinking-water guideline that provides a pesticide concentration below which there is no expectation of adverse non-carcinogenic effects over a lifetime of exposure, with a margin of safety considered (U.S. Environmental Protection Agency, 1988). The RSD, which also is a non-enforceable guideline, is the pesticide concentration that is associated with a specified cancer risk level, under certain exposure conditions, and over a lifetime of consumption (U.S. Environmental Protection Agency, 1989).

Aquatic-life criteria are subdivided into four types, based on the source of the criteria: (1) the USEPA freshwater value ( $\mathrm{FCH}),(2)$ the Canadian water-quality criteria (CAN), (3) the Canadian-interim water-quality criteria (CAN-int), and (4) the Great Lakes water-quality criteria (GRL). These aquatic criteria all are non-enforceable guidelines related to the protection of wildlife and/or aquatic organisms in freshwater. The FCH specifies a pesticide concentration below that there should be no unacceptable effects on aquatic organisms during a period of short-term exposure (for acute criteria) or chronic exposure (for chronic criteria) (U.S. Environmental Protection Agency, 1999b). The CAN guideline is the maximum concentration of a pesticide at which there is no expectation of any long-term negative effect to aquatic life (Canadian Council of Resource and Environment Ministers, 1997). The CAN-int guideline is the same as the CAN, except the CAN-int guideline is issued when data are limited (Canadian Council of Resource and Environment Ministers, 1997). Both the CAN and CAN-int guidelines consider all components of the aquatic ecosystem (algae, macrophytes, invertebrates, and fish), if sufficient data are available. The GRL criteria specify the minimum level of water quality desired in the boundary waters of the Great Lakes system and were not intended to preclude the establishment of more stringent requirements (International Joint Commission, 1999). The HH and AQCR standards, guidelines, and derivations for pesticides observed in this study, in addition to other pesticides and chemicals, have been summarized by Larson and others (1999).

Two herbicides, atrazine and cyanazine, were detected at concentrations exceeding both the USEPA clean drinking-water standard and the Canadian aquatic-life criteria. The herbicides metolachlor and 2,4-D and the insecticides chlorpyrifos and diazinon were detected at concentrations exceeding the aquaticlife criteria. The pesticides alachlor, carbaryl, carbofuran, metribuzin, and triallate were within 50 percent or more of either their associated HH or AQCR standard or guideline, but did not exceed either the standard or guideline. Detailed information about the pesticides detected in this study, including trade names, regulatory status, physical properties, toxicological effects, and environmental fate, is summarized by the Extension Toxicology Network (Extoxnet, 2000), a Web site cooperatively maintained by five universities. Some of the detected pesticides (most notably atrazine, cyanazine, acetochlor, and alachlor) are classified by the USEPA as restricted-use pesticides, and may be purchased and used only by certified applicators (U.S. Environmental Protection Agency, 2000). Other detected pesticides are classified as general-use pesticides, and their sales and use is less regulated (U.S. Environmental Protection Agency, 2000).

In many of the graphs that follow in this report, pesticide concentrations are shown with standard boxplots. Standard boxplots show data from the $10^{\text {th }}$ to the $90^{\text {th }}$ percentile. The upper and lower bounds of the box represent the $75^{\text {th }}$ and $25^{\text {th }}$ percentile limits of the data, respectively, and the median data value is between these two percentiles. The upper and lower boxplot 
whiskers represent the $90^{\text {th }}$ and $10^{\text {th }}$ percentile limits of the data, respectively. A sample boxplot is shown in figure 4. A pesticide concentration is included if the compound was detected by NWQL above the pesticide MDL or if the pesticide concentration was estimated. Otherwise, the concentration value is not considered.

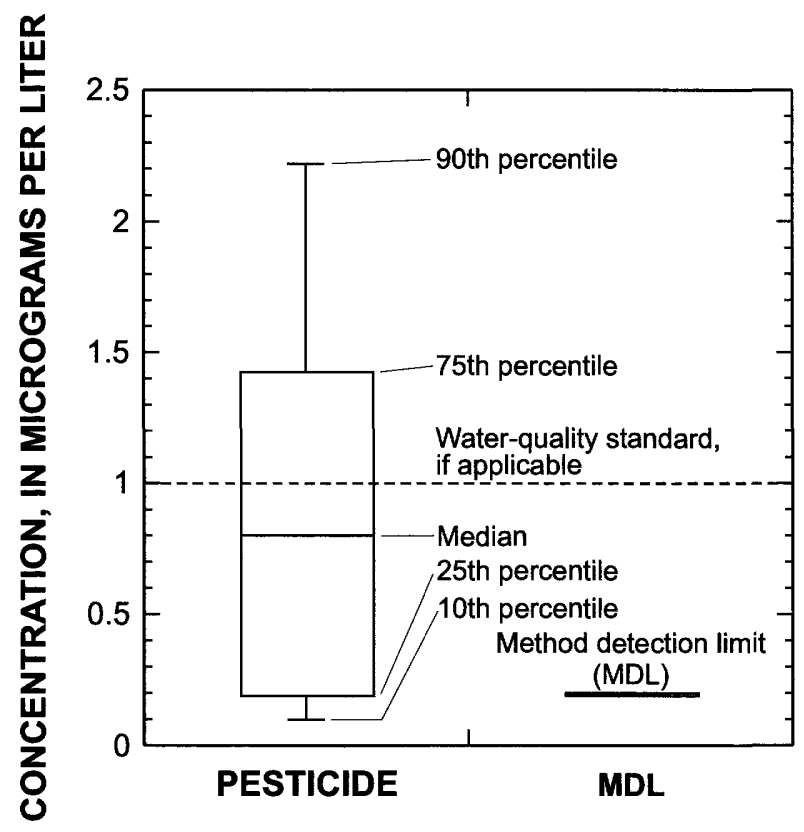

Figure 4. Sample boxplot of pesticide concentration data.

\section{Acetochlor}

Acetochlor is a restricted-use herbicide and belongs to the chloroacetanilide class. Acetochlor has conditional authorization for use in the United States. This conditional authorization allows for automatic cancellation based on three distinct criteria. Specifically, cancellation may occur if use of various alternative corn herbicides is not reduced by a specified amount or if ground-water or surface-water contamination occurs. Surface-water contamination is defined, in part, as an annual average concentration in excess of $2 \mu \mathrm{g} / \mathrm{L}$ in a community water-supply system (U.S. Environmental Protection Agency, 1994).

Acetochlor is applied pre-emergent on cropland and used for control of most annual grasses and certain broadleaf weeds (Extoxnet, 2000). Acetochlor is the third most frequently used pesticide in the study area. The use of acetochlor remained fairly steady during 1996-98, and application averaged about 975 tons per year in the study area.
Acetochlor was detected in 81 percent of the samples at an average concentration of $0.57 \mu \mathrm{g} / \mathrm{L}$ and a median concentration of $0.05 \mu \mathrm{g} / \mathrm{L}$ (fig. 5). The maximum concentration was $12 \mu \mathrm{g} / \mathrm{L}$, which was observed at the La Moine River at Colmar during a high-flow condition (11-percent exceedance probability) in May 1998. (Exceedance probability is a statistical computation based on the historical streamflow record that measures the chance that a given flow will occur.) At the time of this report, there is no published human health or aquatic water-quality standard or guideline for acetochlor. Acetochlor concentrations increased from May to June during the 1996-98 data-collection period.

\section{Acifluorfen}

Acifluorfen is a general-use herbicide and belongs to the contact diphenolic ether class. Acifluorfen is used to control broadleaf weeds and grasses in soybeans, and can be applied before or after crop emergence (Extoxnet, 2000). The average use of acifluorfen in the study area during 1996-98 was about 14 tons per year. However, the application rate varied during this period, particularly from 1996 to 1997 , when the application rate more than doubled (table 5).

Acifluorfen was detected in 8 percent of samples at an average concentration of $0.09 \mu \mathrm{g} / \mathrm{L}$ and a median concentration of $0.05 \mu \mathrm{g} / \mathrm{L}$ (fig. 5). Nearly all detections were in June through August samples at the La Moine River at Colmar and the Sangamon River at Monticello, although the compound also was detected once $(0.04 \mu \mathrm{g} / \mathrm{L})$ at the Illinois River atValley City in June 1998. The maximum concentration was $0.48 \mu \mathrm{g} /$ $\mathrm{L}$ (RSD guideline is $10 \mu \mathrm{g} / \mathrm{L}$ ), which was observed at the La Moine River at Colmar during a high-flow condition (14-percent exceedance probability) in August 1998.

\section{Alachlor}

Alachlor is a restricted-use herbicide and belongs to the chloroacetanilde class. Alachlor is a selective herbicide used to control annual grasses and broadleaf weeds in field corn and soybeans (Extoxnet, 2000). Alachlor use in the study area declined from about 47 tons in 1996 to zero in 1998 (table 5). 


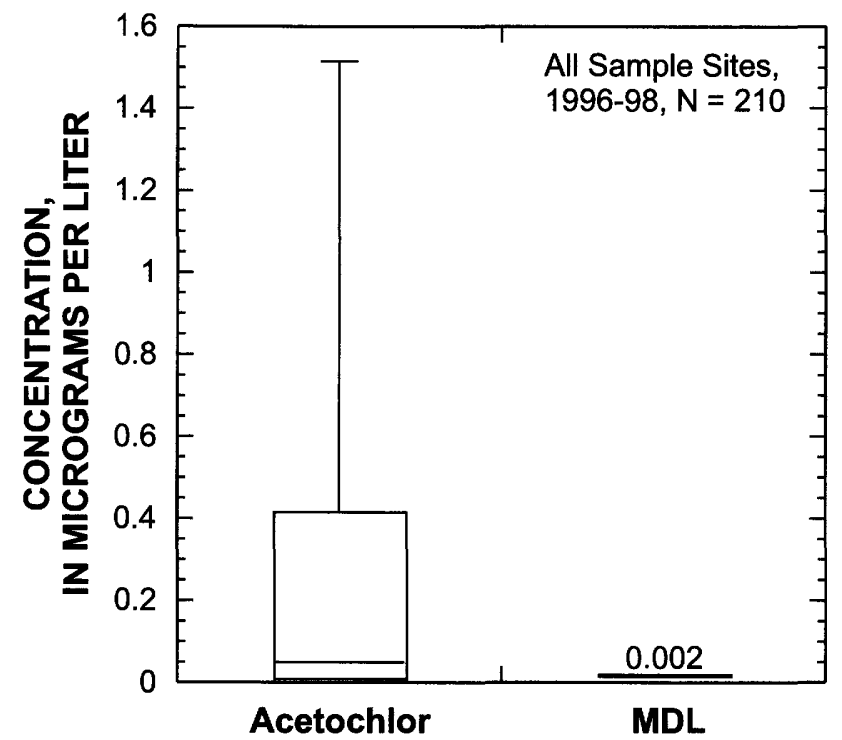

EXPLANATION

MDL, method detection limit

$\mathrm{N}$, number of samples
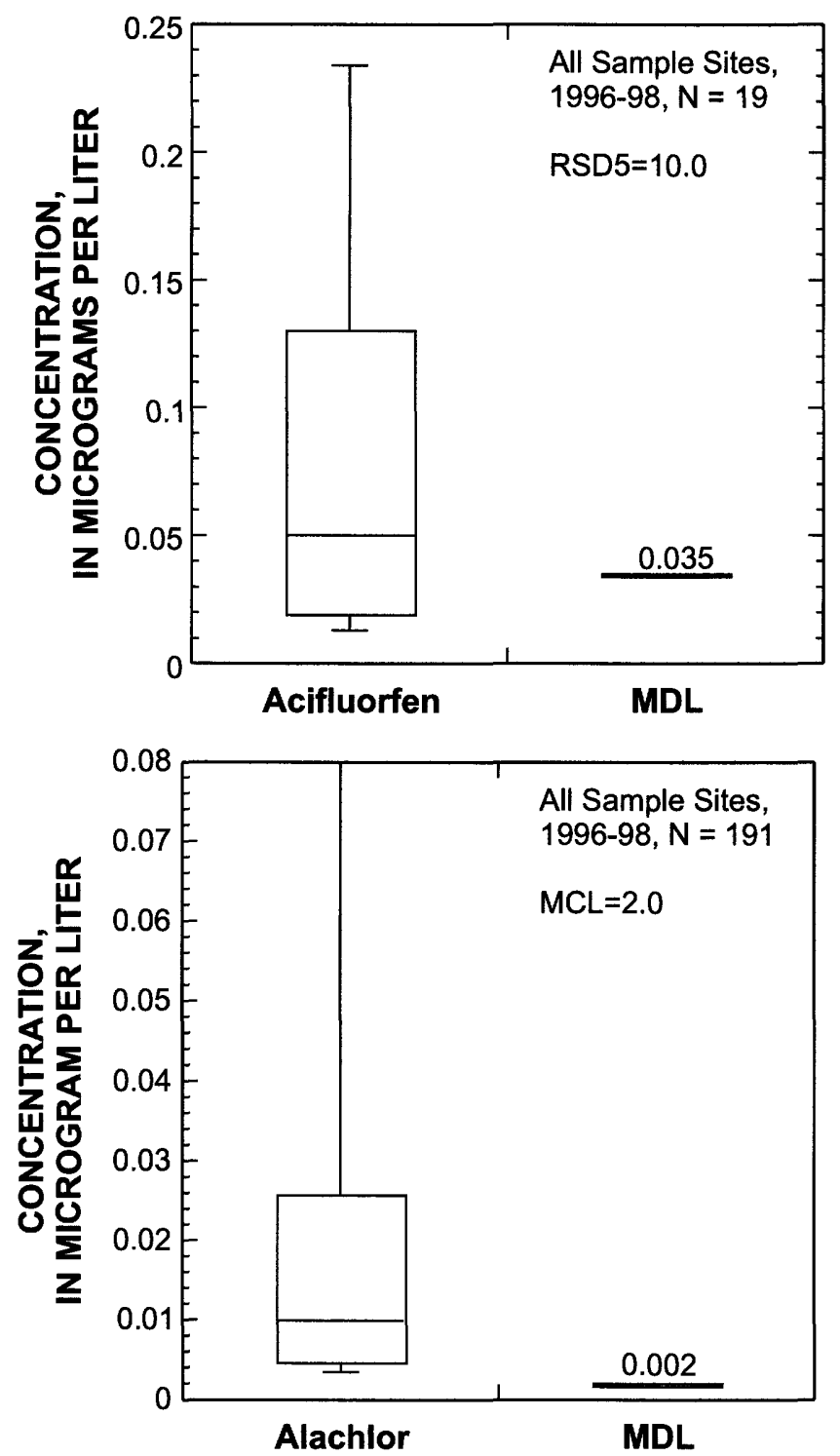

\section{EXPLANATION}

$M C L$, maximum contaminant level MDL, method detection limit

$\mathrm{N}$, number of samples

\section{EXPLANATION}

MDL, method detection limit

RSD5, risk specific dose

$\mathrm{N}$, number of samples

Figure 5. Concentrations of detected pesticides at all sample sites in the lower Illinois River Basin, 1996-98. (See figure 4 for explanation of boxplots.) 

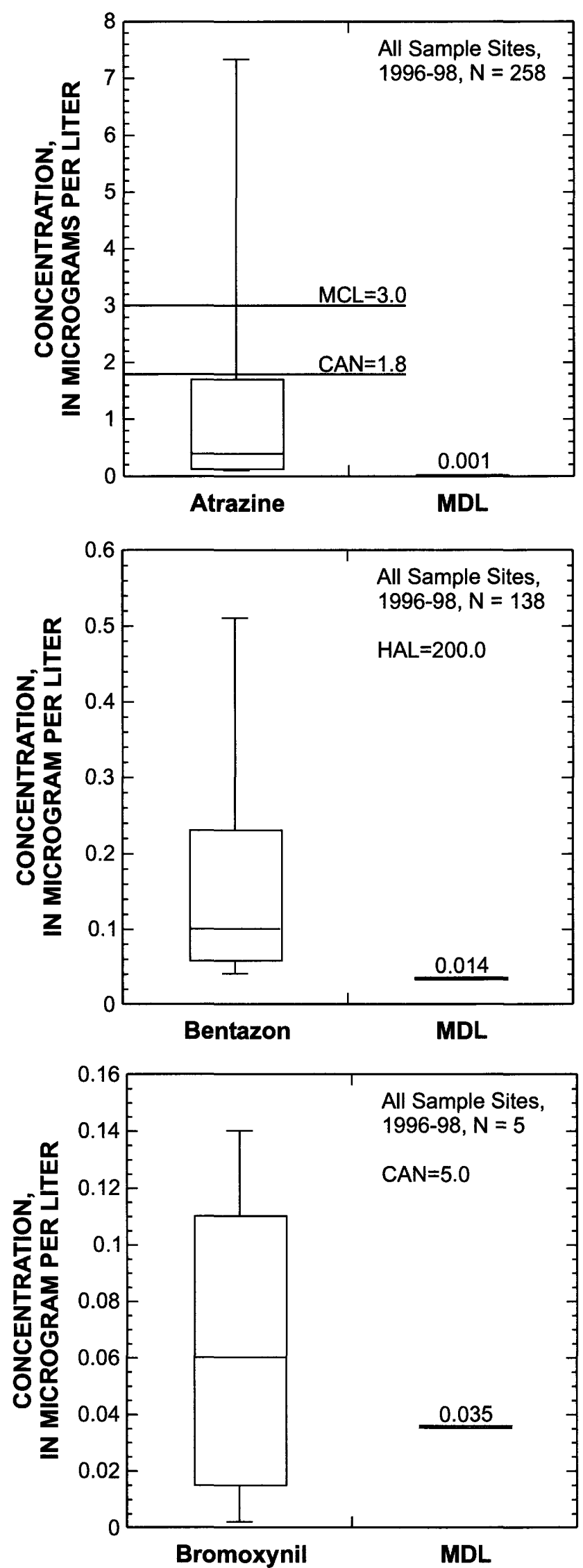

\section{EXPLANATION}

MCL, maximum contaminant level

MDL, method detection limit

CAN, Canadian water-quality criteria

$\mathrm{N}$, number of samples

\section{EXPLANATION}

MDL, method detection limit

HAL, health advisory level

$\mathrm{N}$, number of samples

\section{EXPLANATION}

MDL, method detection limit

CAN, Canadian water-quality criteria $\mathrm{N}$, number of samples

Figure 5. Concentrations of detected pesticides at all sample sites in the lower Illinois River Basin, 1996-98 - Continued. (See figure 4 for explanation of boxplots.) 


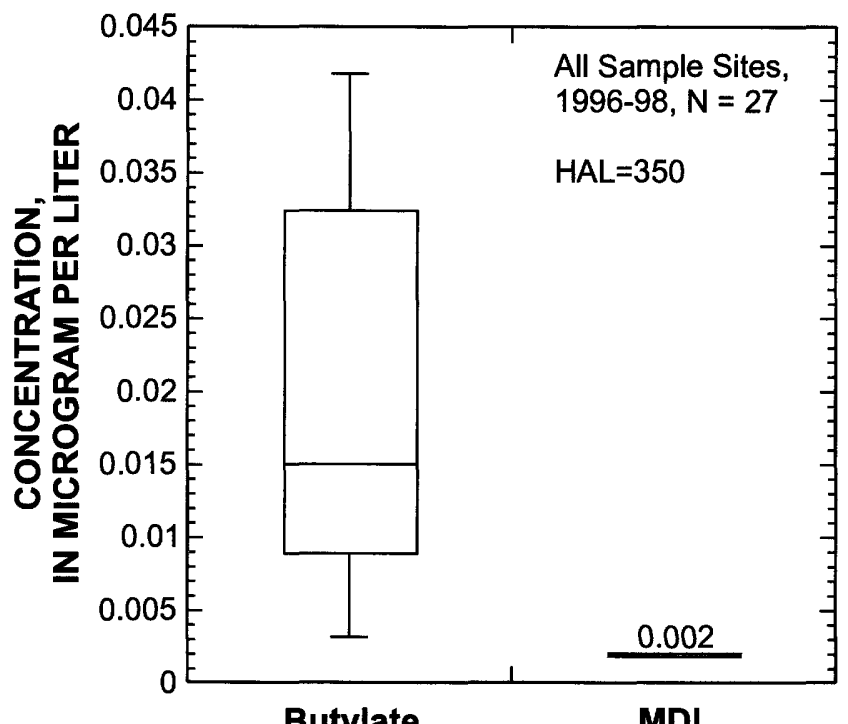

\section{EXPLANATION}

MDL, method detection limit

HAL, health advisory level

$\mathrm{N}$, number of samples

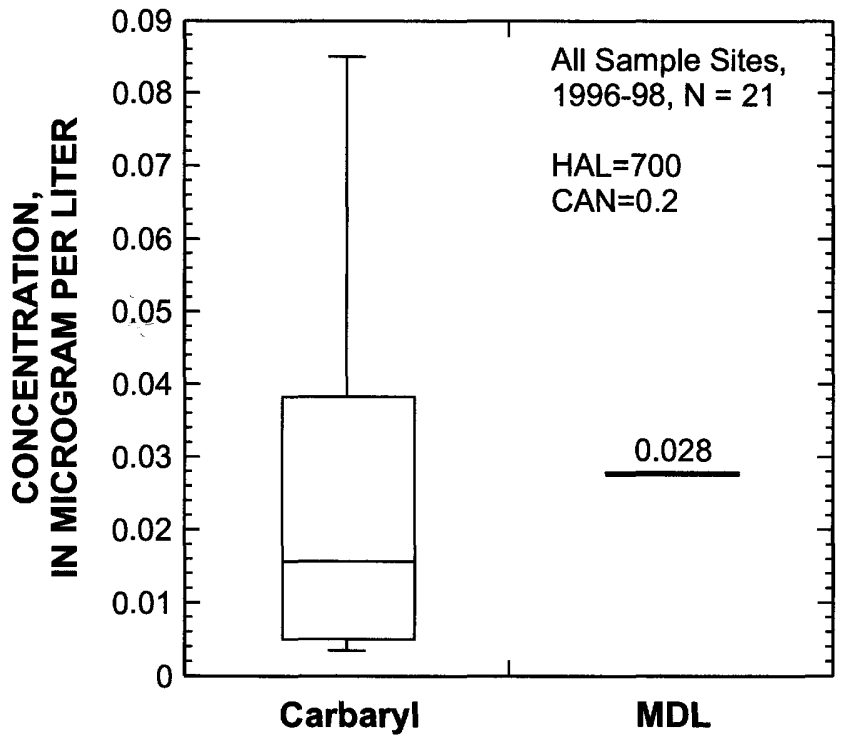

\section{EXPLANATION}

MDL, method detection limit

CAN, Canadian water-quality criteria

HAL, health advisory level

$\mathrm{N}$, number of samples

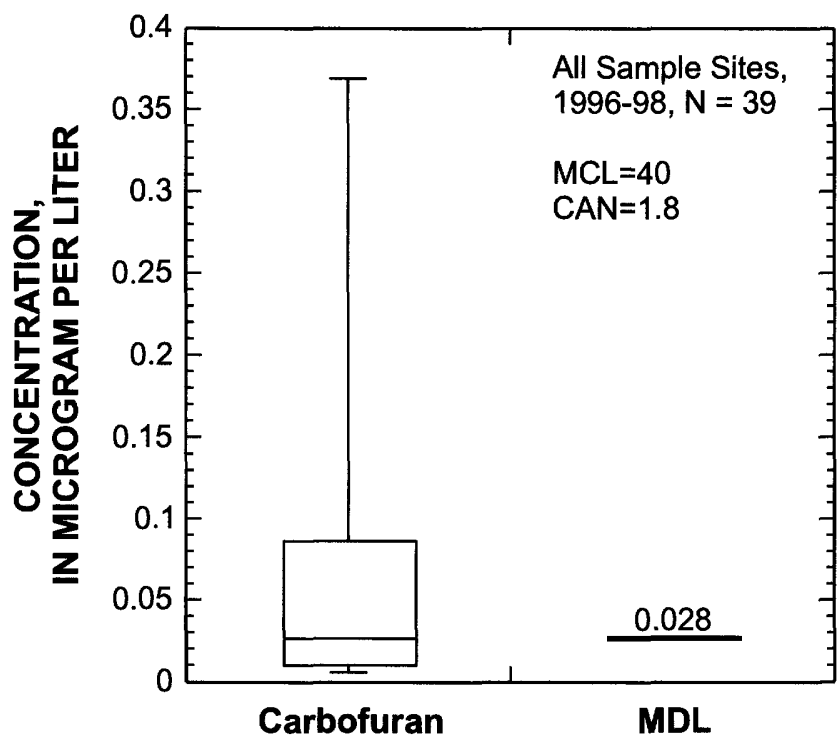

\section{EXPLANATION}

MCL, maximum contaminant level

MDL, method detection limit

CAN, Canadian water-quality criteria $\mathrm{N}$, number of samples

Figure 5. Concentrations of detected pesticides at all sample sites in the lower Illinois River Basin, 1996-98-Continued. (See figure 4 for explanation of boxplots.) 

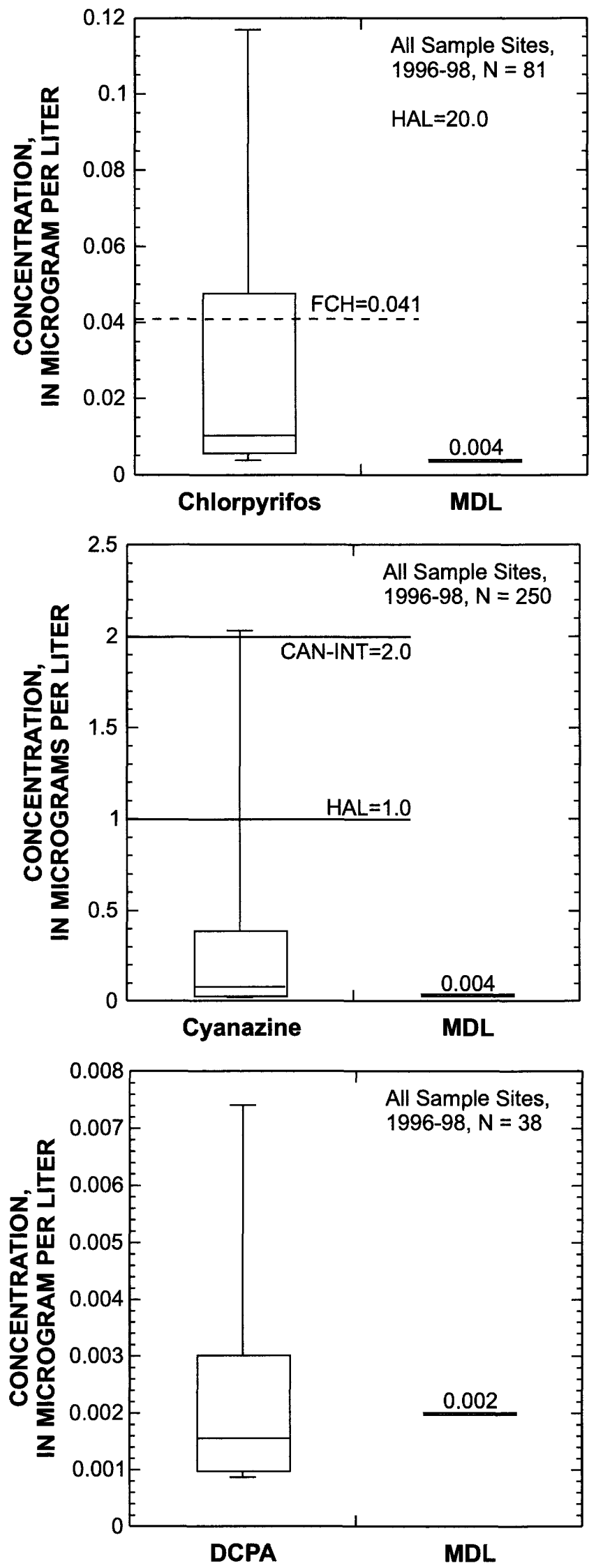

EXPLANATION

MDL, method detection limit

HAL, health advisory level

$\mathrm{FCH}$, freshwater value

$\mathrm{N}$, number of samples

\section{EXPLANATION}

MDL, method detection limit

CAN-INT, Canadian-interim water-quality criteria $\mathrm{HAL}$, health advisory level

$\mathrm{N}$, number of samples

\section{EXPLANATION}

MDL, method detection limit

$\mathrm{N}$, number of samples

Figure 5. Concentrations of detected pesticides at all sample sites in the lower Illinois River Basin, 1996-98-Continued. (See figure 4 for explanation of boxplots.) 


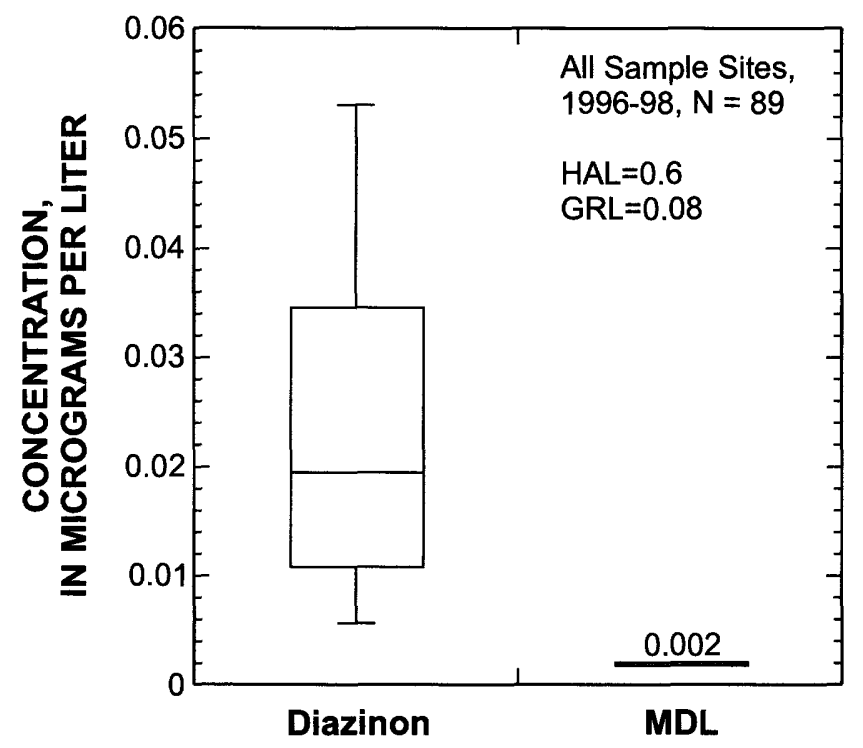

\section{EXPLANATION}

MDL, method detection limit

GRL, Great Lakes water-quality criteria

$H A L$, health advisory level

$\mathrm{N}$, number of samples

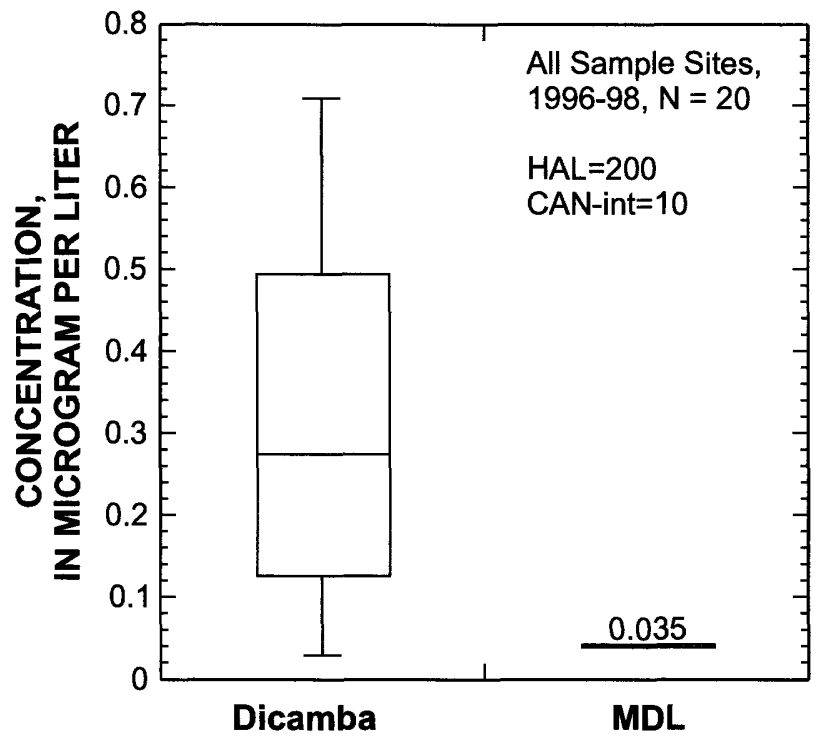

\section{EXPLANATION}

MDL, method detection limit

CAN-int, Canadian-interim water-quality criteria

$H A L$, health advisory level

$\mathrm{N}$, number of samples

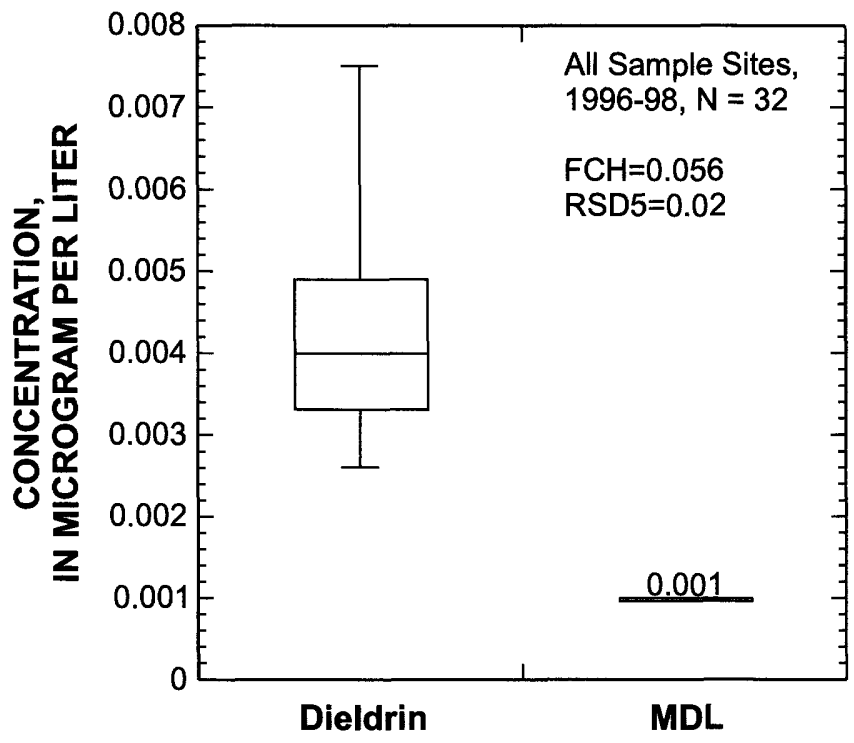

\section{EXPLANATION}

MDL, method detection limit

RSD5, risk specific dose

$\mathrm{FCH}$, freshwater value

$\mathrm{N}$, number of samples

Figure 5. Concentrations of detected pesticides at all sample sites in the lower Illinois River Basin, 1996-98-Continued. (See figure 4 for explanation of boxplots.) 


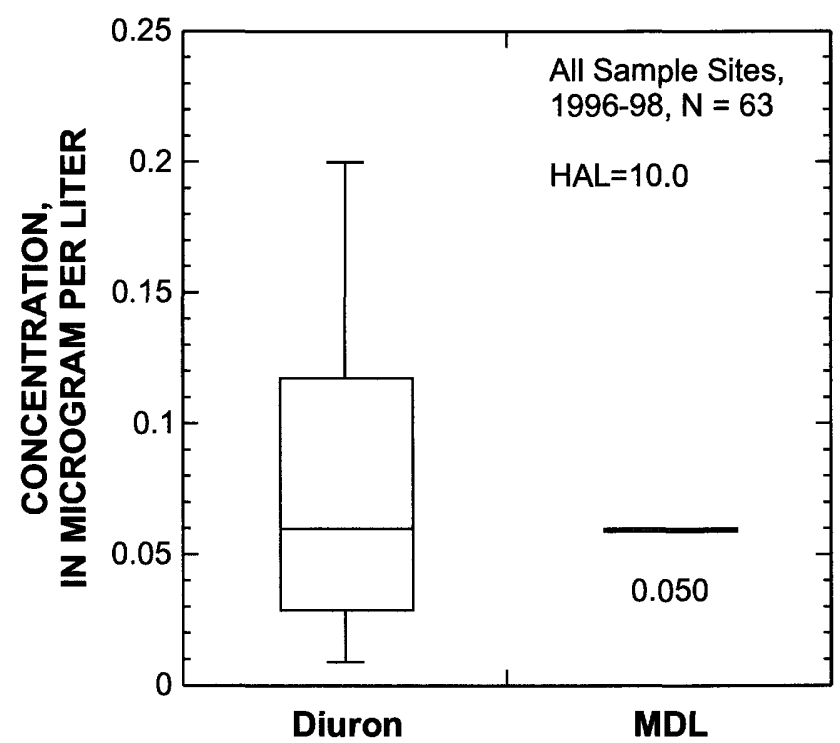

EXPLANATION

MDL, method detection limit

HAL, health advisory level

$\mathrm{N}$, number of samples

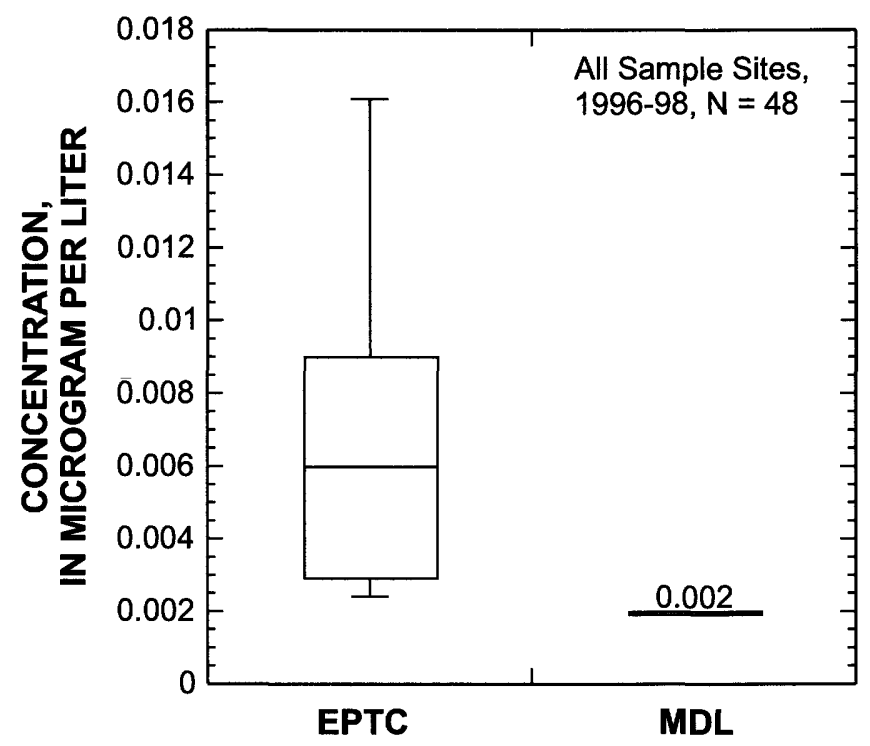

\section{EXPLANATION}

MDL, method detection limit

$\mathrm{N}$, number of samples

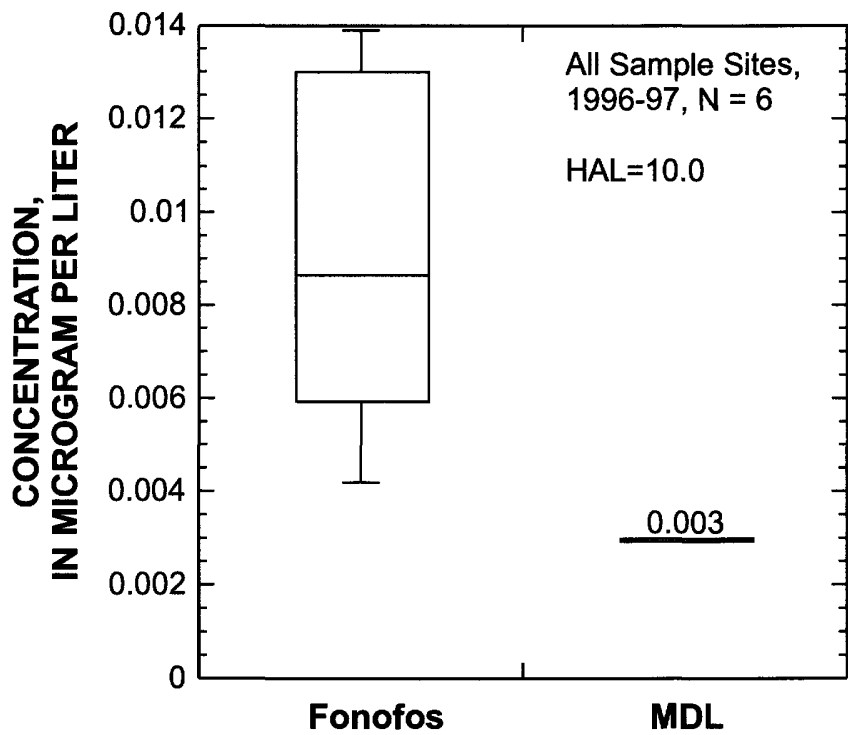

\section{EXPLANATION}

MDL, method detection limit HAL, health advisory level

$\mathrm{N}$, number of samples

Figure 5. Concentrations of detected pesticides at all sample sites in the lower Illinois River Basin, 1996-98 - Continued. (See figure 4 for explanation of boxplots.) 

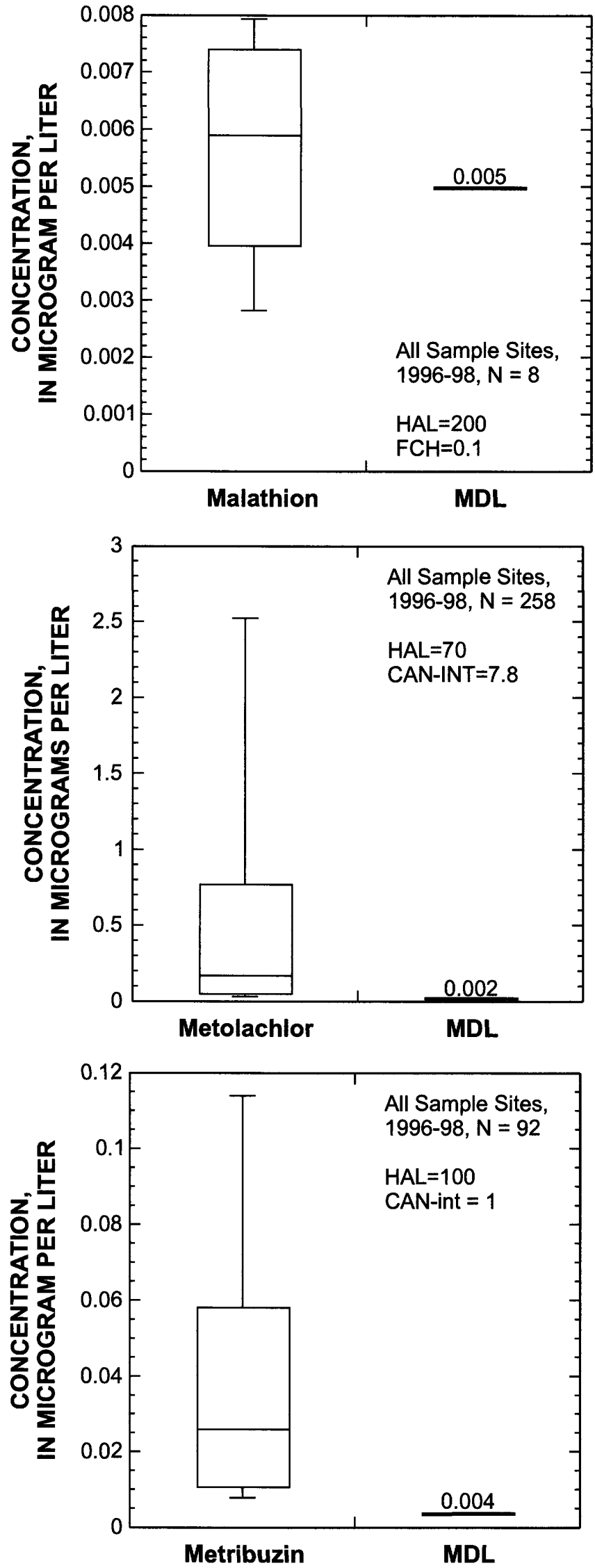

\section{EXPLANATION}

MDL, method detection limit

HAL, health advisory level

$\mathrm{FCH}$, freshwater value

$\mathrm{N}$, number of samples

\section{EXPLANATION}

MDL, method detection limit

CAN-INT, Canadian-interim water-quality criteria

HAL, health advisory level

$\mathrm{N}$, number of samples

\section{EXPLANATION}

MDL, method detection limit

CAN-int, Canadian-interim water-quality criteria

$H A L$, health advisory level

$\mathrm{N}$, number of samples

Figure 5. Concentrations of detected pesticides at all sample sites in the lower Illinois River Basin, 1996-98-Continued. (See figure 4 for explanation of boxplots.) 


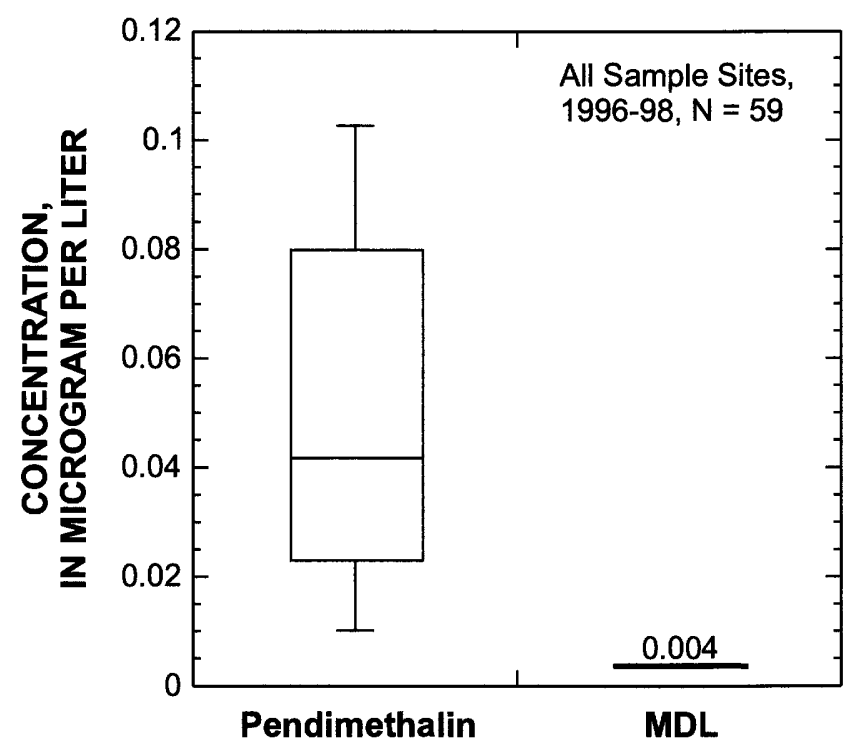

\section{EXPLANATION}

MDL, method detection limit

$\mathrm{N}$, number of samples

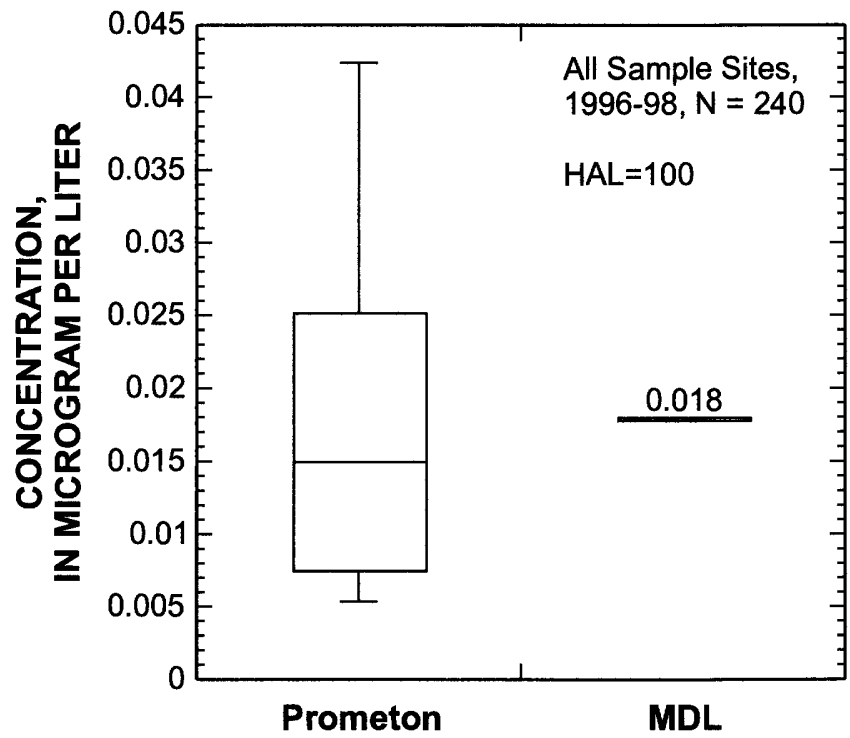

\section{EXPLANATION}

MDL, method detection limit $H A L$, health advisory level

$\mathrm{N}$, number of samples

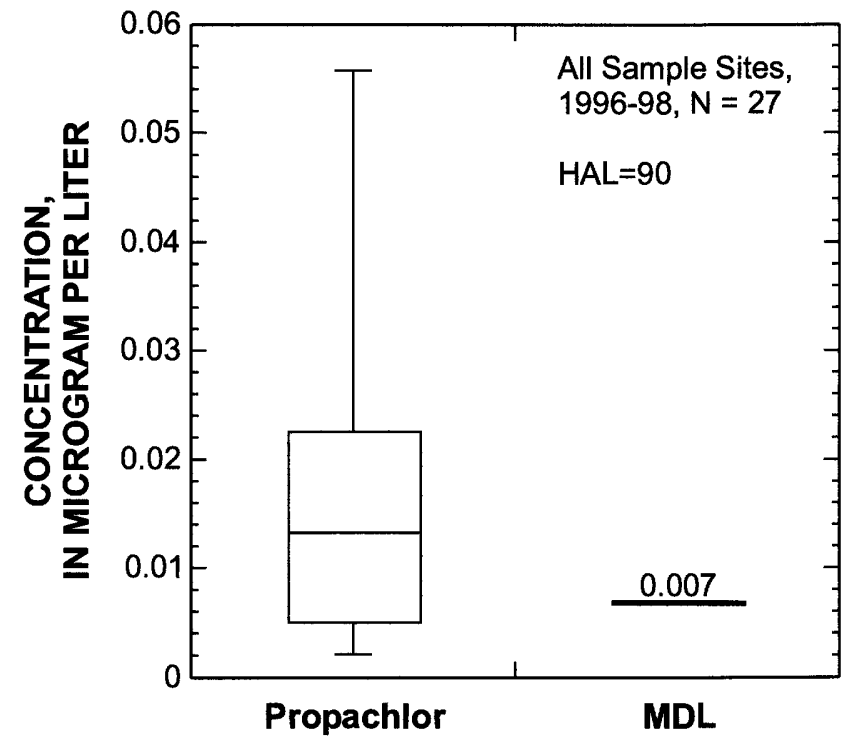

\section{EXPLANATION}

MDL, method detection limit $H A L$, health advisory level $\mathrm{N}$, number of samples

Figure 5. Concentrations of detected pesticides at all sample sites in the lower Illinois River Basin, 1996-98 - Continued. (See figure 4 for explanation of boxplots.) 


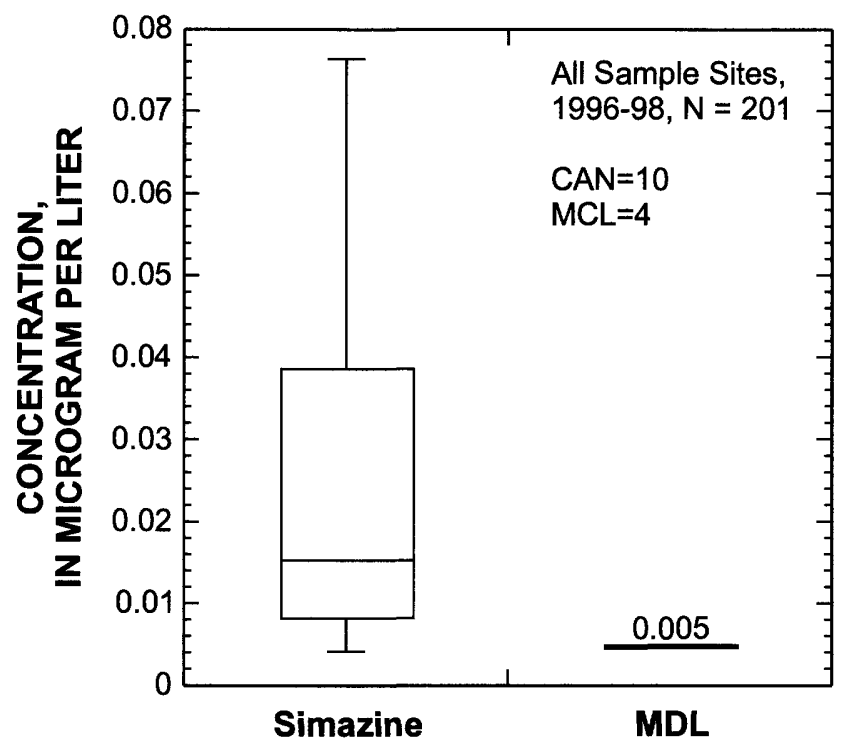

\section{EXPLANATION}

MCL, maximum contaminant level

MDL, method detection limit

CAN, Canadian water-quality criteria

$\mathrm{N}$, number of samples

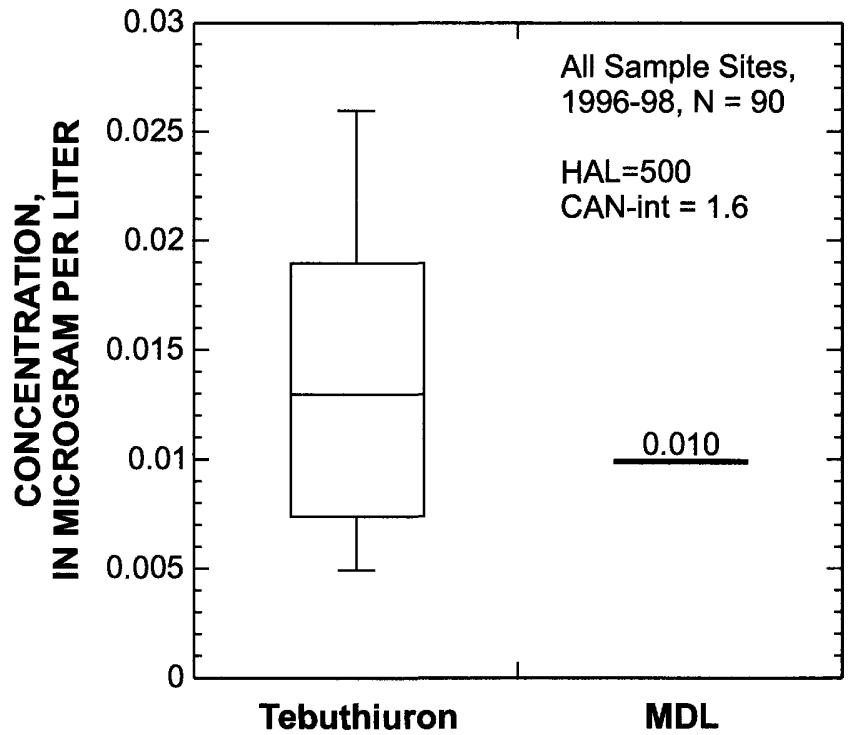

\section{EXPLANATION}

MDL, method detection limit

CAN-int, Canadian-interim water-quality criteria

$H A L$, health advisory level

$\mathrm{N}$, number of samples

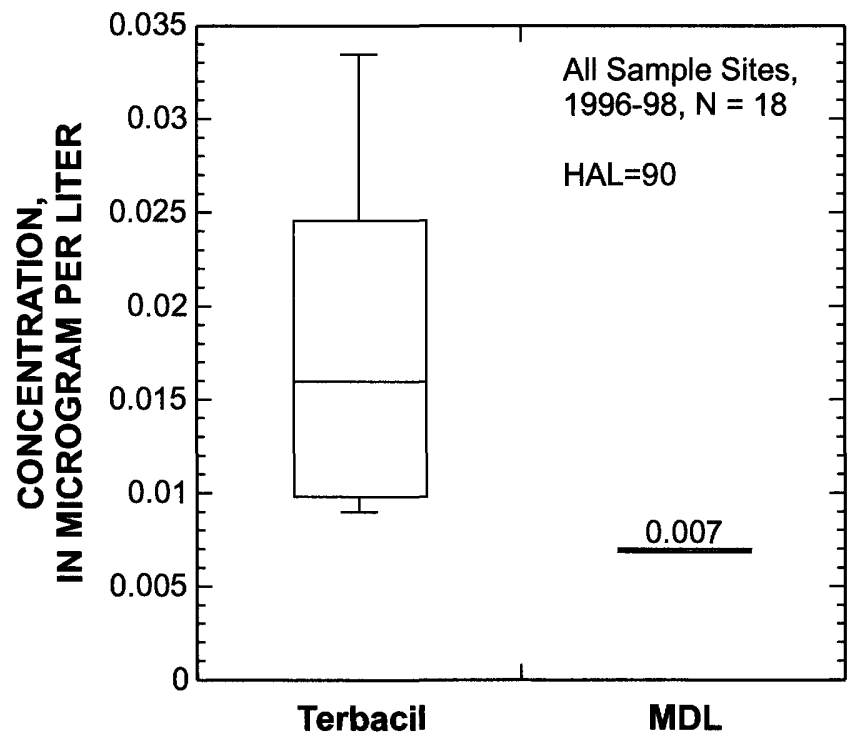

\section{EXPLANATION}

MDL, method detection limit

HAL, health advisory level

$\mathrm{N}$, number of samples

Figure 5. Concentrations of detected pesticides at all sample sites in the lower Illinois River Basin, 1996-98-Continued. (See figure 4 for explanation of boxplots.) 

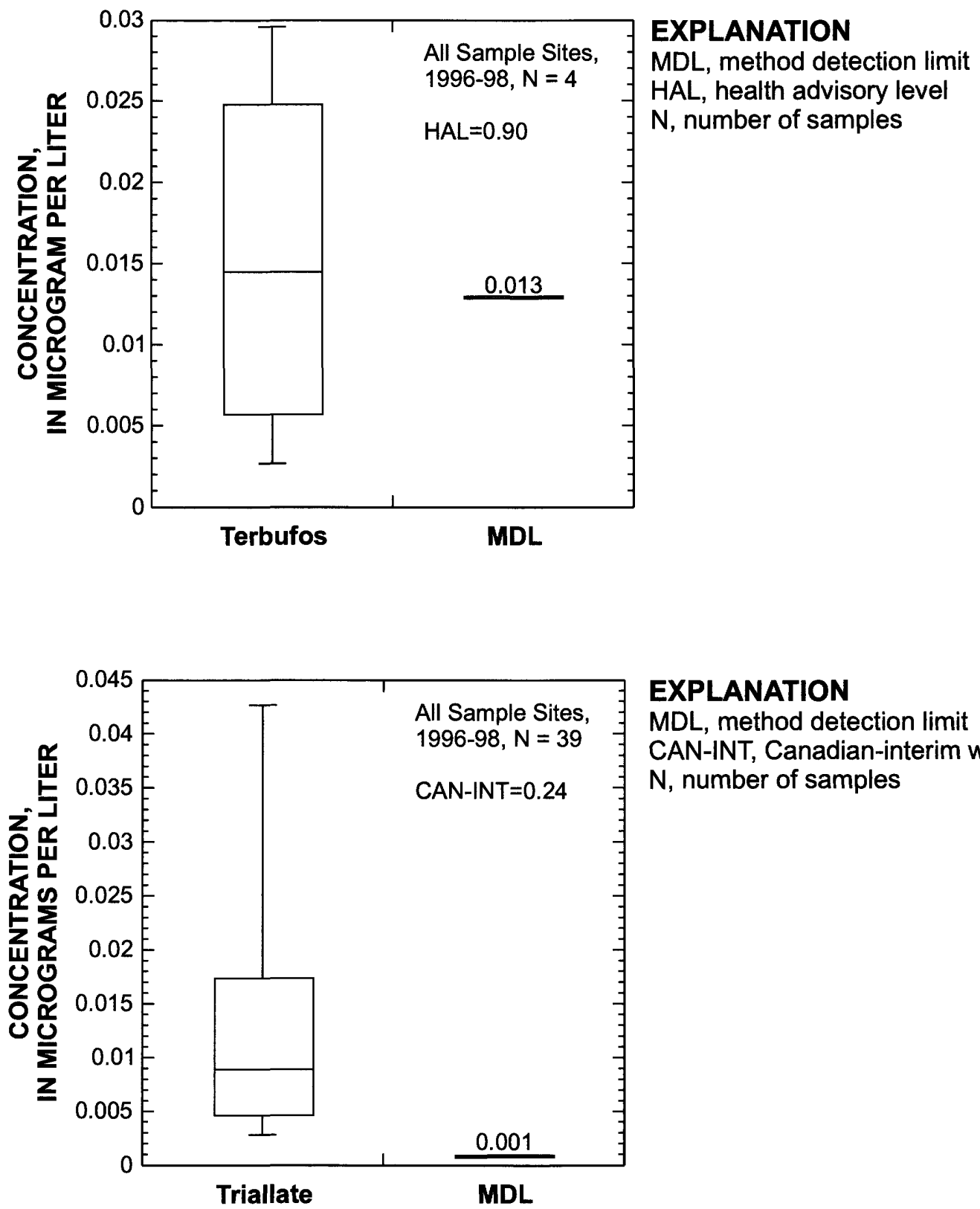

\section{EXPLANATION}

MDL, method detection limit

CAN-INT, Canadian-interim water-quality criteria $\mathrm{N}$, number of samples

Figure 5. Concentrations of detected pesticides at all sample sites in the lower Illinois River Basin, 1996-98-Continued. (See figure 4 for explanation of boxplots.) 


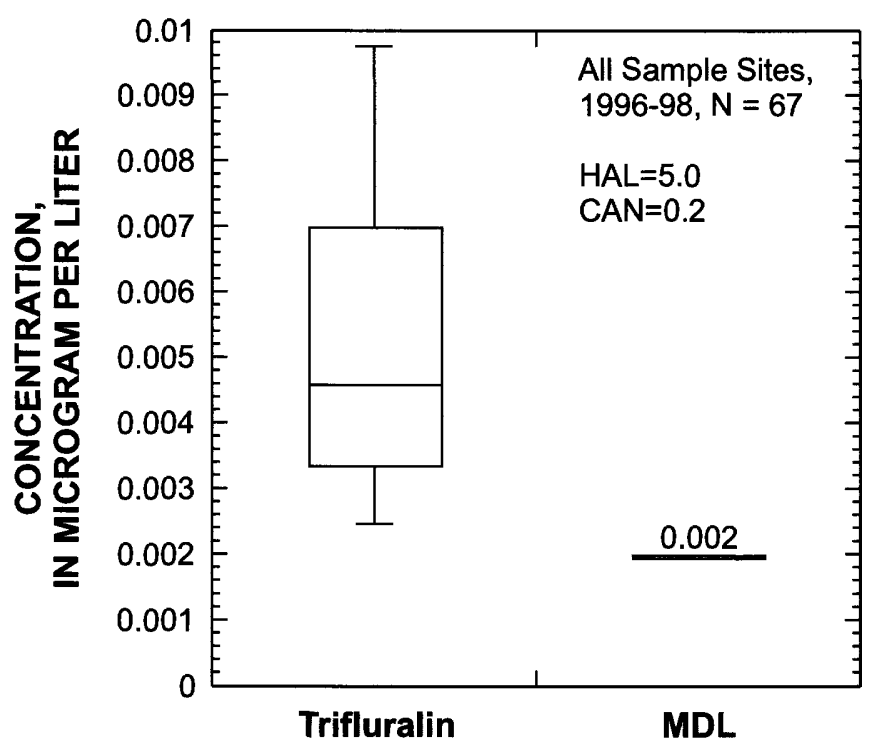

\section{EXPLANATION}

MDL, method detection limit

CAN, Canadian water-quality criteria

HAL, health advisory level

$\mathrm{N}$, number of samples

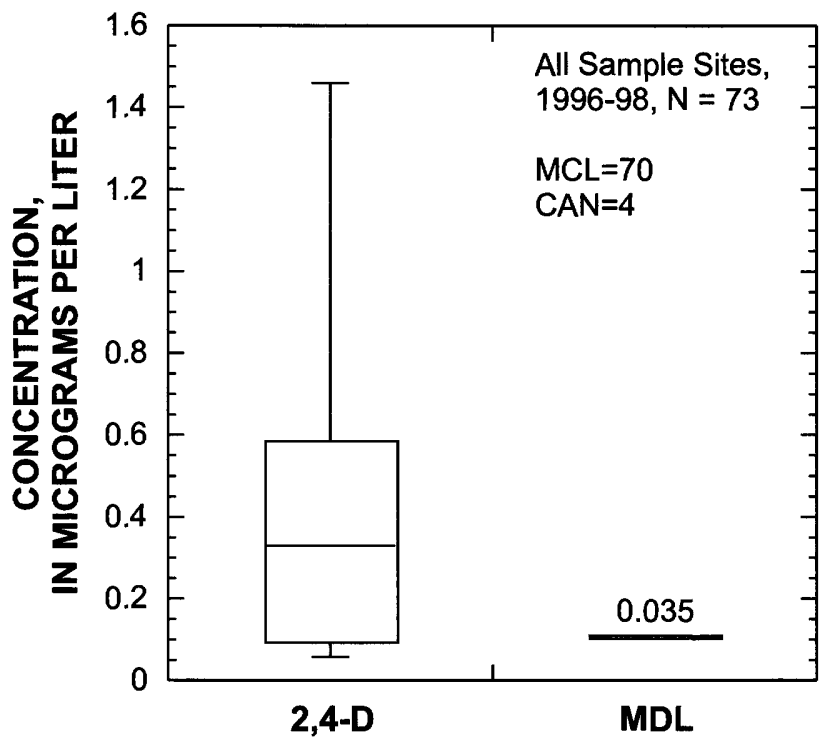

\section{EXPLANATION}

MCL, maximum contaminant level

MDL, method detection limit

CAN, Canadian water-quality criteria

$\mathrm{N}$, number of samples

Figure 5. Concentrations of detected pesticides at all sample sites in the lower Illinois River Basin, 1996-98 - Continued. (See figure 4 for explanation of boxplots.) 
Alachlor was detected in 74 percent of the samples at an average concentration of $0.33 \mu \mathrm{g} / \mathrm{L}$ and a median concentration of $0.01 \mu \mathrm{g} / \mathrm{L}$ (fig. 5). The maximum concentration was $0.93 \mu \mathrm{g} / \mathrm{L}$ (U.S. Environmental Protection Agency clean-water standard MCL is $2.0 \mu \mathrm{g} / \mathrm{L}$ ), which was observed during a high-flow condition (4-percent exceedance probability) in May 1997 at the La Moine River at Colmar. Although alachlor was applied in the study area in both 1996 and 1997, no alachlor was applied in 1998. However, alachlor generally persisted in water-quality samples at detectable but declining concentrations at all the intensive sites through July 1998.

\section{Atrazine}

Atrazine is a restricted-use herbicide and belongs to the triazine class. Atrazine is used primarily for the selective control of annual grasses and broadleaf weeds on corn, and as a non-selective herbicide on industrial land and on fallow land (Extoxnet, 2000). Atrazine had the highest use in the study area. Atrazine use remained fairly steady during 1996-98, averaging nearly 1,700 tons per year.

Atrazine was detected in 100 percent of samples at an average concentration of $3.1 \mu \mathrm{g} / \mathrm{L}$ and a median concentration of $0.40 \mu \mathrm{g} / \mathrm{L}$ (fig. 5). Atrazine concentrations exceeded the USEPA drinking-water standard of $3.0 \mu \mathrm{g} / \mathrm{L}$ on numerous occasions at all the intensive sample sites (the Illinois River at Ottawa, the Illinois River at Valley City, the La Moine River at Colmar, and the Sangamon River at Monticello). Further, the median atrazine concentration of the samples acquired in May and June exceeded $3.0 \mu \mathrm{g} / \mathrm{L}$ at all intensive sample sites. Almost without exception, the samples that exceeded the atrazine drinking-water standard were collected in May or June. About 56 percent of the samples from the Illinois River at Ottawa collected in the months of May and June exceeded the MCL for atrazine (fig. 6), and about 67 percent of these

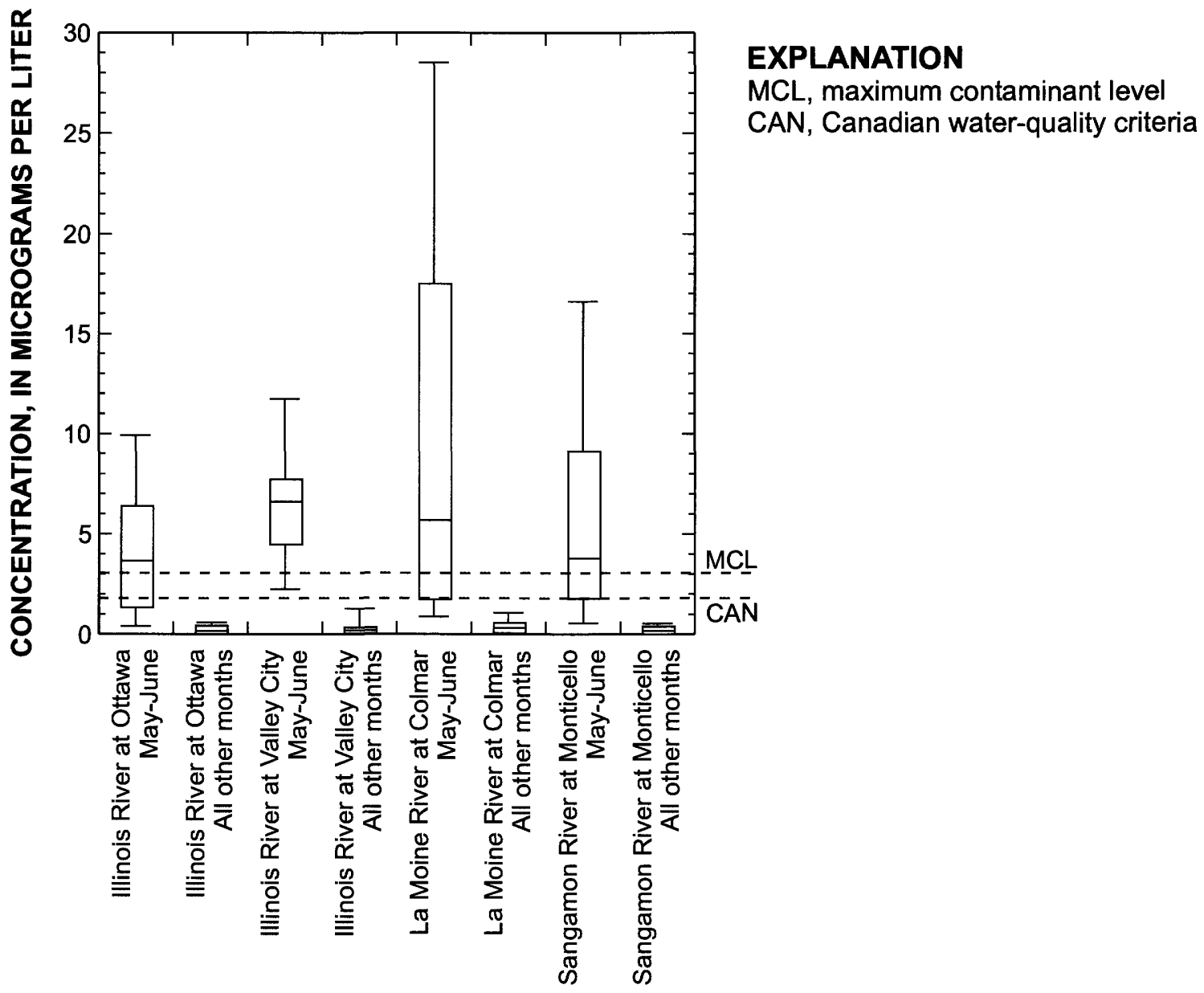

Figure 6. Comparison of atrazine concentrations at intensive sample sites, by season, lower Illinois River Basin, 1997-98. (See figure 4 for explanation of boxplots.) 
samples exceeded the AQCR guideline of $1.8 \mu \mathrm{g} / \mathrm{L}$. The maximum atrazine concentration at the Illinois River at Ottawa was observed in May 1997 during a high-flow condition (21-percent exceedance probability). About 83 percent of the water-quality samples collected from the Illinois River at Valley City during May and June exceeded the atrazine MCL standard (fig. 6), and 100 percent of these samples exceeded the AQCR guideline. Most of the high atrazine concentrations measured at Valley City that exceeded the MCL standard were between 7 and $8 \mu \mathrm{g} / \mathrm{L}$, although the maximum concentration was $20 \mu \mathrm{g} / \mathrm{L}$, observed in May 1996 during a high-flow condition (5-percent exceedance probability).

The NWQL reports atrazine concentrations above $20 \mu \mathrm{g} / \mathrm{L}$ as estimated because they exceed the highest calibration point used in the GC/MS analytical procedure. The atrazine concentrations were higher substantially and more variable at the La Moine River at Colmar and the Sangamon River at Monticello. About 63 percent of the samples collected at the La Moine River at Colmar in May and June exceeded the atrazine MCL (fig. 6), and 75 percent of these samples exceeded the AQCR guideline. The maximum concentration observed at Colmar was $110 \mu \mathrm{g} / \mathrm{L}$, which was detected in May 1997 during a high-flow condition (4-percent exceedance probability) and under high antecedent soil-moisture conditions. This value was the highest atrazine concentration observed during the 1996-98 data-collection period at all sample sites. About 61 percent of the samples collected at the Sangamon River at Monticello in May and June exceeded the atrazine MCL (fig. 6), and about 79 percent of these samples exceeded the AQCR guideline. The maximum concentration at Monticello was $32 \mu \mathrm{g} / \mathrm{L}$, which was detected in May 1997, when the streamflow was increasing rapidly in response to local precipitation. This sample was the first of 10 samples collected at Monticello in approximately equal increments over a 4-day period to observe the shortterm changes in pesticide concentrations after an earlyspring storm. The changes in pesticide concentration with stream discharge for atrazine, the atrazine transformation product DEA, and the related triazine herbicide cyanazine for a 1-month period are shown in figure 7. The Monticello storm samples in which the atrazine concentration exceeded the MCL are associated closely with the rising and peak portions of the streamflow hydrograph.
At all the intensive sample sites, the atrazine concentrations measured in May and June that exceeded the drinking-water MCL always were observed during above-average flow conditions (defined as stream discharge greater than the 50-percent exceedance probability). However, nearly half of all pesticide samples collected during extremely high-flow conditions (defined as stream discharge greater than the 10-percent exceedance probability) were acquired during the months other than May and June. Most of these pesticide samples were collected in the months of February, March, April, July, and August, immediately before and after May and June where the high concentrations were observed. This suggests that elevated atrazine concentrations above the drinkingwater MCL are associated more closely with time of application (late spring-early summer), rather than streamflow condition. However, the effect of flow on pesticide concentration for samples collected at extremely high-flow conditions in May to June remains notable, as the samples collected at extremely highflow conditions in May to June had an average atrazine concentration of about $12 \mu \mathrm{g} / \mathrm{L}$, compared to an average atrazine concentration of $5.5 \mu \mathrm{g} / \mathrm{L}$ for all other May to June samples.

\section{Bentazon}

Bentazon is a general-use herbicide and is not assigned to a chemical class. Bentazon is applied postemergence for the selective control of broadleaf weeds and sedges. Bentazon works as a contact herbicide, which means that it causes injury only to the parts of the plant to which it is applied (Extoxnet, 2000). The average bentazon use during 1996-98 was about 170 ton/yr, and its year-to-year usage during this period varied considerably (table 5 ).

Bentazon was detected in 59 percent of samples at an average concentration of $0.20 \mu \mathrm{g} / \mathrm{L}$ and a median concentration of $0.10 \mu \mathrm{g} / \mathrm{L}$ (fig. 5). Bentazon was detected at all the sample stations except the Fox River at Dayton; however, it was only intermittently detected at the Illinois River sites. It most consistently was detected at the La Moine River at Colmar and the Sangamon River at Monticello. The maximum concentration was $1.6 \mu \mathrm{g} / \mathrm{L}$ (HAL guideline is 200 $\mu \mathrm{g} / \mathrm{L}$ ), which was observed during high-flow condition (1-percent exceedance probability) at the Sangamon River at Monticello in June 1998. 


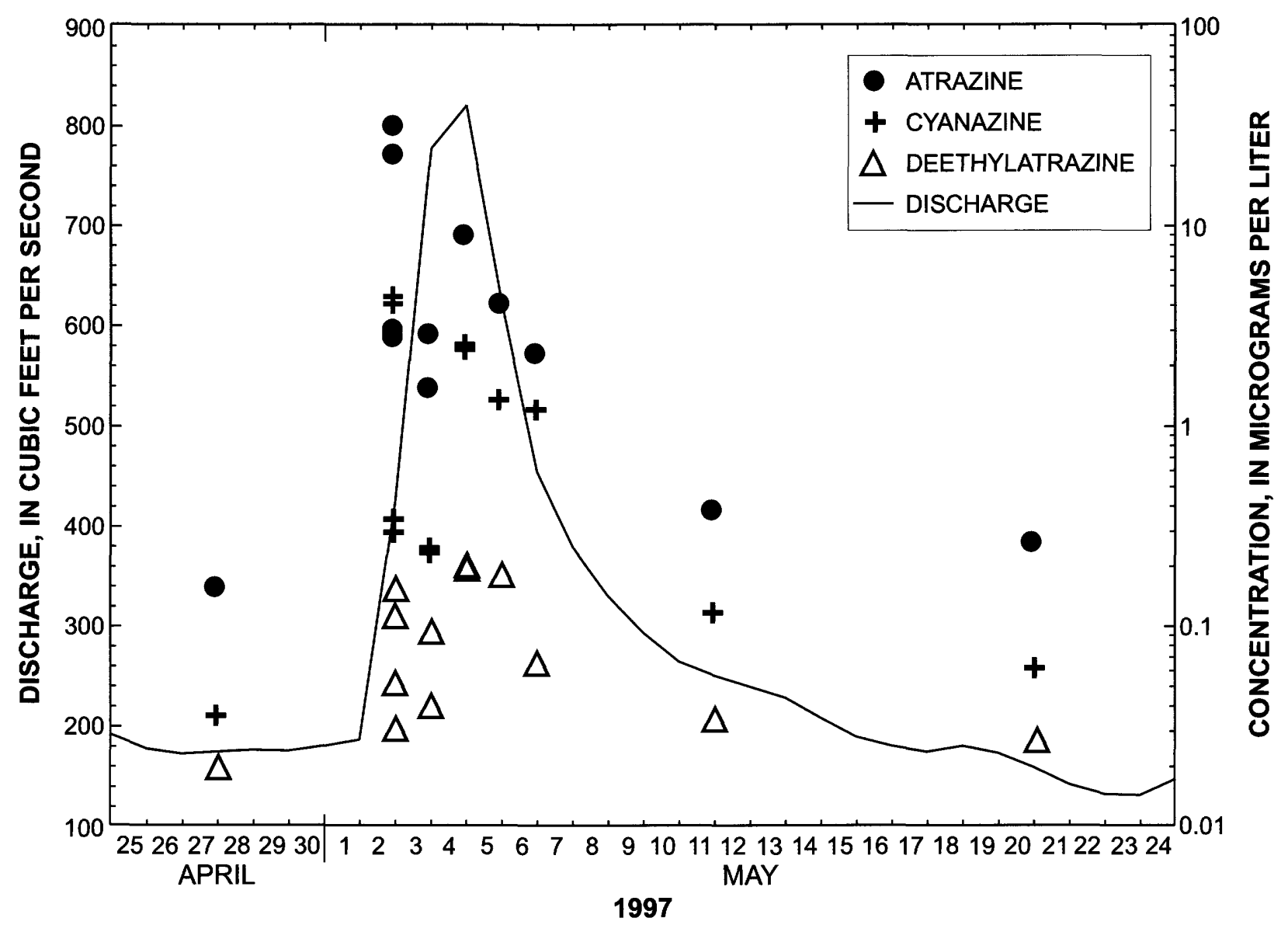

Figure 7. Concentrations of selected pesticides in the Sangamon River at Monticello, lower Illinois River Basin, during an early spring storm, post application, 1997.

\section{Bromoxynil}

Bromoxynil is a restricted-use herbicide and belongs to the nitrile class. Bromoxynil is used for post-emergent control of annual broadleaf weeds and is not registered for homeowner use (Extoxnet, 2000). The average use during 1996-98 was about 35 tons per year (table 5). Bromoxynil usage was lower by about 20 percent during 1997 compared to 1996 and 1998.

Bromoxynil was detected in 2 percent of samples at an average concentration of $0.06 \mu \mathrm{g} / \mathrm{L}$ and a median concentration of $0.06 \mu \mathrm{g} / \mathrm{L}$ (fig. 5). The maximum concentration was $0.14 \mu \mathrm{g} / \mathrm{L}$ (AQCR guideline is $5 \mu \mathrm{g} / \mathrm{L}$ ), which was observed at the Sangamon River at Monticello during an 11-percent exceedance probability flow condition in June 1997. Bromoxynil also was detected in the Illinois River at Ottawa and the La Moine River at Colmar. Two of the detections were below the MDL of $0.04 \mu \mathrm{g} / \mathrm{L}$ and their concentrations were estimated.

\section{Butylate}

Butylate is a general-use herbicide and belongs to the thiocarbamate class. Butylate application is limited to cornfields for the control of grassy weeds, such as nutgrass and millet grass, as well as some broadleaf weeds. It is applied to soil immediately before corn is planted, often in combination with atrazine and/or cyanazine (Extoxnet, 2000).

Butylate was detected in 10 percent of samples at an average concentration of $0.02 \mu \mathrm{g} / \mathrm{L}$ and a median concentration of $0.015 \mu \mathrm{g} / \mathrm{L}$ (fig. 5). Nearly all detections of butylate were in May to June at the La Moine River at Colmar and the Sangamon River at Monticello, although the compound also was detected at all the other sample stations. The maximum concentration was $0.09 \mu \mathrm{g} / \mathrm{L}$ (HAL guideline is $350 \mu \mathrm{g} / \mathrm{L}$ ), which was observed at the Sangamon River at Monticello during a high-flow condition (22-percent exceedance probability) in May 1997. 


\section{Carbaryl}

Carbaryl is a general-use insecticide and belongs to the carbamate class. It is a broad-spectrum insecticide that controls over 100 species of insects on fruit, forests, lawns, ornamentals, shade trees, and other crops, as well as on poultry, livestock, and pets.

Carbaryl also is used as a molluscicide and an acaricide (Extoxnet, 2000).

Carbaryl was detected in 8 percent of samples at an average concentration of $0.03 \mu \mathrm{g} / \mathrm{L}$ and a median concentration of $0.015 \mu \mathrm{g} / \mathrm{L}$ (fig. 5). It was detected at least once at every sample site except the Panther Creek near El Paso. The maximum concentration was $0.12 \mu \mathrm{g} / \mathrm{L}$ (AQCR guideline is $0.2 \mu \mathrm{g} / \mathrm{L}$ ), which was observed at the Sangamon River at Monticello during a high-flow condition (37-percent exceedance probability) in August 1998.

\section{Carbofuran}

Carbofuran is a restricted-use insecticide and belongs to the carbamate class. It is a broad-spectrum insecticide that kills insects, mites, and nematodes on contact or after ingestion. It is used against soil and foliar pests of field, fruit, vegetable, and forest crops (Extoxnet, 2000).

Carbofuran was detected in 15 percent of samples at an average concentration of $0.13 \mu \mathrm{g} / \mathrm{L}$ and a median concentration of $0.023 \mu \mathrm{g} / \mathrm{L}$ (fig. 5), and was detected at all the intensive sample sites. Nearly all concentrations of carbofuran were estimated because the MDL for this compound is $0.28 \mu \mathrm{g} / \mathrm{L}$. These estimated detections generally were found in June to August samples at the La Moine River at Colmar and the Sangamon River at Monticello, although the compound also was detected once $(0.04 \mu \mathrm{g} / \mathrm{L})$ at the Illinois River at Valley City in June 1998. The maximum concentration was $1.0 \mu \mathrm{g} / \mathrm{L}$ (AQCR guideline is $1.8 \mu \mathrm{g} / \mathrm{L}$ ), which was observed at the $\mathrm{La}$ Moine River at Colmar during a high-flow condition (4-percent exceedance probability) in May 1997.

\section{Chlorpyrifos}

Chlorpyrifos is a general-use insecticide and belongs to the organophosphate class. It is a broadspectrum insecticide used to control cutworms, corn rootworms, cockroaches, grubs, flea beetles, flies, termites, fire ants, and lice. It also is used on grain, field, fruit, vegetable crops, lawns, ornamental plants, sheep, turkeys, horse-site treatment, dog kennels, domestic dwellings, farm buildings, storage bins, and commercial establishments. While once used primarily to kill mosquitoes, it is no longer registered for this use (Extoxnet, 2000). The average use during the 1996-98 period was about 215 tons per year. However, chlorpyrifos use varied appreciably, as about twice as much chlorpyrifos was applied in 1997 than in either of 1996 or 1998 (table 5).

Chlorpyrifos was detected in 32 percent of samples at an average concentration of $0.04 \mu \mathrm{g} / \mathrm{L}$ and a median concentration of $0.02 \mu \mathrm{g} / \mathrm{L}$ (fig. 5), and was detected at all eight sample sites. There was no positive correlation between chlorpyrifos use and the observed mean concentrations. On the contrary, the 1997 mean concentration was $0.03 \mu \mathrm{g} / \mathrm{L}$ while the 1998 mean concentration - when the use was less than half that of 1997-was $0.06 \mu \mathrm{g} / \mathrm{L}$. However, the estimates of chlorpyrifos use reported in table 5 account only for agricultural applications, not urban applications, which may explain the lack of positive correlation. The maximum concentration of $0.30 \mu \mathrm{g} / \mathrm{L}$ was observed on three occasions in May 1998, all during high flow: twice at the La Moine River at Colmar during flow conditions of 3 and 11 percent exceedance probabilities and once at the Sangamon River at Monticello during a 1-percent exceedance probability flow condition. The AQCR guideline for chlorpyrifos is $0.04 \mu \mathrm{g} / \mathrm{L}$ and was exceeded in about 25 percent of the samples.

\section{Cyanazine}

Cyanazine is a restricted-use herbicide and belongs to the triazine class. Cyanazine is used as a pre- and post-emergent herbicide to control annual grasses and broadleaf weeds (Extoxnet, 2000). The average use for cyanazine during 1996-98 was about 805 tons per year. However, about 1,130 tons were used in 1996, and use declined to an average of about 643 tons per year in 1997 and 1998. Cyanazine was prohibited on January 1, 2003.

Cyanazine was detected in 97 percent of samples at an average concentration of $0.66 \mu \mathrm{g} / \mathrm{L}$ and a median concentration of $0.08 \mu \mathrm{g} / \mathrm{L}$ (fig. 5). Cyanazine concentrations sometimes exceeded the HAL drinkingwater guideline of $1 \mu \mathrm{g} / \mathrm{L}$ at all the intensive sample sites (the Illinois River at Ottawa, the Illinois River at Valley City, the La Moine River at Colmar, and the Sangamon River at Monticello). Cyanazine sometimes exceeded the AQCR of $2 \mu \mathrm{g} / \mathrm{L}$ in various samples. 
Almost without exception, all samples that exceeded the cyanazine drinking-water standard were collected in either May or June. About 56 percent of the samples from the Illinois River at Ottawa collected in May and June exceeded the HAL for cyanazine (fig. 8), and about 11 percent of these samples exceeded the AQCR guideline. The maximum cyanazine concentration at the Illinois River at Ottawa was $3 \mu \mathrm{g} / \mathrm{L}$, observed in May 1997 during a high-flow (21-percent exceedance probability) condition. About 83 percent of the waterquality samples collected from the Illinois River at Valley City in May and June exceeded the cyanazine HAL guideline (fig. 8), and 25 percent of these samples exceeded the AQCR guideline. Most of these elevated cyanazine concentrations measured at Valley City were between 1 and $2 \mu \mathrm{g} / \mathrm{L}$, although the maximum concentration was $3.9 \mu \mathrm{g} / \mathrm{L}$, observed in May 1996 during a high-flow condition (5-percent exceedance probability). The cyanazine concentrations were higher at the La Moine River at Colmar and the Sangamon River at Monticello. About 63 percent of the samples collected at the La Moine River at Colmar in May and June exceeded the cyanazine HAL (fig. 8), and 42 percent of these samples exceeded the AQCR guideline. The maximum cyanazine concentration at Colmar was $16 \mu \mathrm{g} / \mathrm{L}$, which was detected in May 1997 during a high-flow condition (4-percent exceedance probability). This value was the highest cyanazine concentration observed during the 1996-98 datacollection period at all sample sites. About 29 percent of the samples collected at the Sangamon River at Monticello in May and June exceeded the cyanazine HAL (fig. 8), and about 18 percent of these samples exceeded the AQCR guideline. The maximum concentration at Monticello was $5.8 \mu \mathrm{g} / \mathrm{L}$, which was detected in late May 1997 during a high-flow condition (3-percent exceedance probability). Cyanazine concentrations also were highly elevated in samples acquired immediately after heavy local precipitation in early May 1997, as shown in the Sangamon River at Monticello storm samples (fig. 7). Cyanazine concentrations exceeded the HAL during the rising and peak portions of the streamflow hydrograph. Elevated cyanazine concentrations (from 1.0 to $1.2 \mu \mathrm{g} / \mathrm{L}$ ) also were detected at the Panther Creek near El Paso in October and December 1996, during low-flow conditions (less than the 50-percent exceedance probability).

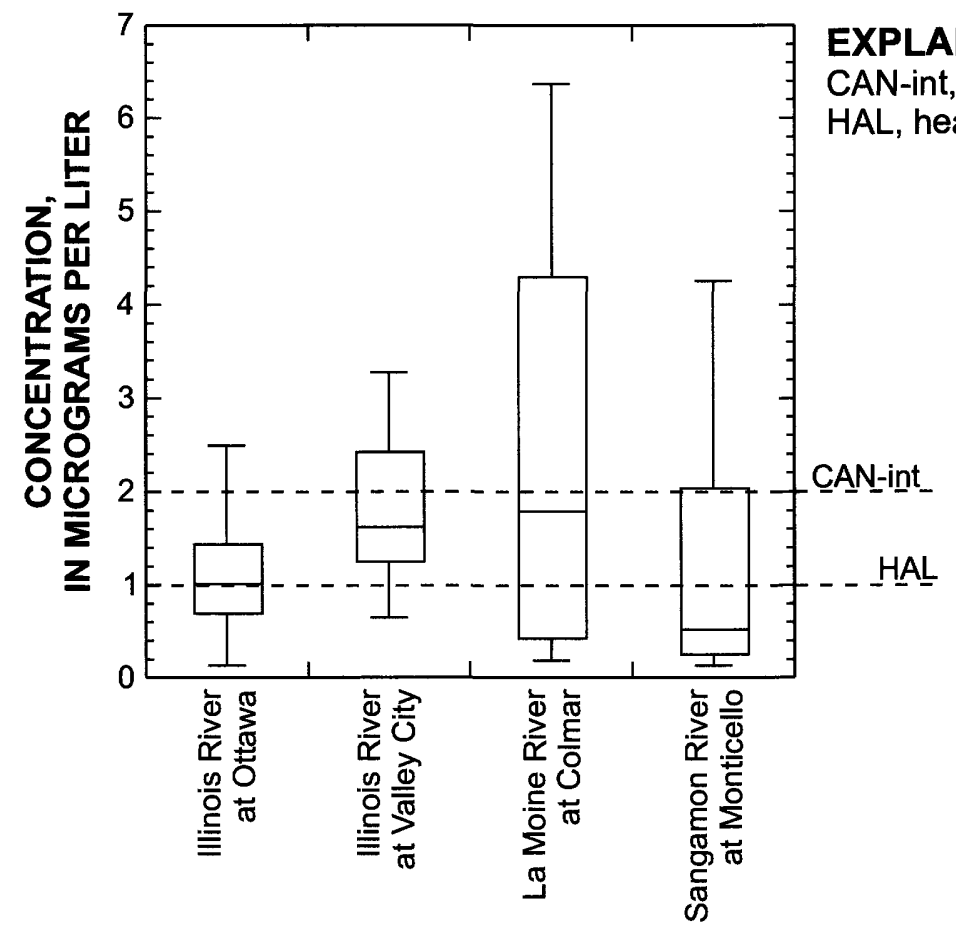

Figure 8. Cyanazine concentration at the intensive sample sites in the lower Illinois River Basin, May-June 1997-98. (See figure 4 for explanation of boxplots.) 
Cyanazine concentrations generally reach elevated levels during high-flow conditions in the months of May and June. Nearly half of all pesticide samples collected during flow conditions greater than the 10-percent exceedance probability were acquired during the months other than May and June. Most of these pesticide samples were collected in the months of February, March, April, July, and August, immediately before and after May and June, where the highest concentrations were observed. This result suggests that elevated cyanazine concentrations (like the related triazine-herbicide atrazine) are associated more closely with seasonality, rather than streamflow condition.

\section{DCPA}

DCPA is a general-use herbicide and belongs to the phthalate class. It is used pre-emergent on annual grasses and annual broadleaf weed species in a wide range of vegetable crops. About 20 percent of DCPA use is for homes and gardens (Extoxnet, 2000).

DCPA was detected in 15 percent of samples at an average concentration of $0.005 \mu \mathrm{g} / \mathrm{L}$ and a median concentration of less than $0.002 \mu \mathrm{g} / \mathrm{L}$ (fig. 5), which is below the MDL of $0.002 \mu \mathrm{g} / \mathrm{L}$. Over half of the reported DCPA detections were detected at concentrations below the MDL and were estimated by laboratory analytical methods at the NWQL. DCPA was detected at all sample sites except the Fox River at Dayton and Panther Creek near El Paso. The maximum concentration was $0.06 \mu \mathrm{g} / \mathrm{L}$, which was observed at the Illinois River at Ottawa during a 65-percent exceedance probability flow condition in May 1997.

\section{Diazinon}

Diazinon is a restricted-use insecticide and belongs to the organophosphate class. Diazinon is used to control cockroaches, silverfish, ants, and fleas in residential buildings. It is used on home gardens and farms to control a wide variety of sucking and leafeating insects. It is used on corn, fruit trees, potatoes, and on horticultural plants. In 1988, the USEPA banned diazinon use on golf courses and sod farms because of its effect on birds that often congregated in those areas (Extoxnet, 2000).
Diazinon was detected in 37 percent of samples at an average concentration of $0.03 \mu \mathrm{g} / \mathrm{L}$ and a median concentration of $0.02 \mu \mathrm{g} / \mathrm{L}$ (fig. 5). Nearly all detections of diazinon were in the Illinois River sites of Marseilles, Ottawa, and Valley City, and the Fox River at Dayton. The maximum concentration was $0.22 \mu \mathrm{g} / \mathrm{L}$, which exceeded the AQCR guideline of $0.08 \mu \mathrm{g} / \mathrm{L}$ (HAL guideline is $0.6 \mu \mathrm{g} / \mathrm{L}$ ). This maximum concentration was observed at the Illinois River at Ottawa during a high-flow condition (10-percent exceedance probability) in August 1998, and was the only time diazinon exceeded any of the water-quality standards or guidelines described in this report.

\section{Dicamba}

Dicamba is a general-use herbicide and belongs to the benzoic-acid class. It can be applied to the leaves or to the soil, and controls annual and perennial broadleaf weeds in grain crops and grasslands. It will kill broadleaf weeds before and after they sprout, and is used to control brush and bracken in pastures (Extoxnet, 2000). The use of dicamba in the study area remained fairly steady during 1996-98, and averaged about 133 tons per year.

Dicamba was detected in 9 percent of samples at an average concentration of $0.33 \mu \mathrm{g} / \mathrm{L}$ and a median concentration of $0.28 \mu \mathrm{g} / \mathrm{L}$ (fig. 5). Dicamba was detected at all the intensive sample sites plus the Indian Creek near Wyoming. The maximum concentration was $0.79 \mu \mathrm{g} / \mathrm{L}$, which substantially is below any waterquality standard or guideline described in this report. The maximum concentration was observed at the $\mathrm{La}$ Moine River at Colmar during a high-flow condition (2-percent exceedance probability) in June 1997.

\section{Dieldrin}

Dieldrin is an organochlorine-class insecticide that was once used on corn. The USEPA restricted its use starting in 1974 to termite control only, and then banned all uses in 1987 because of its effect on the central nervous system. Its half-life in certain soil conditions has been documented to be 868 days, which is much longer than most other pesticides presently in use (Extoxnet, 2000). Dieldrin is closely related to the insecticide aldrin and sometimes occurs in the environment as a transformation product of aldrin. 
Despite its lack of use in the study area, dieldrin was detected in 12 percent of samples at an average concentration of $0.005 \mu \mathrm{g} / \mathrm{L}$ and a median concentration of $0.004 \mu \mathrm{g} / \mathrm{L}$ (fig. 5). Most dieldrin detections were in May to June samples from the $\mathrm{La}$ Moine River at Colmar and the Sangamon River at Monticello. Dieldrin also was detected once $(0.004$ $\mu \mathrm{g} / \mathrm{L})$ at the Illinois River at Ottawa during a high-flow condition (5-percent exceedance probability) in June 1997, twice at the Illinois River at Valley City in March and June 1997 during high-flow conditions (5- and 20-percent exceedance probability, respectively), and twice at the Panther Creek near El Paso in November 1996 and January 1997 during lower-flow conditions. The maximum concentration was $0.018 \mu \mathrm{g} / \mathrm{L}$ (RSD drinking-water quality guideline is $0.02 \mu \mathrm{g} / \mathrm{L}$ ), which was observed at the La Moine River at Colmar during a high-flow condition (11-percent exceedance probability) in July 1998.

\section{Diuron}

Diuron is a general-use herbicide and belongs to the substituted urea class. Diuron is used to control a wide variety of annual and perennial broadleaf and grassy weeds, as well as mosses. It is used on non-crop areas and many agricultural crops such as fruit, alfalfa, and wheat (Extoxnet, 2000).

Diuron was detected in 32 percent of samples at an average concentration of $0.08 \mu \mathrm{g} / \mathrm{L}$ and a median concentration of $0.06 \mu \mathrm{g} / \mathrm{L}$ (fig. 5). About half the reported diuron detections were estimated, as they were at concentrations below the MDL of $0.05 \mu \mathrm{g} / \mathrm{L}$. Diuron was detected at all the intensive sample sites, most frequently from May to August. The compound also was detected once in the Panther Creek near El Paso. The maximum concentration was $0.32 \mu \mathrm{g} / \mathrm{L}$ (HAL guideline is $10 \mu \mathrm{g} / \mathrm{L}$ ), which was observed at the Sangamon River at Monticello during a 37-percent exceedance probability flow condition in August 1998.

\section{EPTC}

EPTC is a general-use herbicide and belongs to the thiocarbamate class. EPTC is a selective herbicide used to control annual grassy weeds, perennial weeds, and some broadleaf weeds in corn, beans, forage legumes, and potatoes. It usually is applied pre-emergent and incorporated into the soil immediately after application either mechanically or by overhead irrigation (Extoxnet, 2000).

EPTC was detected in 19 percent of samples at an average concentration of $0.008 \mu \mathrm{g} / \mathrm{L}$ and a median concentration of $0.006 \mu \mathrm{g} / \mathrm{L}$ (fig. 5). EPTC was detected at all sample sites except for the Panther Creek near El Paso. The maximum concentration was $0.029 \mu \mathrm{g} / \mathrm{L}$, which was observed at the La Moine River at Colmar during a high-flow condition (4-percent exceedance probability) in May 1997.

\section{Fonofos}

Fonofos is a restricted-use insecticide and belongs to the organophosphate class. It is used primarily used on corn (Extoxnet, 2000). Fonofos was detected in 2 percent of samples at both an average and median concentration of $0.009 \mu \mathrm{g} / \mathrm{L}$ (fig. 5). Fonofos was detected at two intensive sample sites, the Illinois River at Valley City and the Sangamon River at Monticello, and the Fox River at Dayton. The maximum concentration was $0.014 \mu \mathrm{g} / \mathrm{L}$ (HAL drinking-water guideline is $10 \mu \mathrm{g} / \mathrm{L}$ ), which was observed at the Illinois River atValley City during a high-flow condition (3-percent exceedance probability) in June 1996.

\section{Malathion}

Malathion is a general-use insecticide and belongs to the organophosphate class. Malathion is a broad-spectrum insecticide used for the control of sucking and chewing insects on fruits and vegetables, and also is used to control mosquitoes, flies, household insects, animal parasites (ectoparasites), and head and body lice. Introduced in 1950, it is one of the earliest organophosphate insecticides developed. Malathion also may be found in formulations with many other pesticides (Extoxnet, 2000).

Malathion was detected in 3 percent of samples at an average concentration of $0.008 \mu \mathrm{g} / \mathrm{L}$ and a median concentration of $0.006 \mu \mathrm{g} / \mathrm{L}$ (fig. 5). Two of the malathion detections were at concentrations below the MDL and were estimated. Malathion was detected at all the intensive sample sites except the Sangamon River at Monticello. It also was detected once at both the Fox River at Dayton and the Indian Creek near 
Wyoming. The maximum concentration was $0.02 \mu \mathrm{g} / \mathrm{L}$ (AQCR guideline is $0.1 \mu \mathrm{g} / \mathrm{L}$ ), which was observed at the Illinois River at Valley City during a high-flow condition (5-percent exceedance probability) in June 1998.

\section{Metolachlor}

Metolachlor is, in most cases, a general-use herbicide and belongs to the chloroacetanilide class. Metolachlor usually is applied to crops pre-emergent and also is applied to public road right-of-ways and to woody ornamentals (Extoxnet, 2000). The use in the study area during 1996-98 was about 1,270 tons per year and varied little (table 5). Metolachlor had the second highest use of all pesticides in the study area.

Metolachlor was detected in 100 percent of samples at an average concentration of $0.84 \mu \mathrm{g} / \mathrm{L}$ and a median concentration of $0.17 \mu \mathrm{g} / \mathrm{L}$ (fig. 5). The maximum concentration was $20 \mu \mathrm{g} / \mathrm{L}$ (HAL guideline is $70 \mu \mathrm{g} / \mathrm{L}$ ), which was observed at the Sangamon River at Monticello during a high-flow condition (1-percent exceedance probability) in May 1998. The metolachlor AQCR guideline of $7.8 \mu \mathrm{g} / \mathrm{L}$ was exceeded in four samples, all collected during May and at high-flow conditions; three at Monticello (1- to 13-percent exceedance probabilities) and one atValley City (5-percent exceedance probability).

\section{Metribuzin}

Metribuzin is a general-use herbicide and belongs to the triazine class. It is a selective herbicide used for control of annual grasses and numerous broadleaf weeds in field and vegetable crops, and in turfgrass (Extoxnet, 2000). The average use in the study area during 1996-98 was about 27 tons per year, however, this use varied appreciably. Maximum use was in 1997, when about 38 tons were applied, which was about 80 percent more than the average use for 1996 and 1998 of 21 tons per year.

Metribuzin was detected in 37 percent of samples at an average concentration of $0.06 \mu \mathrm{g} / \mathrm{L}$ and a median concentration of $0.03 \mu \mathrm{g} / \mathrm{L}$ (fig. 5), and was detected at all eight sample sites. Most detections were in samples collected from May to August. The maximum concentration was $0.60 \mu \mathrm{g} / \mathrm{L}$ (AQCR guideline is $1 \mu \mathrm{g} / \mathrm{L}$ ), which was observed at the La Moine River at
Colmar during a high-flow condition (11-percent exceedance probability) in May 1998.

\section{Pendimethalin}

Pendimethalin is a general-use herbicide and belongs to the dinitroamino-benzene class. It is a selective herbicide used to control most annual grasses and certain broadleaf weeds in field corn, soybeans, and other crops (Extoxnet, 2000). It is used both preemergent and early post-emergent. The average use in the study during 1996-98 was about 555 tons per year. Pendimethalin use steadily declined during this period, from 755 tons in 1996, to 570 tons in 1997, and to 339 tons in 1998; a decrease of about 55 percent (table 5).

Pendimethalin was detected in 23 percent of samples at an average concentration of $0.05 \mu \mathrm{g} / \mathrm{L}$ and a median concentration of $0.04 \mu \mathrm{g} / \mathrm{L}$ (fig. 5), and was detected at all eight sample sites. Most detections were observed in May to June samples. The maximum concentration was $0.23 \mu \mathrm{g} / \mathrm{L}$, which was observed at the La Moine River at Colmar during a high-flow condition (11-percent exceedance probability) in May 1998.

\section{Prometon}

Prometon is a nonselective general-use herbicide and belongs to the triazine class. It is not used on cropland or in green houses. The use of prometon is primarily urban related: for annual grass and broadleaf weed control in non-cropland areas, public road rightof-ways, and industrial lands. It can be applied both pre- and post-emergent. Prometon can persist for long periods, as its half-life has been observed to be as long as 2,227 days in soil, depending upon soil type, application rate, and moisture conditions (Extoxnet, 2000). Prometon application data are not reported by the IASS.

Prometon was detected in 93 percent of samples at an average concentration of $0.02 \mu \mathrm{g} / \mathrm{L}$ and a median concentration of $0.015 \mu \mathrm{g} / \mathrm{L}$ (fig. 5). Most of the reported prometon concentrations were estimated because the compound usually was detected at concentrations below the MDL of $0.018 \mu \mathrm{g} / \mathrm{L}$. Prometon was the fourth most frequently detected pesticide in the study area, and was detected consistently in samples year round, regardless of 
month. The maximum concentration was $0.12 \mu \mathrm{g} / \mathrm{L}$ (HAL guideline is $100 \mu \mathrm{g} / \mathrm{L}$ ), which was observed at the Sangamon River at Monticello during a 55-percent exceedance probability flow condition in July 1998.

\section{Propachlor}

Propachlor is a selective herbicide and belongs to the chloroacetanilde class. It is applied to corn, soybeans, and other crops. It generally is applied pre-emergent, although is sometimes applied to corn in the early post-emergent growth stage (Extoxnet, 2000).

Propachlor was detected in 10 percent of the samples at an average concentration of $0.04 \mu \mathrm{g} / \mathrm{L}$ and a median concentration of $0.013 \mu \mathrm{g} / \mathrm{L}$ (fig. 5). About one-third of the propachlor concentrations were estimated as they occurred at concentrations below the MDL of $0.007 \mu \mathrm{g} / \mathrm{L}$. Nearly all detections were in May to June at the La Moine River at Colmar and the Sangamon River at Monticello, although the compound also was detected once $(0.056 \mu \mathrm{g} / \mathrm{L})$ at the Illinois River at Marseilles in May 1996. The maximum concentration was $0.51 \mu \mathrm{g} / \mathrm{L}$ (HAL guideline is $90 \mu \mathrm{g} / \mathrm{L}$ ), which was observed at the Sangamon River at Monticello during a high-flow condition (10-percent exceedance probability) in May 1997.

\section{Simazine}

Simazine is a general-use herbicide and belongs to the triazine class. It generally is used as a selective herbicide for the control of annual grasses and broadleaf weeds, although at higher concentrations simazine is used for nonselective weed control on industrial lands (Extoxnet, 2000). Average use in the study area during 1996-98 was about 43 tons per year. However, there was considerable variation in use during this period: 46 tons in 1996, 51 tons in 1997, and 33 tons in 1998.

Simazine was detected in 78 percent of samples at an average concentration of $0.04 \mu \mathrm{g} / \mathrm{L}$ and a median concentration of $0.015 \mu \mathrm{g} / \mathrm{L}$ (fig. 5). The MDL for simazine is $0.005 \mu \mathrm{g} / \mathrm{L}$, and about 10 percent of the reported concentrations were observed below this level and were estimated. Simazine was detected consistently at all eight sample sites. The maximum simazine concentration was $1.4 \mu \mathrm{g} / \mathrm{L}$ (drinking-water MCL standard is $4 \mu \mathrm{g} / \mathrm{L}$ ), which was observed at the
Sangamon River at Monticello during a 31-percent exceedance probability flow condition in May 1997.

\section{Tebuthiuron}

Tebuthiuron is a general-use herbicide and belongs to the substituted urea class. Tebuthiuron is a broad-spectrum herbicide primarily used to control weeds in non-cropland areas, public road right-ofways, and industrial sites (Extoxnet, 2000).

Tebuthiuron was detected in 35 percent of samples at both an average and median concentration of $0.01 \mu \mathrm{g} / \mathrm{L}$ (fig. 5). About one-third of reported tebuthiuron concentrations were below the MDL of $0.01 \mu \mathrm{g} / \mathrm{L}$ and were estimated. Most tebuthiuron detections were at the large river sites of the Illinois River at Marseilles, Ottawa, and Valley City, and the Fox River at Dayton. However, it also was detected at all other sample sites except the Indian Creek near El Paso. The maximum concentration was $0.05 \mu \mathrm{g} / \mathrm{L}$ (AQCR guideline is $1.6 \mu \mathrm{g} / \mathrm{L}$ ), which was observed at the Sangamon River at Monticello during a 66-percent exceedance probability flow condition in August 1998.

\section{Terbacil}

Terbacil is a general-use herbicide and belongs to the substituted uracil class. Terbacil is used for selective control of both annual grasses, broad-leaved weeds, and some perennial weeds in both non-corn and non-soybean crops. It usually is sprayed on soil surfaces just before, or during, the period of active weed growth (Extoxnet, 2000).

Terbacil was detected in 7 percent of samples at both an average and median concentration of 0.016 $\mu \mathrm{g} / \mathrm{L}$ (fig. 5). All detections of terbacil were at the Illinois River sites of Marseilles, Ottawa, and Valley City. The maximum concentration was $0.05 \mu \mathrm{g} / \mathrm{L}$ (HAL guideline is $90 \mu \mathrm{g} / \mathrm{L}$ ), which was observed at the Illinois River at Marseilles during a high-flow condition (26-percent exceedance probability) in August 1996.

\section{Terbufos}

Terbufos is classified as a restricted-use insecticide when it is present in a commercial product at a concentration of 15 percent or more. Terbufos 
belongs to the organophosphate class. It is used primarily on corn and grain sorghum, and usually is applied at the time of planting (Extoxnet, 2000). The average use in the study area during 1997-98 was about 118 tons per year, though this use varied appreciably. Maximum use was about 180 tons in 1997, whereas about 97 and about 76 tons were used in 1996 and 1998, respectively.

Terbufos was detected in 2 percent of samples at both an average and median concentration of 0.014 $\mu \mathrm{g} / \mathrm{L}$ (fig. 5). All detections of terbufos were at the Sangamon River at Monticello, although there was one estimated detection (below the MDL of $0.013 \mu \mathrm{g} / \mathrm{L}$ ) at the La Moine River at Colmar. The maximum concentration was $0.03 \mu \mathrm{g} / \mathrm{L}$ (HAL guideline is $0.9 \mu \mathrm{g} / \mathrm{L}$ ), which was observed at the Sangamon River at Monticello during a high-flow condition (9-percent exceedance probability) in May 1998.

\section{Triallate}

Triallate is a general-use herbicide and belongs to the thiocarbamate class. It generally is applied to control grass weeds in field crops, and is used selectively to control wild oats, black grass, and annual meadow grass in barley, wheat, and other crops.

Depending on the crop that is treated, triallate will be used both pre-emergent and post-emergent (Extoxnet, 2000).

Triallate was detected in 16 percent of samples at an average concentration of $0.02 \mu \mathrm{g} / \mathrm{L}$ and a median concentration of $.009 \mu \mathrm{g} / \mathrm{L}$ (fig. 5). Nearly all detections of triallate were in the Illinois River intensive sample sites of Ottawa and Valley City. Most of these detections were observed in 1996 and 1997; the detection rate during this time period was nearly 100 percent for Ottawa samples and about 60 percent for Valley City samples. However, concentrations gradually declined in 1998, and no detections above the MDL were observed after May 1998 at Ottawa or after February 1998 atValley City. The maximum concentration was $0.12 \mu \mathrm{g} / \mathrm{L}$ (AQCR guideline is $0.24 \mu \mathrm{g} / \mathrm{L}$ ), which was observed at the Illinois River at Ottawa during a 53-percent exceedance probability flow condition in July 1997.

\section{Trifluralin}

Trifluralin is a general-use herbicide and belongs to the dinitroaniline class. Trifluralin is a selective pre-emergent herbicide used to control many annual grasses and broadleaf weeds in a large variety of tree fruit, vegetable, and grain crops, including soybeans and alfalfa (Extoxnet, 2000). The average use in the study area during 1996-98 was about 154 tons per year but varied considerably, as the 1997 use of 233 tons was over twice the 1996 and 1998 average use of 114 tons per year (table 5).

Trifluralin was detected in 26 percent of samples at an average concentration of $0.005 \mu \mathrm{g} / \mathrm{L}$ and a median concentration of slightly greater than $0.004 \mu \mathrm{g} / \mathrm{L}$

(fig. 5). Trifluralin was detected at all four intensivesample sites, although most detections were at the nonIllinois River sites of the La Moine River at Colmar and the Sangamon River at Monticello. The compound also was detected at the Panther Creek near El Paso in June to July 1998. The maximum concentration was 0.016 $\mu \mathrm{g} / \mathrm{L}$ (HAL guideline is $5 \mu \mathrm{g} / \mathrm{L}$ and AQCR guideline is $0.2 \mu \mathrm{g} / \mathrm{L}$ ), which was observed twice at the Sangamon River at Monticello, first in June 1997 during a 24percent exceedance probability flow condition and second in May 1998 during a 9-percent exceedance probability flow condition.

\section{2,4-D}

2,4-D is a general-use herbicide and belongs to the chlorinated phenoxy class. 2,4-D usually is applied post-emergent (and pre-emergent on no-till farm land) and comes in many forms or derivatives. It is used as a systemic herbicide to control many types of broadleaf weeds in cropland, pasture, home, garden, and to control aquatic vegetation (Extoxnet, 2000). The average use in the study area during 1996-98 was about 209 tons per year. The use varied appreciably during this period; only 93 tons were used in 1997, while the average use for 1996 and 1998 was about 267 tons per year, nearly 3 times more.

2,4-D was detected in 31 percent of samples at an average concentration of $0.63 \mu \mathrm{g} / \mathrm{L}$ and a median concentration of $0.035 \mu \mathrm{g} / \mathrm{L}$ (fig. 5). About 25 percent of the reported 2,4-D concentrations were below the MDL of $0.11 \mu \mathrm{g} / \mathrm{L}$ and were estimated. 2,4-D was 
detected at all sample sites that included it as a target for analysis, which were the four intensive sample sites plus Indian Creek near Wyoming and Panther Creek near El Paso. (2,4-D was not a target for analysis at the Fox River at Dayton and the Illinois River at Marseilles.) The maximum concentration ( $7.3 \mu \mathrm{g} / \mathrm{L}$ that exceeds the AQCR guideline of $4 \mu \mathrm{g} / \mathrm{L}$ ) was observed at the La Moine River at Colmar during a high-flow condition (11-percent exceedance probability) in May 1998. This is the only time the 2,4-D aquatic guideline was exceeded, although three samples collected in early May 1997 at 6-hour intervals immediately after local precipitation had 2,4-D concentrations of $3.6,3.9$, and $3.4 \mu \mathrm{g} / \mathrm{L}$, respectively.

\section{Herbicide Transformation Product Concentrations}

Little is known about the effect of pesticide transformation products on human health and aquatic systems. However, research into the effect of pesticide transformation products has tended to focus on certain areas of concern. Many studies suggest that the toxicological effects of pesticide transformation products can vary greatly, and depend primarily on the species of organism considered (Day, 1991). Another areas of concern is the cumulative effect of combinations of pesticides and their transformation products, as most toxicity studies consider the effect of only one pesticide at a time. Yet another area of concern is the potential for bioaccumulation of transformation products, particularly in aquatic biota. Some governmental authorities throughout the country, in the absence of scientific evidence, have considered that pesticide transformation products have the same toxicity as the parent pesticide. For example, in Wisconsin, the State Department of Health and Social Services has proposed that the regulatory standard for atrazine be established as the sum concentration of both atrazine and the atrazine transformation products. The State of Illinois does not have regulatory standards for the transformation products of compounds described in this report.

Laboratory analyses at the OGRL included nine herbicide transformation products, all belonging to either the triazine or chloroacetanilide class. These nine compounds are transformation products of those herbicides that account for about 80 percent of the pesticides applied annually in the study area by weight, on average. All of the OGRL-analyzed transformation product concentration data were collected in 1998 at the four intensive-sample sites: the Illinois River at Ottawa, Sangamon River at Monticello, La Moine River at Colmar, and Illinois River at Valley City. These OGRL transformation product concentration data are shown in table 13. However, the transformation product deethylatrazine is part of NWQL schedule 2010, and thus, was measured along with the other schedule- 2010 pesticide samples for the entire 1996-98 data-collection period. Deethylatrazine concentrations measured as part of schedule-2010 water-quality samples previously were reported in the annual USGS Water-Resources Data reports for the State of Illinois (Wicker and others, 1997, 1998; LaTour and others, 1999).

\section{Chloroacetanilide-Class Transformation Products}

Laboratory analyses were performed for two chloroacetanilide-class transformation products, ethane sulfonic acid (ESA) and oxanilic acid (OXA), of the herbicides acetochlor, alachlor, and metolachlor (table 8). The pathways for the degradation of acetochlor, alachlor, and metolachlor into their component transformation products are shown in figure 9. The transformation products acetochlor ESA, alachlor ESA, and metolachlor ESA were detected in over 90 percent of the water-quality samples. Metolachlor OXA was detected in 74 percent of samples, whereas acetochlor OXA was detected in 59 percent of the samples. Alachlor OXA was detected in 3 percent of the samples.

Metolachlor ESA generally was the transformation product observed at the highest concentrations at the four intensive sample sites and was detected in 33 of 34 samples. The average concentration of metolachlor ESA was $2.22 \mu \mathrm{g} / \mathrm{L}$ and the median concentration was $1.6 \mu \mathrm{g} / \mathrm{L}$ (fig. 10). The maximum concentration $(6.1 \mu \mathrm{g} / \mathrm{L})$ was observed at the Sangamon River at Monticello in August 1998. Acetochlor ESA was detected in 32 samples at an average concentration of $1.1 \mu \mathrm{g} / \mathrm{L}$ and a median concentration of $0.84 \mu \mathrm{g} / \mathrm{L}$ (fig. 10). The maximum acetochlor ESA concentration was $2.6 \mu \mathrm{g} / \mathrm{L}$, observed at the Sangamon River at Monticello (station number $5572000)$ in July 1998. 
ริ

灾

:

$\stackrel{0}{5}$

ذั

s.

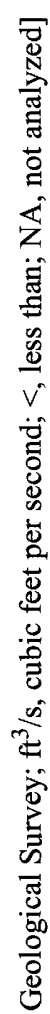

ஸे

பू

这

$\stackrel{.=}{=}$

(a)

ర

:

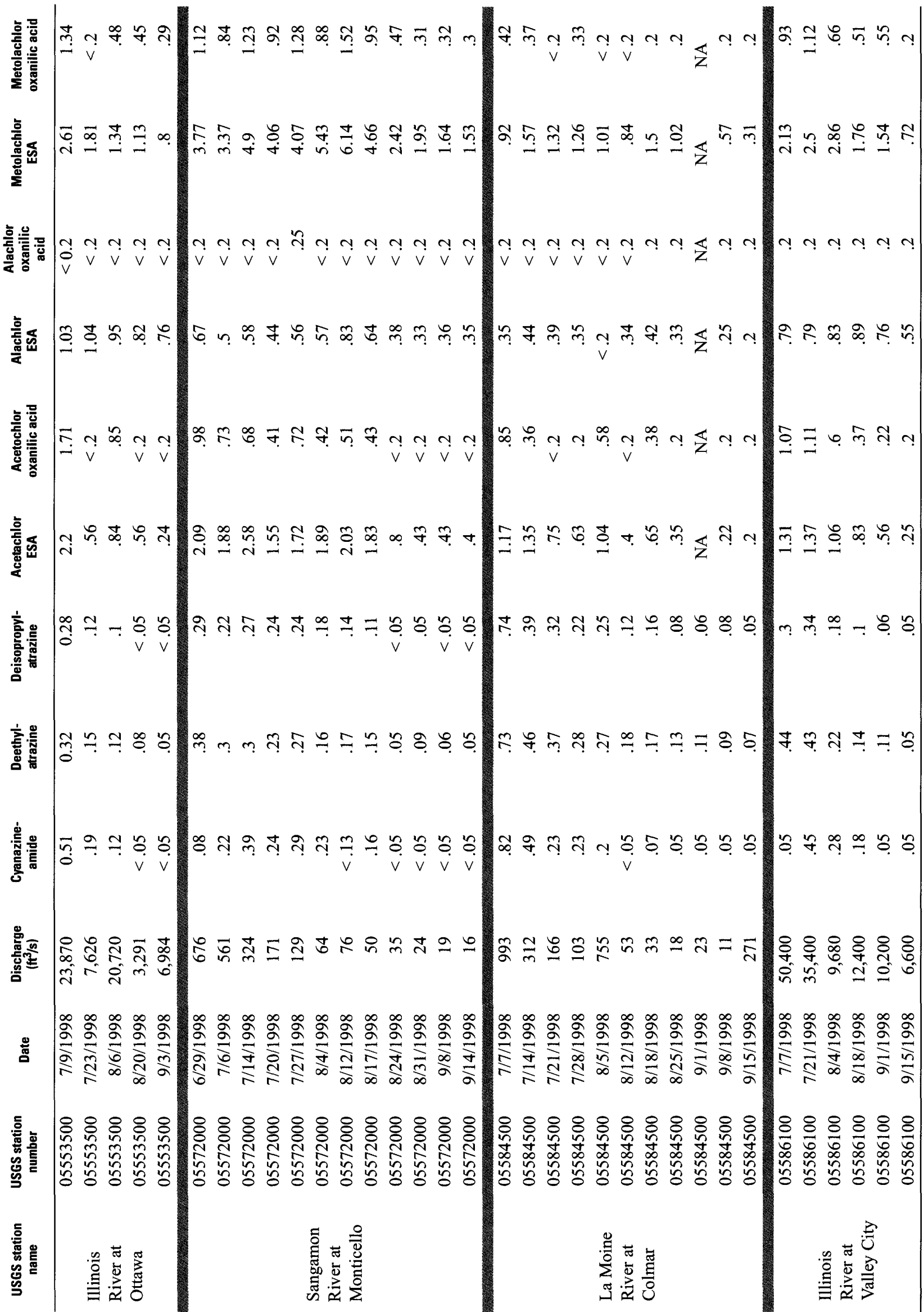



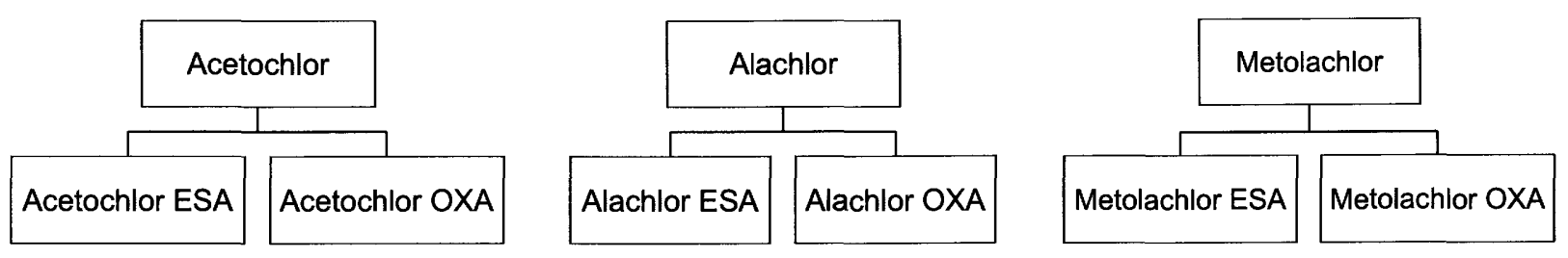

Figure 9. Pathways for degradation of acetochlor, alachlor, and metolachlor.

Alachlor ESA was detected in 31 samples with an average concentration of $0.58 \mu \mathrm{g} / \mathrm{L}$ and a median concentration of $0.56 \mu \mathrm{g} / \mathrm{L}$ (fig. 10). The maximum concentration $1.0 \mu \mathrm{g} / \mathrm{L}$ was observed at the Illinois River at Ottawa in July 1998. The concentrations of ESA transformation products generally were from 5 to 30 times higher than the concentration of their respective parent compounds and reached their maximum values from July to August.

The OXA transformation products of acetochlor, alachlor, and metolachlor were detected less frequently and generally at lower concentrations than the ESA transformation products. Metolachlor OXA was detected in 25 samples at an average concentration of 0.71 and median concentration of $0.55 \mu \mathrm{g} / \mathrm{L}$ (fig. 10). Acetochlor OXA was detected in 20 samples at an average concentration of $0.67 \mu \mathrm{g} / \mathrm{L}$ and a median concentration of $0.59 \mu \mathrm{g} / \mathrm{L}$ (fig 10). Alachlor OXA was detected in one sample at a concentration of $0.25 \mu \mathrm{g} / \mathrm{L}$. The OXA transformation product concentrations generally were from 3 to 10 times higher than their respective parent compounds. The maximum OXA concentrations were observed from July to August 1998 .

\section{Triazine-Class Transformation Products}

The triazine-class transformation products (table 8) include deethylatrazine (DEA), deisopropylatrazine (DIA), and cyanazine amide (CAM). The pathways for the degradation of atrazine, cyanazine, and simazine are shown in figure 11. DEA is a transformation product of the herbicide atrazine. DIA is a transformation product of the herbicides atrazine, cyanazine, and simazine. Although DIA is a transformation product of these three herbicides, studies show that DIA has atrazine as its major source (75 percent) and cyanazine as its secondary source ( 25 percent), and only trace amounts of DIA are contributed by simazine (Elisabeth A. Scribner, U.S. Geological Survey, written commun., 2000). CAM is a transformation product of cyanazine.

The atrazine transformation product DEA was detected in 100 percent of both the OGRL and the NWQL water-quality samples (34 and 258 detections, respectively). The average DEA concentration in these samples was $0.14 \mu \mathrm{g} / \mathrm{L}$ and the median was $0.08 \mu \mathrm{g} / \mathrm{L}$. The maximum concentration $(1.6 \mu \mathrm{g} / \mathrm{L})$ was observed at the La Moine River at Colmar during a high-flow condition (3-percent exceedance probability) in June 1998. DEA generally was observed at concentrations lower than the parent product atrazine. The transformation product DIA was detected in 28 of 34 OGRL samples and at higher concentrations than DEA. The average concentration of DIA was $0.20 \mu \mathrm{g} / \mathrm{L}$ and the median concentration was about $0.10 \mu \mathrm{g} / \mathrm{L}$ (fig. 12). A comparison of these DIA averages and medians to the transformation product DEA cannot be made directly because the OGRL samples all were collected during the 1998 growing season, whereas the DEA samples were collected continuously as part of schedule 2010 during the entire 1996-98 datacollection period. However, the DEA samples collected concurrently with DIA as part of the 1998 OGRL samples had an average concentration of 0.21 $\mu \mathrm{g} / \mathrm{L}$ and a median concentration of about $0.10 \mu \mathrm{g} / \mathrm{L}$, which are similar to the observed DIA concentrations (fig. 12). In general, the transformation products DEA and DIA were not observed at higher concentrations than their parent compounds (fig. 12). 


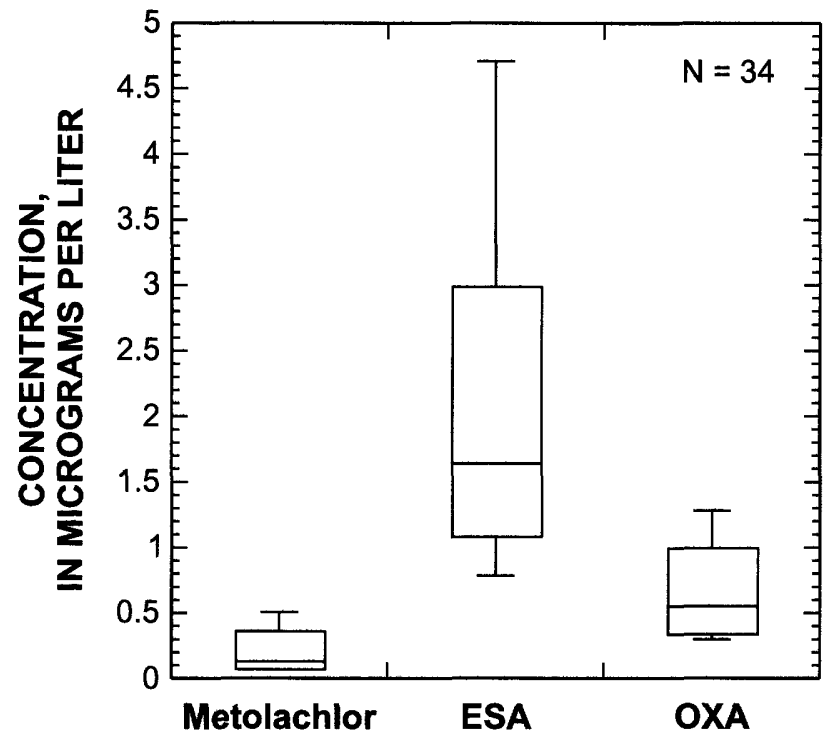

\section{EXPLANATION}

$\mathrm{N}$, number of samples

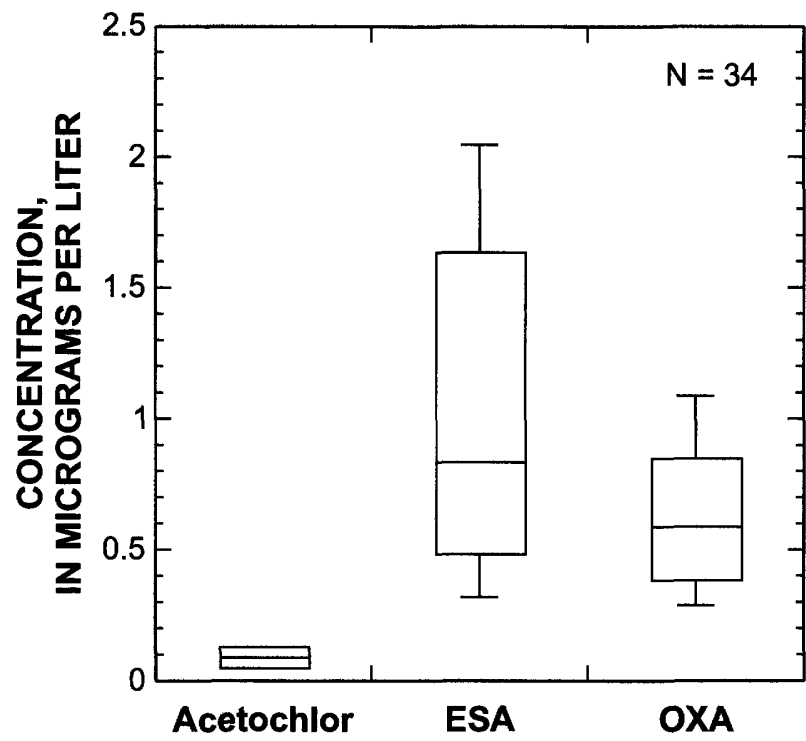

\section{EXPLANATION}

$\mathrm{N}$, number of samples

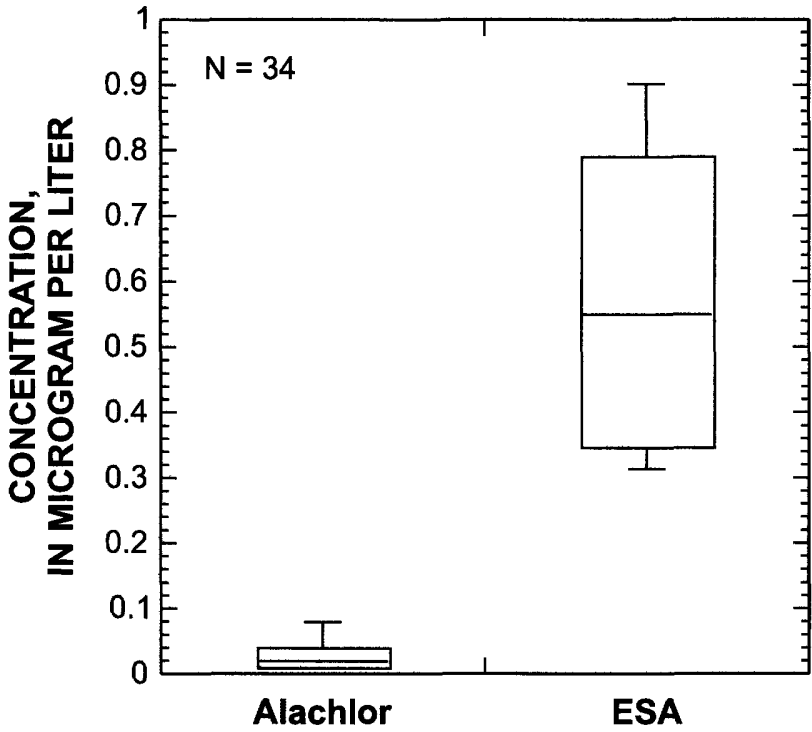

EXPLANATION

$\mathrm{N}$, number of samples

Figure 10. Concentrations of selected chloroacetanilide-class herbicide transformation products and their parent products at the intensive sample sites in the lower Illinois River Basin, July-September 1998. 
Selected triazine-class herbicides

and their transformation products
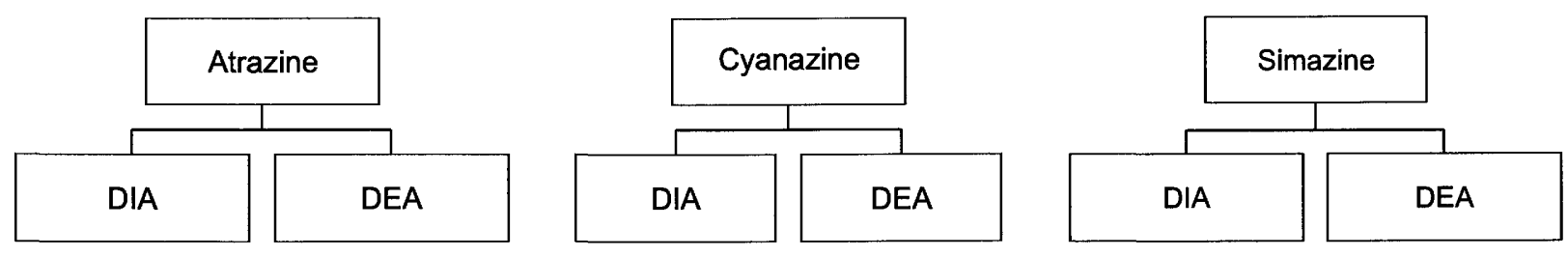

Figure 11. Pathways for degradation of atrazine, cynazine, and simazine.

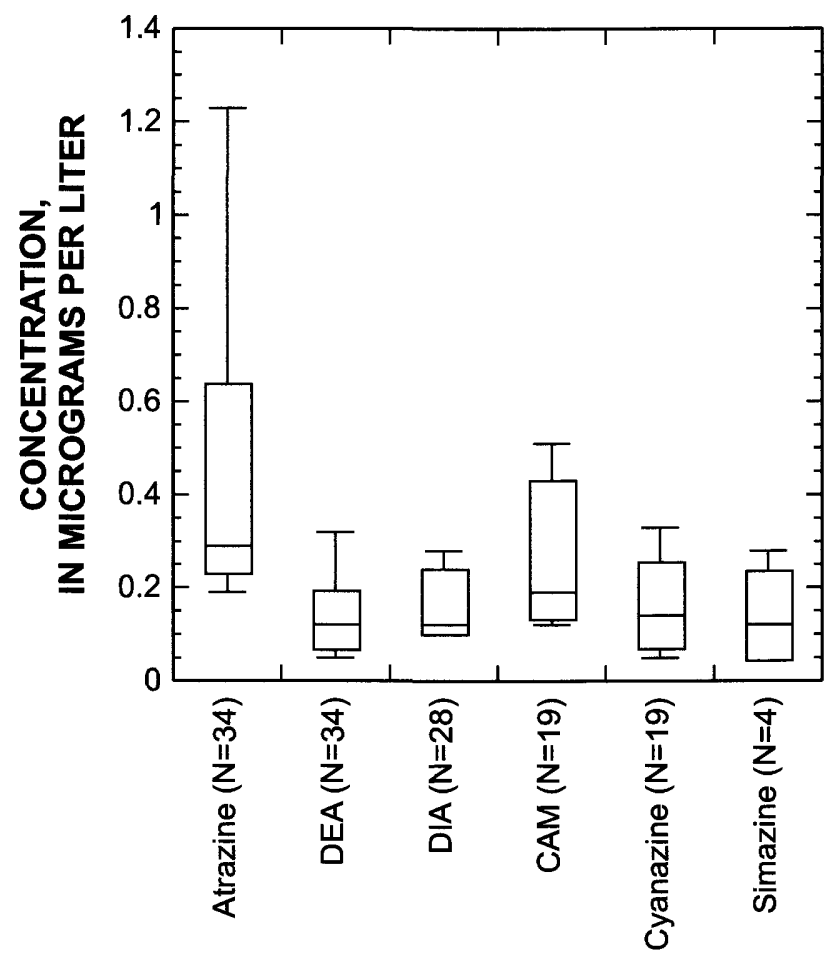

EXPLANATION

$\mathrm{N}$, number of samples

Figure 12. Concentrations of selected triazine-class herbicide transformation products and their parent products at the intensive sample sites in the lower Illinois River Basin, July-September 1998. (See figure 4 for explanation of boxplots.) 
The transformation product CAM was detected in 20 of 34 OGRL samples at an average concentration of 0.28 $\mu \mathrm{g} / \mathrm{L}$ and a median concentration of $0.18 \mu \mathrm{g} / \mathrm{L}$ (fig. 12). CAM was the only triazine transformation product to usually occur at concentrations higher than its parent compound (cyanazine). The maximum CAM concentration $(0.82 \mu \mathrm{g} / \mathrm{L})$ was observed at the $\mathrm{La}$ Moine River at Colmar in July 1998.

Thurman and Fallon (1996) demonstrated that the DEA-to-atrazine ratio (DAR) might be used to document the first major runoff event of herbicide from cornfields to surface water and to provide insight to the persistence of DEA in surface water. In their research, the DAR decreased from about 0.5 to less than 0.1 with the application of atrazine and the first occurrence of a major runoff event in the basin. The DAR then gradually increased to between 0.4 to 0.6 during the crop harvest season. The DAR for the Sangamon River at Monticello was computed for all NWQL-analyzed samples collected from October 1996 through September 1998 (fig. 13), which includes two annual cycles of agricultural activity (planting, herbicide application, and harvest). During the early spring months for each of the years 1997 and 1998, when crops are being planted, the DAR reached its maximum value in late March 1997 and in mid April 1998, respectively. In both years, the DAR then rapidly decreased within the span of 1-4 weeks and, by early May, to its annual minimum value of less than 0.02 . This quick decrease in the DAR indicates the spring

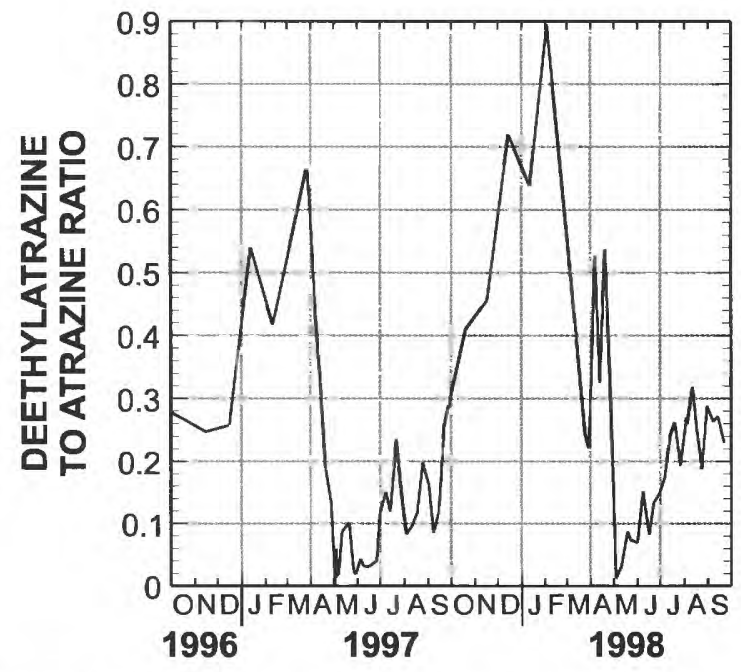

Figure 13. Deethylatrazine to atrazine ratio for the Sangamon River at Monticello in the lower Illinois River Basin, October 1996-September 1998. first-flush of atrazine, and is corroborated by the greatly increased atrazine concentrations observed at Monticello during May (figs. 6 and 7). The DAR then gradually increased during the course of the growing season, until it again reached the annual maximum. This result was notable particularly in 1997, when the DAR rapidly increased starting in September, when the harvest began, and continued to increase until February 1998 , when the DAR peaked at a value of about 0.9 . Thus, the transformation product DEA is a small portion of the total combined concentration of atrazine and DEA during the corn-growing season. However, because of the persistence of DEA, its relative concentration increases in the period from about harvest to the next planting season, when the parent compound generally is found at lower concentrations.

\section{Estimated Loads of Selected Herbicides}

Herbicide loads were estimated for atrazine, metolachlor, acetochlor, and cyanazine for the Illinois River at Ottawa and the Illinois River at Valley City. These loads were estimated based on computerized regression analysis done with a program that implements the adjusted maximum likelihood estimator (AMLE) described in Cohn (1988) and Cohn and others (1992). The AMLE is similar to the minimum variance unbiased estimator (MVUE) described in Cohn and others (1989) and Gilroy and others (1990) with one important exception; the AMLE is better suited for estimating loads with censored data, where some of the measured concentration values are below the MDL for the given constituent. The AMLE load program requires various input files consisting in part of sample date and time, chemical concentration, and mean daily discharge. The program output includes estimated daily loads, estimated loads at the upper and lower limits of the 95-percent confidence interval, and some regression diagnostic statistics.

Estimated daily loads for the period from January 1, 1996, through September 30, 1998, are plotted for the herbicides atrazine, metolachlor, acetochlor, and cyanazine (fig. 14). The estimated daily loads for these four herbicides were greatest between March and July of each year. The estimated peak loads for atrazine, acetochlor, and cyanazine in the Illinois River at Valley City generally were two to three times greater than in the Illinois River at Ottawa, whereas the peak loads for metolachlor generally were similar at these two sites. 


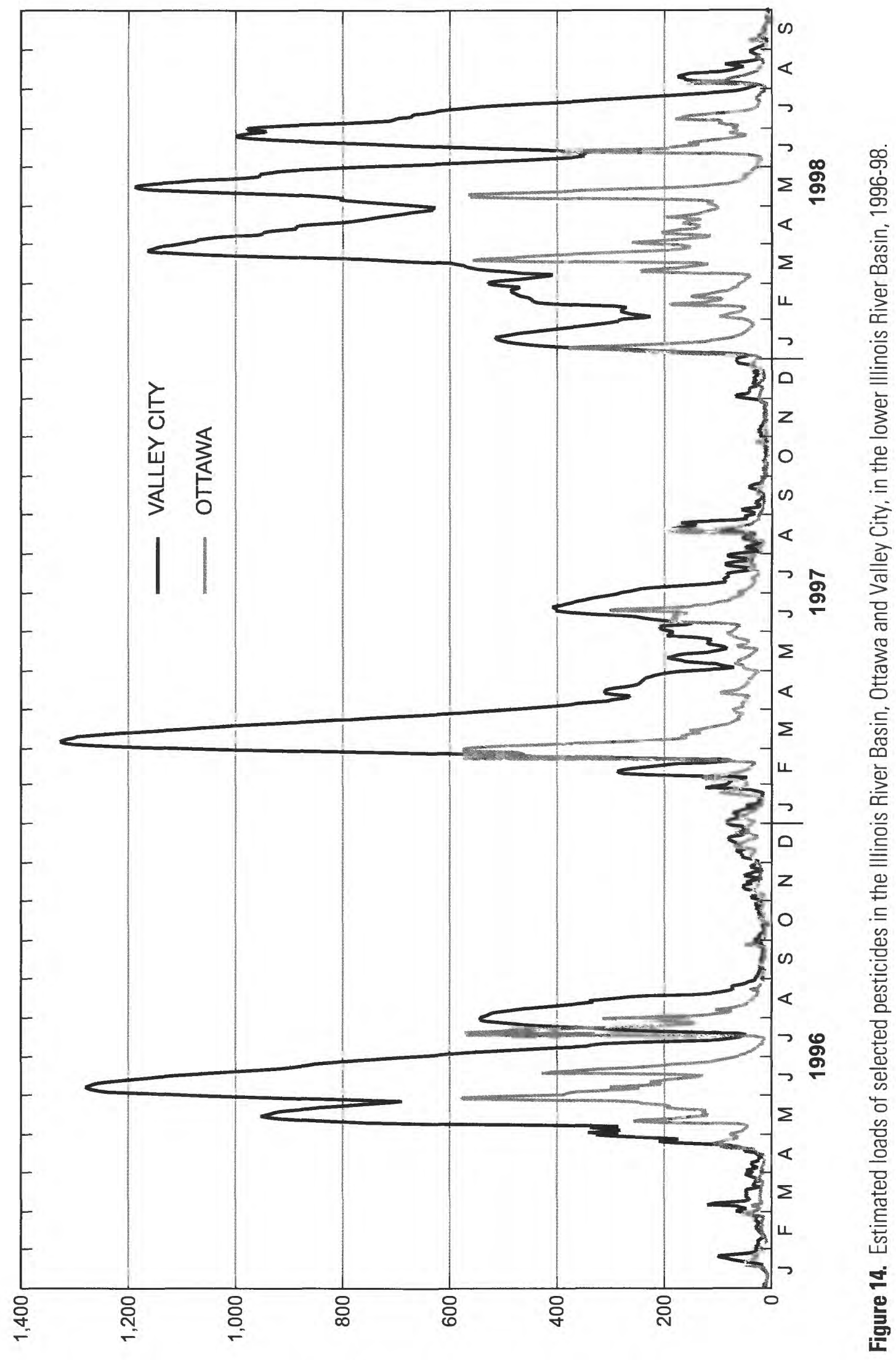

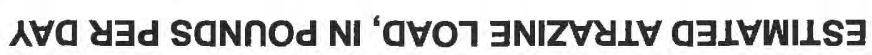




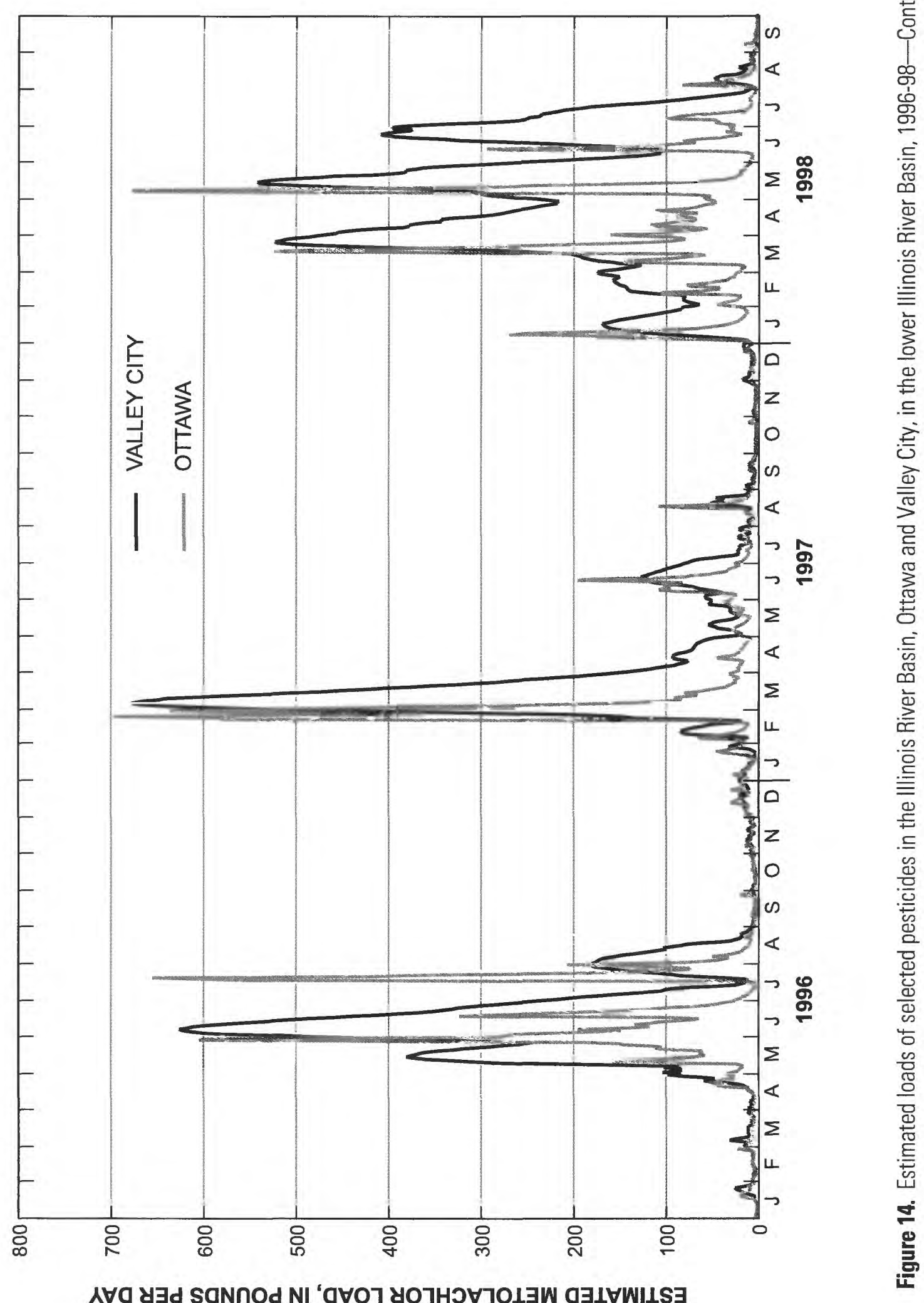




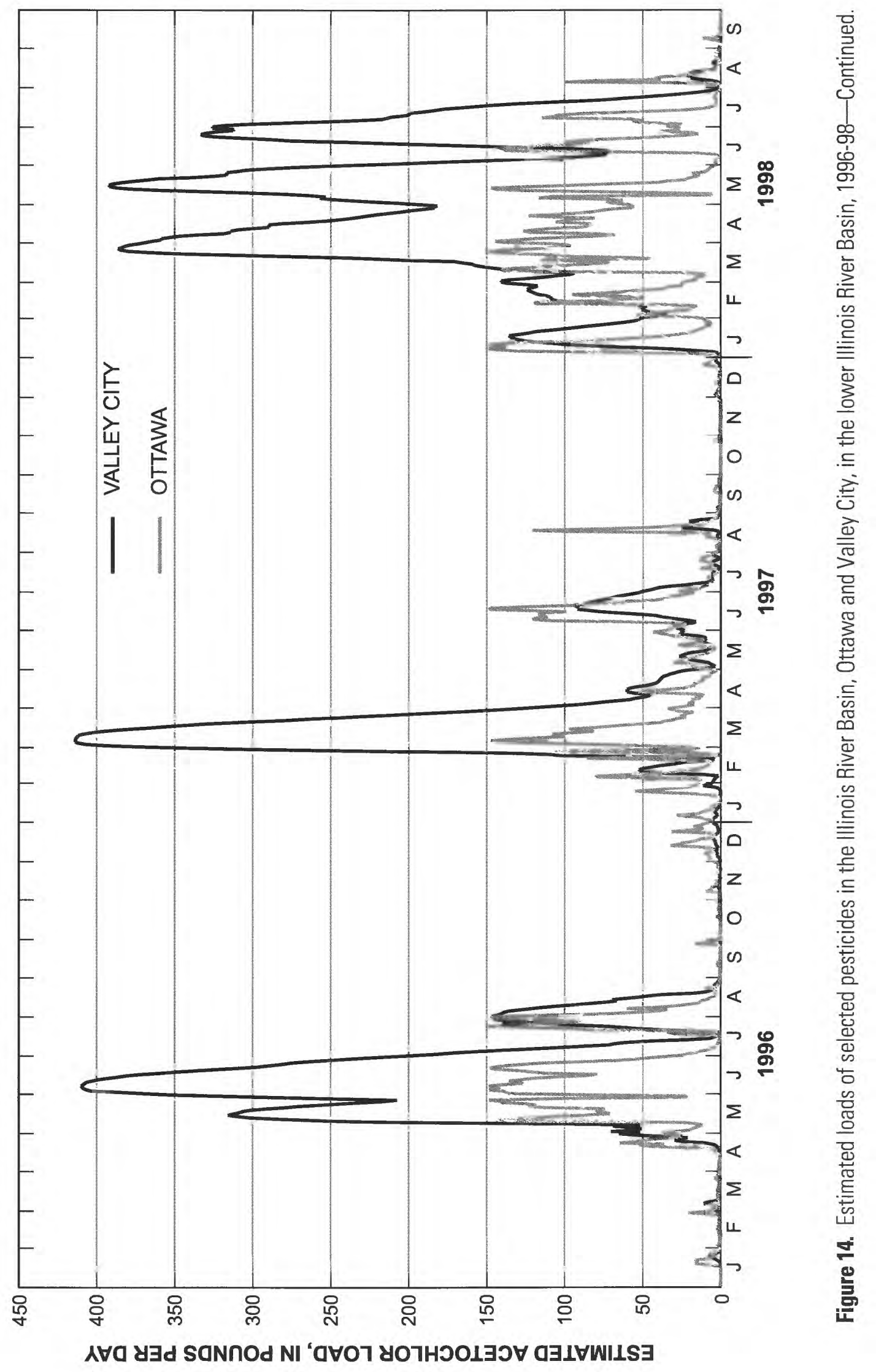




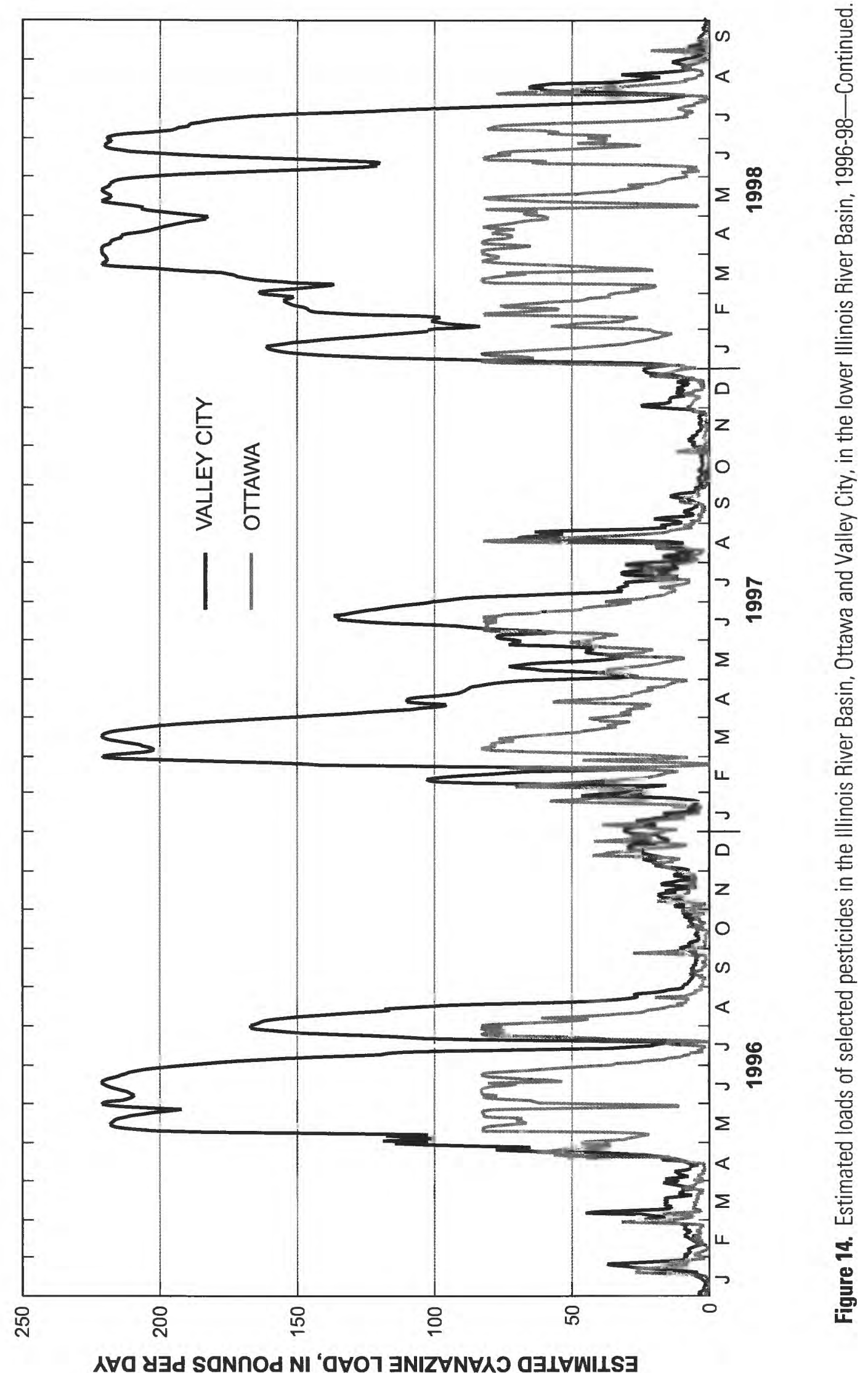


The estimated annual maximum peak load for atrazine at Valley City was approximately 1,200 pounds per day, whereas the estimated peak atrazine load at Ottawa was approximately 500 pounds per day (fig. 14). Similar percentage differences in relative loads also were estimated for acetochlor (peak atValley City of approximately 400 pounds per day compared to the peak at Ottawa of approximately 150 pounds per day, fig. 14) and cyanazine (peak at Valley City of about 225 pounds per day compared to the peak at Ottawa of approximately 75 pounds per day, fig. 14). The estimated annual load for acetochlor, atrazine, cyanazine, and metolachlor for the Illinois River at Ottawa and the Illinois River at Valley City are compared to the basin-wide pesticide application rate shown in table 14. The annual load contribution of each herbicide from the LIRB study area was computed by subtracting the estimated annual load at Ottawa from the estimated annual load at Valley City. The net basin-wide delivery ratio of each herbicide to surfacewater loads then was computed as the ratio of pounds of herbicide applied relative to the pounds of increase in the associated annual load between Ottawa and Valley City. The delivery ratios of atrazine always were the highest of the four herbicides. The average annual delivery ratio of atrazine was 2.1 percent. The average annual delivery ratios of metolachlor, acetochlor, and cyanazine ranged from 0.8 to 1.2 percent. In relative terms, each year the delivery ratio of atrazine was as much as approximately three times greater than the delivery ratios of metolachlor, acetochlor, and cyanazine (table 14). The sum of these pesticide loads is compared to the sum of the pesticides applied for the 1996-98 period in figure 15, which supports the generally accepted view that in large rivers only a small percentage (usually less than 5 percent) of the applied pesticides exit the basin by surface water.

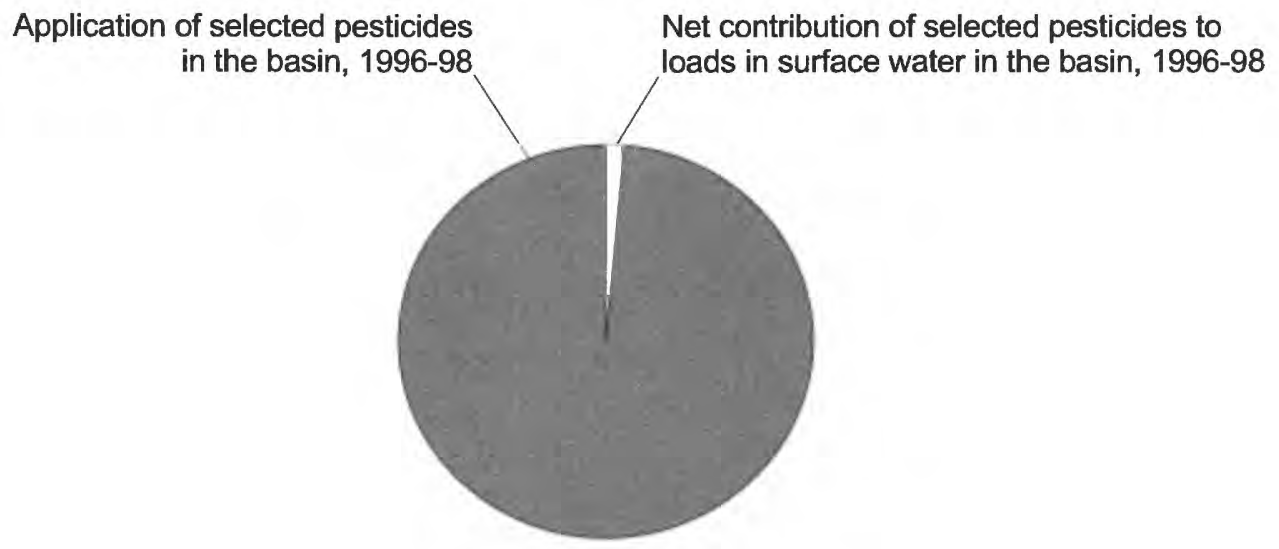

Figure 15. Comparison of net pesticide loads in surface water to pesticide use for acetochlor, atrazine, cyanazine, and metolachlor in the lower Illinois River Basin, 1996-98. 
Table 14. Estimated annual load, net-load increase, application quantity, and delivery ratio for selected pesticides in the lower Illinois River Basin, 1996-98

[Loads, net increase, and quantity applied are in pounds of active ingredient. WY, water year ${ }^{1}$; $\%$, delivery ratio is percent of active ingredient net increase relative to quantity applied]

\begin{tabular}{|c|c|c|c|c|c|}
\hline & $\begin{array}{c}\text { Ottawa } \\
\text { Estim }\end{array}$ & $\begin{array}{l}\text { Valley City } \\
\text { d load }\end{array}$ & $\begin{array}{c}\text { Net } \\
\text { increase }\end{array}$ & $\begin{array}{l}\text { Quantity } \\
\text { applied }\end{array}$ & $\begin{array}{c}\text { Delivery } \\
\text { ratio }\end{array}$ \\
\hline \multicolumn{6}{|c|}{ Acetochlor } \\
\hline${ }^{2}$ WY96 & 8,800 & 22,000 & 13,200 & $1,940,000$ & $0.7 \%$ \\
\hline WY97 & 8,000 & 16,400 & 8,400 & $2,170,000$ & $.4 \%$ \\
\hline WY98 & 13,100 & 40,500 & 27,400 & $1,740,000$ & $1.6 \%$ \\
\hline \multicolumn{6}{|l|}{ Atrazine } \\
\hline${ }^{2}$ WY96 & 23,600 & 79,700 & 56,100 & $3,210,000$ & $1.7 \%$ \\
\hline WY97 & 24,900 & 72,800 & 47,900 & $3,350,000$ & $1.4 \%$ \\
\hline WY98 & 31,000 & 14,1000 & 110,000 & $3,540,000$ & $3.1 \%$ \\
\hline \multicolumn{6}{|c|}{ Cyanazine } \\
\hline${ }^{2}$ WY96 & 7,100 & 20,600 & 13,500 & $2,260,000$ & $.6 \%$ \\
\hline WY97 & 9,000 & 20,600 & 11,600 & $1,220,000$ & $1.0 \%$ \\
\hline WY98 & 11,200 & 37,200 & 26,000 & $1,350,000$ & $1.9 \%$ \\
\hline \multicolumn{6}{|c|}{ Metolachlor } \\
\hline${ }^{2}$ WY96 & 14,800 & 29,900 & 15,100 & $2,330,000$ & $.6 \%$ \\
\hline WY97 & 14,600 & 25,900 & 11,300 & $2,710,000$ & $.4 \%$ \\
\hline WY98 & 18,100 & 51,800 & 33,700 & $2,600,000$ & $1.3 \%$ \\
\hline
\end{tabular}




\section{SUMMARY AND CONCLUSIONS}

Pesticides were sampled at eight surface-water sites in the lower Illinois River Basin between April 1996 and September 1998 as part of the NAWQA program. The basin is dominated by intense agricultural activity, most notably the production of corn and soybeans. An average of 3.6 million acres of corn and 3.3 million acres of soybeans were planted annually, and the planted soybean acreage increased by about 20 percent in 1998. Most water-quality samples (225 of 262 samples or 86 percent) were collected at four intensive-sample sites: the Illinois River at Ottawa, the Illinois River at Valley City, the La Moine River at Colmar, and the Sangamon River at Monticello. Thirty-one pesticides ( 23 herbicides and 8 insecticides) and 9 herbicide transformation products were detected. A majority of the pesticides detected at concentrations above their associated water-quality standard or guideline are in the chloroacetanilide- or triazine-class. Atrazine and metolachlor were detected in all samples, whereas cyanazine and prometon were detected in more than 90 percent of samples. Sampling also was done for selected triazine- and chloroacetanilide-class herbicide transformation products during the summer of 1998, plus the atrazine transformation product DEA during the entire 1996-98 data-collection period. Maximum concentrations observed for the 31 detected pesticides always occurred in 1 of 4 months: May, June, July, or August. Specifically, maximum concentrations were observed in May about 56 percent of the time, in June and August about 19 percent of the time each, and in July about 6 percent of the time. However, all chloroacetanilide- and triazine-class herbicides reached their maximum concentration in either May or June, as did some pesticides belonging to other chemical classes. A comparison of concentration to stream discharge for the herbicides acetochlor, atrazine, cyanazine, and metolachlor is made for the intensive sample sites for the 1996-98 data-collection period and shown in figure 16. Pesticides that were observed at the maximum concentration in July and August also were detected much less frequently overall, as the overall detection rate for these pesticides was from 7 percent to 37 percent. The most frequently detected insecticide was diazinon (present in 37 percent of samples) and it reached maximum concentration in August.
The four intensive sample sites were sampled for nine chloroacetanilide- and triazine-class herbicide transformation products during the summer 1998 and for the atrazine transformation product DEA during the 1996-98 data-collection period. The samples persistently had elevated concentrations of the chloroacetanilide-class transformation products at all locations and for all streamflow conditions. The total transformation product concentration, computed as the sum of the concentrations of the detected transformation product concentrations for each individual sample, generally increased with increasing streamflow (fig. 17). The concentration of the transformation product metolachlor ESA usually was about 10 times higher than the parent product in the mainstem of the Illinois River and sometimes up to 30 times higher in the La Moine River at Colmar and Sangamon River at Monticello. The acetochlor ESA and alachlor ESA concentrations persistently were elevated 5 to 10 times above the concentration of their parent products. The OXA transformation products of acetochlor and metolachlor also were observed at higher concentrations than their parent product, although these concentrations were lower than for the ESA transformation products. The concentration of the triazine-class transformation product DEA, a transformation product of atrazine, always was below that of its parent product. The concentration of the triazine-class transformation product DIA, which is a transformation product of both atrazine and cyanazine, was elevated slightly relative to DEA concentrations, although still below the concentration of its two parent products. Of the sampled triazine-class transformation products, the cyanazine transformation product CAM was observed at the highest absolute concentration and the highest concentration relative to its parent product. The deethylatrazine-to-atrazine ratio, computed for a 2-year period using the NWQL schedule 2010 concentration values, documents the timing of the spring first-flush of atrazine, when concentrations generally reached their annual maximum level, and documents the persistence of DEA through the winter months. 


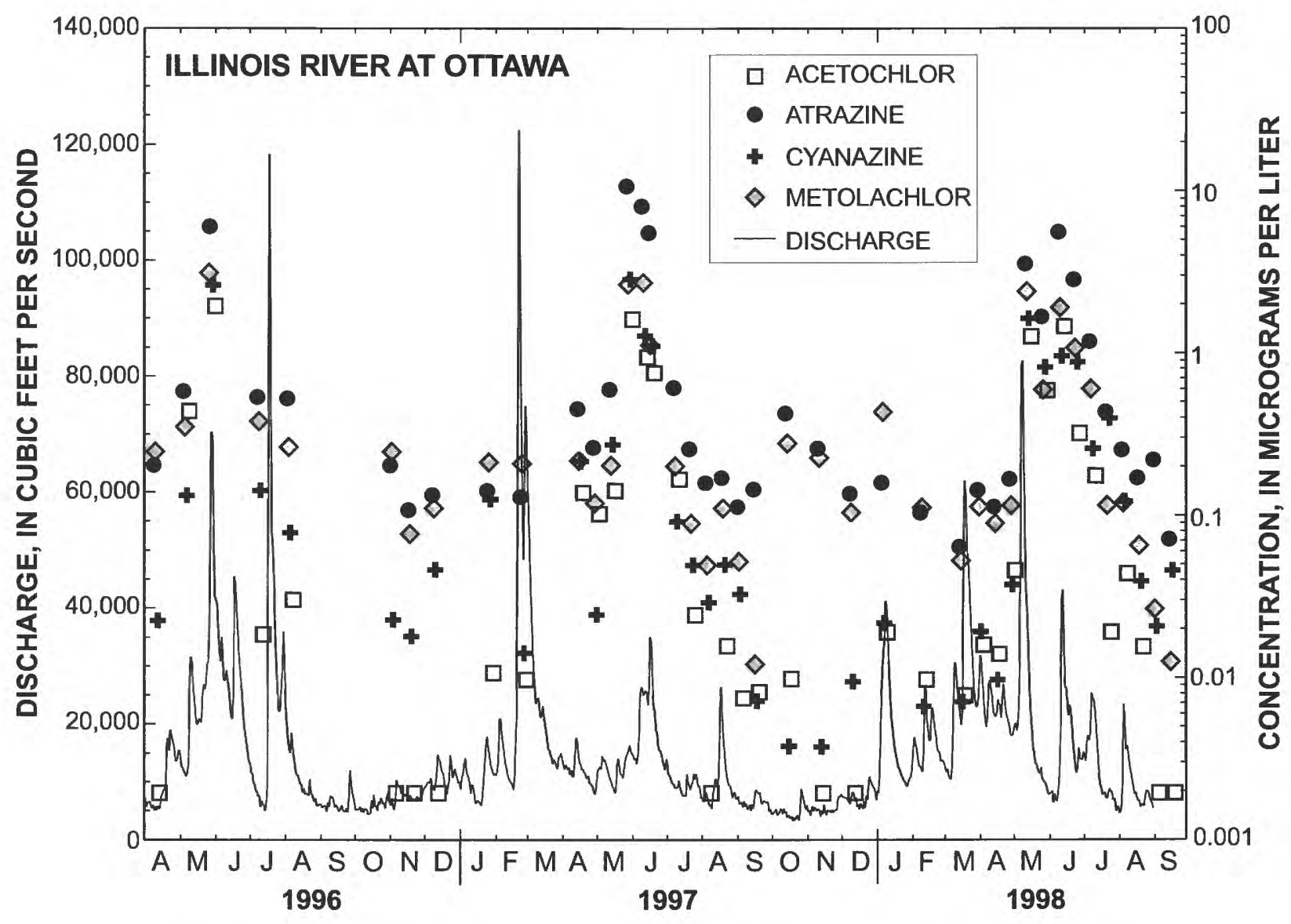

Figure 16. Comparison of the concentration of selected pesticides to stream discharge at the intensive sample sites in the lower Illinois River Basin, 1996-98. 


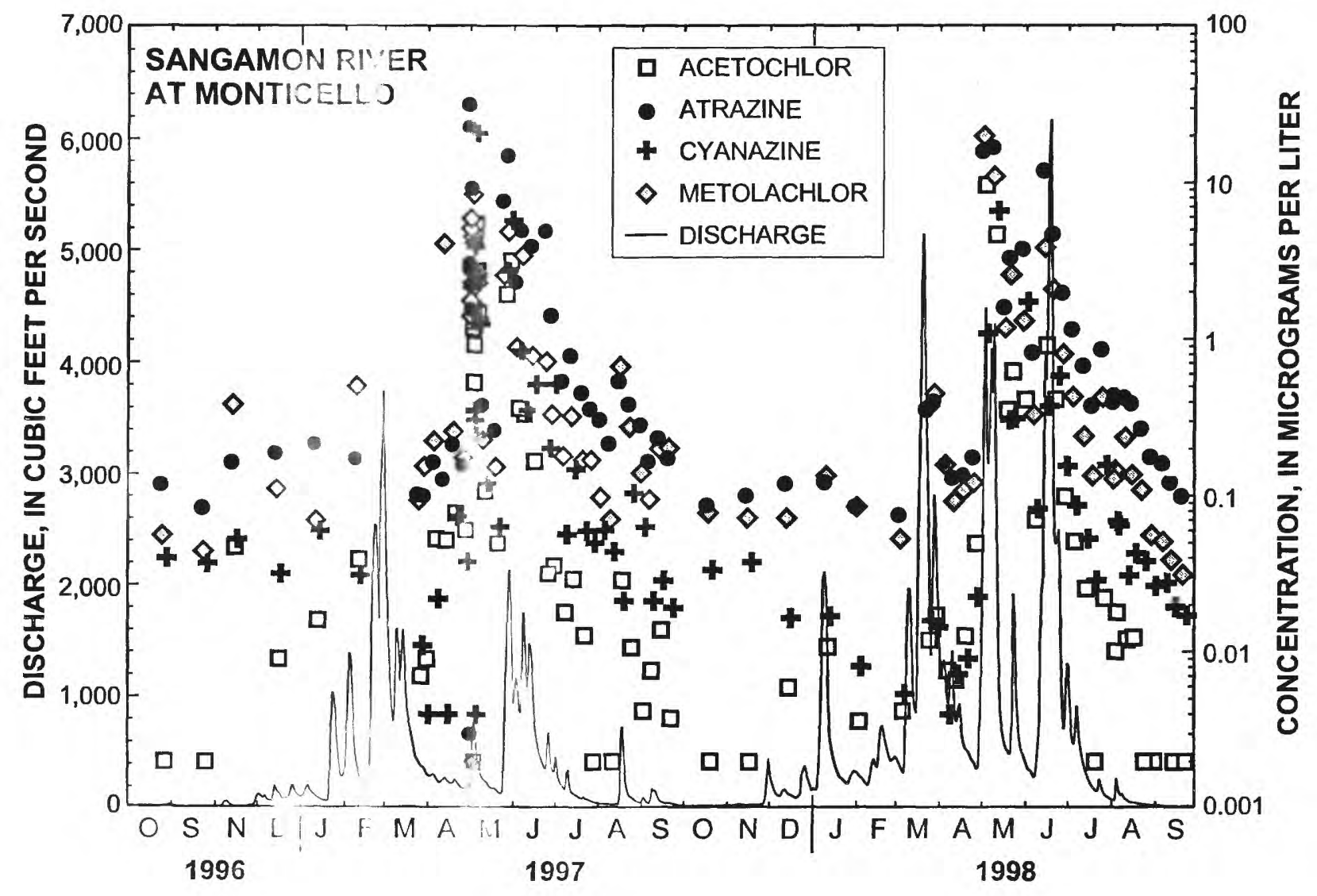

Figure 16. Comparison of the concentration of selected pesticides to stream discharge at the intensive sample sites in the lower Illinois River Basin, 1996-98-Continued. 


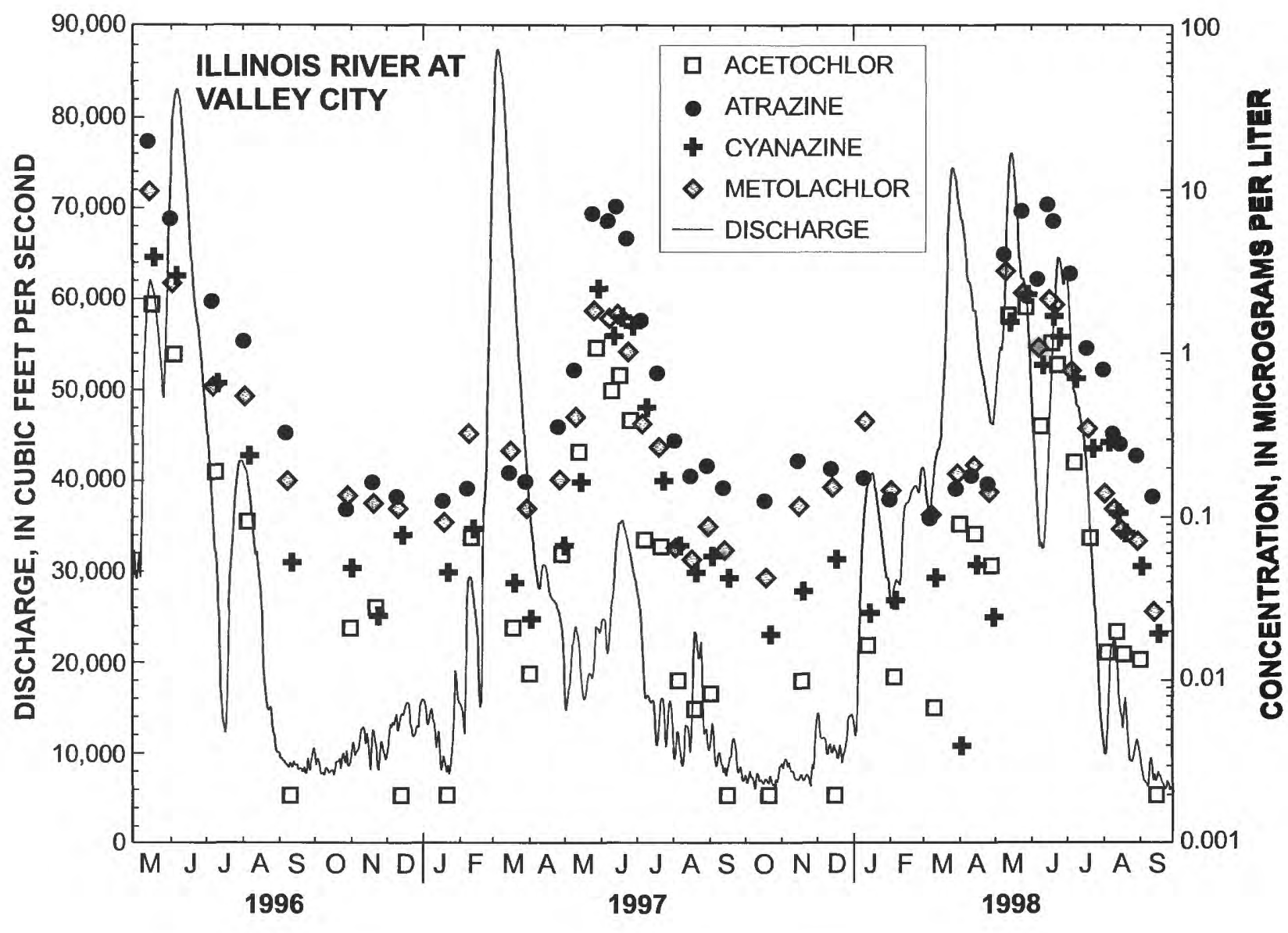

Figure 16. Comparison of the concentration of selected pesticides to stream discharge at the intensive sample sites in the lower Illinois River Basin, 1996-98-Continued. 


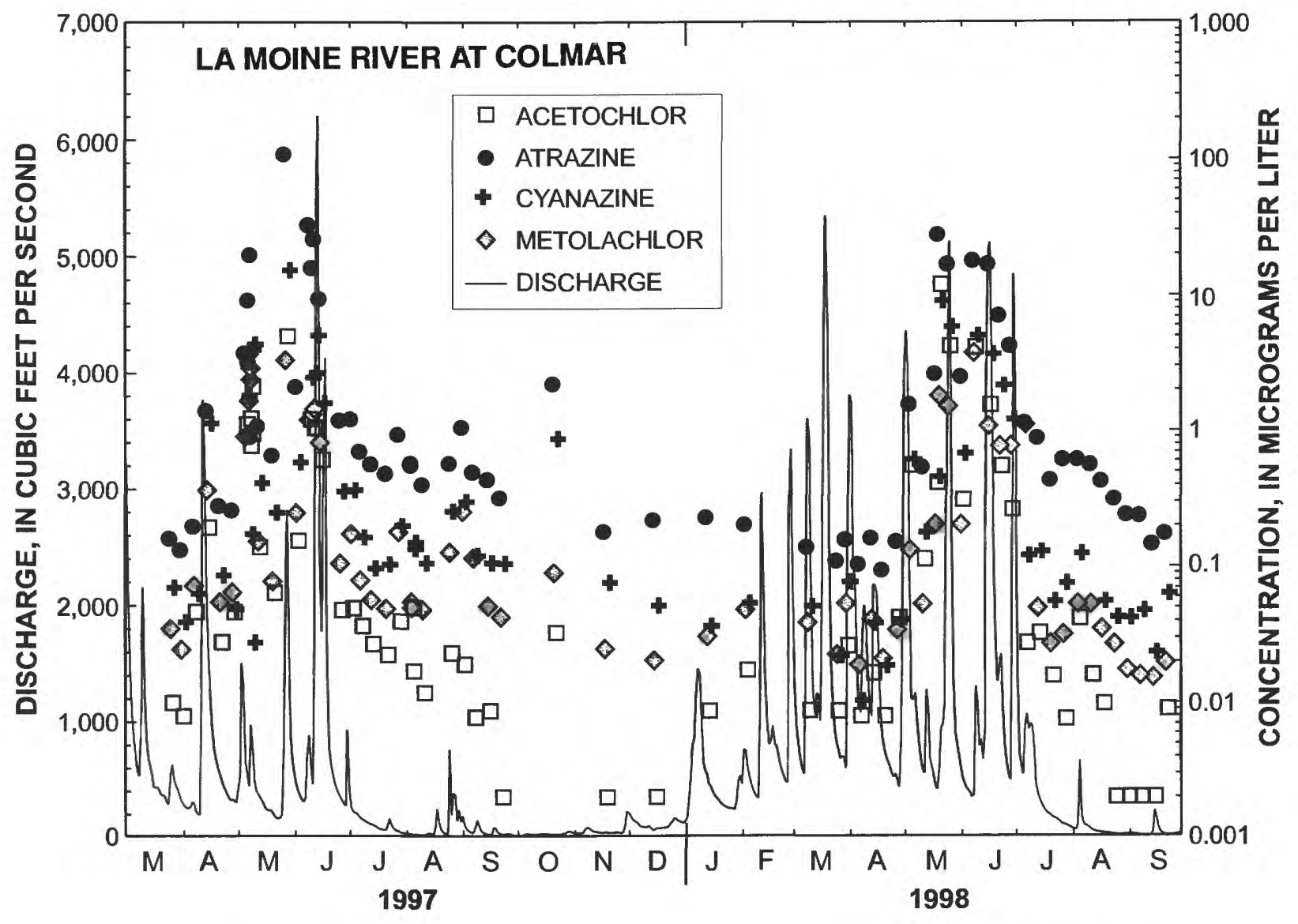

Figure 16. Comparison of the concentration of selected pesticides to stream discharge at the intensive sample sites in the lower Illinois River Basin, 1996-98-Continued. 


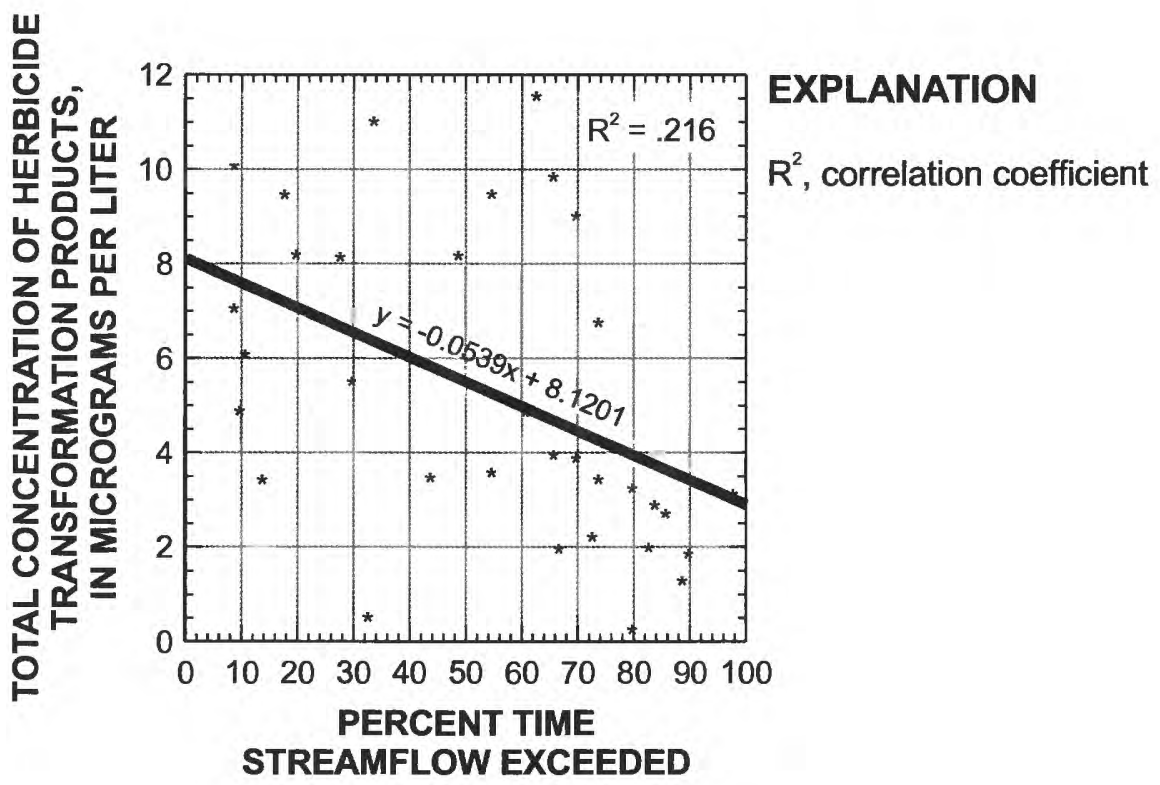

Figure 17. Relation of total chloroacetanilide- and triazine-class herbicide transformation product concentration to stream discharge in the lower Illinois River Basin, July-September 1998.

Either drinking-water standards or guidelines and aquatic-health criteria were exceeded for two triazine-class herbicides, atrazine and cyanazine, at the intensive sample sites. Aquatic-health criteria were exceeded for four pesticides: chlorpyrifos, diazinon, metolachlor, and 2,4-D. Chlorpyrifos and diazinon are organophosphate-class insecticides. Metolachlor and 2,4-D are herbicides of the chloroacetanilide- and chlorinated phenoxy-class, respectively. The pesticides alachlor, carbaryl, carbofuran, dieldrin, metribuzin, and triallate also were detected at elevated concentrations (within one-half or more of their respective drinking-water quality or aquatic-health standard or guideline), although none of these compounds ever exceeded their standard or guideline.

The herbicide atrazine sometimes exceeded the USEPA MCL drinking-water standard of $3 \mu \mathrm{g} / \mathrm{L}$ and the Canadian aquatic-health criteria of $1.8 \mu \mathrm{g} / \mathrm{L}$ at the four intensive sample sites during the 1996-98 datacollection period. Nearly all of these elevated atrazine concentrations were detected during the months of May and June when from 56 to 83 percent of the samples exceeded the atrazine MCL. The maximum atrazine concentrations were detected at the La Moine River at
Colmar and the Sangamon River at Monticello, and were estimated to be in excess of $30 \mu \mathrm{g} / \mathrm{L}$ in some samples, and over $100 \mu \mathrm{g} / \mathrm{L}$ in one sample. No other pesticide was detected at concentrations above the USEPA MCL for drinking water, although two herbicides were observed close to their MCL; alachlor had a maximum concentration of $0.93 \mu \mathrm{g} / \mathrm{L}(\mathrm{MCL}=2)$ at the La Moine River at Colmar and simazine was measured at a maximum concentration of $1.4 \mu \mathrm{g} / \mathrm{L}$ $(\mathrm{MCL}=4 \mu \mathrm{g} / \mathrm{L})$ at the Sangamon River at Monticello. The herbicide cyanazine frequently exceeded the USEPA HAL of $1 \mu \mathrm{g} / \mathrm{L}$ during May to June at the Illinois River sites of Ottawa and Valley City and the La Moine River at Colmar.

The primary factors that affected the detection frequency and concentration of pesticides in the surface water of the study area are the amount of pesticide used, the time-of-year (or seasonality), and the magnitude of streamflow. The agricultural herbicides that are applied in the greatest quantity - acetochlor, atrazine, cyanazine, metolachlor, and pendimethalin - also are among those detected the most frequently and at the highest concentrations. Notable exceptions are alachlor (74-percent detection rate) and simazine 
(78-percent detection rate), which were used in relatively small quantities as compared to the other frequently detected herbicides, yet still were detected frequently. A comparison of the annual pesticide use to the corresponding average sample concentration for selected chloroacetanilide-class, triazine-class, and all other classes of pesticides, for 1997 and 1998 are shown in figure 18.

The average sample pesticide concentration, computed as the mean of the mean of all detected pesticides for each set of samples for each month, peaked at nearly $1.1 \mu \mathrm{g} / \mathrm{L}$ in the month of May. The month of June had the second highest average sample pesticide concentration at nearly $0.7 \mu \mathrm{g} / \mathrm{L}$, and third was July at nearly $0.2 \mu \mathrm{g} / \mathrm{L}$. All other months had much lower average sample pesticide concentrations, ranging from about $0.05 \mu \mathrm{g} / \mathrm{L}$ to just over $0.1 \mu \mathrm{g} / \mathrm{L}$. Thus, the average sample pesticide concentration in May and June is approximately 15 to over 20 times higher than in most other months of the year. The data demonstrate a very close relation between the average sample pesticide concentration and the time-of-year (fig. 19). The effect of flow magnitude on pesticide concentrations also is notable. The average sample pesticide concentration for samples collected during high-flow conditions (equal to or greater than the 10percent exceedance probability), regardless of the timeof-year, was $0.99 \mu \mathrm{g} / \mathrm{L}$, compared to an average sample pesticide concentration of $0.28 \mu \mathrm{g} / \mathrm{L}$ for the other samples. Thus, the samples collected during high-flow conditions have, on average, over three times the pesticide concentration as compared to all the other samples.
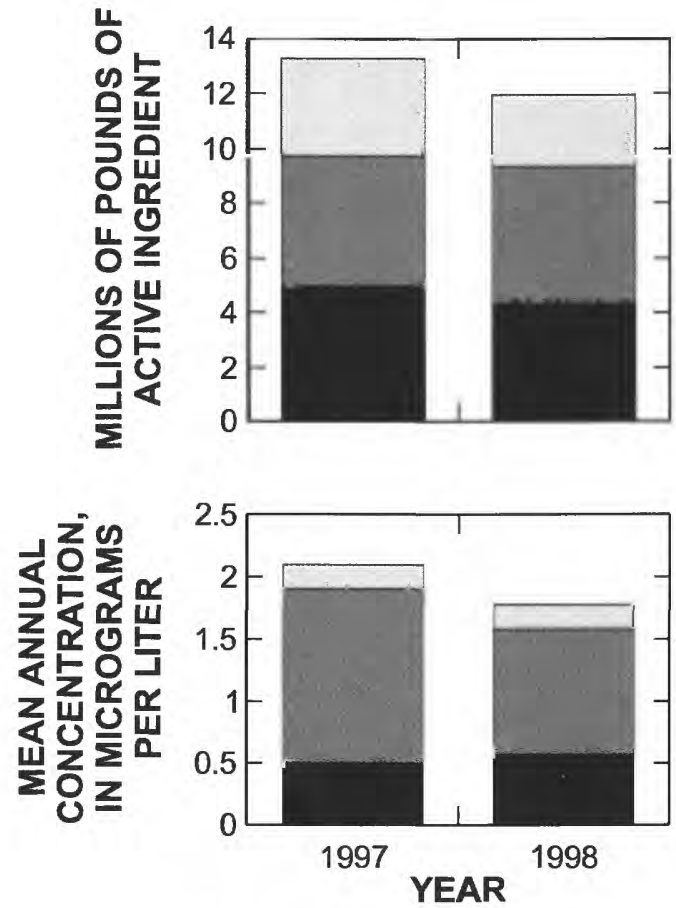

EXPLANATION

CHLOROACETANILIDES

TRIAZINES

\section{OTHER PESTICIDES}

Figure 18. Comparison of annual pesticide usage to mean annual concentration for selected pesticide chemical classes, lower Illinois River Basin, 1997-98. 


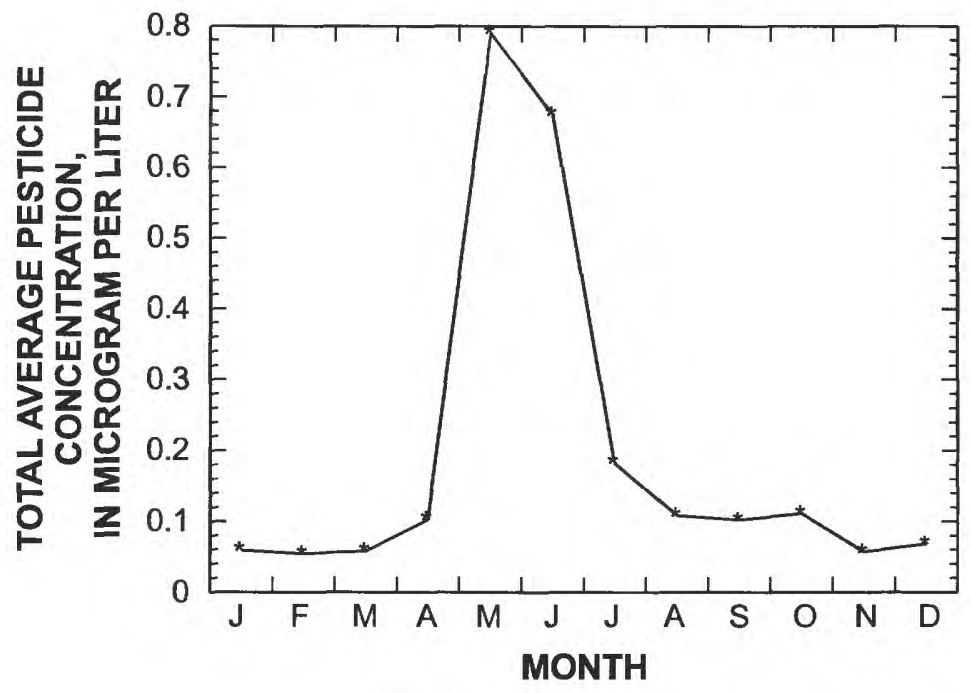

Figure 19. Monthly average pesticide concentration in the lower Illinois River Basin, 1996-98.

The effect of flow magnitude on the total concentration of pesticides for each sample, computed as the sum of the concentrations of all detected pesticides for each individual sample, also is important. Total pesticide concentration per sample, computed as the sum of all detected pesticide concentrations in the sample, can increase substantially with increasing streamflow (fig. 20). The combined effect of both seasonality and flow magnitude on pesticide occurrence in the study area is shown in figure 21, which suggests that seasonality is the most dominant factor affecting pesticide concentrations. The average pesticide concentration for samples collected in May to June and at high flow is about $1.3 \mu \mathrm{g} / \mathrm{L}$. The average concentration decreases to $0.70 \mu \mathrm{g} / \mathrm{L}$ for May to June samples collected at all other flow conditions. The average pesticide concentration decreases again to $0.12 \mu \mathrm{g} / \mathrm{L}$ in samples of high-flow conditions collected during all the months other than May and June. The average concentration then reaches a minimum of $0.10 \mu \mathrm{g} / \mathrm{L}$ for the remaining samples, which were collected in months other than May and June, and at lower flow conditions. The May to June samples only were about 30 percent of the total number of samples collected during the 1996-98 data-collection period, but provided most of the important insights to the annual variations and maximum concentration values of pesticides in the study area, especially with respect to water-quality standards and guidelines.

The daily and annual loads were computed for atrazine, metolachlor, acetochlor, and cyanazine for the Illinois River at Valley City and the Illinois River at Ottawa for 1996-98. Of these pesticides, the atrazine loads always were the greatest, peaking at over 1,200 pounds per day at Valley City. Pesticide loads at Valley City and Ottawa peaked between March and July of each year. The peak loads for atrazine, acetochlor, and cyanazine were greater at Valley City than at Ottawa, whereas the peak loads of metolachlor were similar at both sites. However, the annual pesticide loads at Valley City were from about two to over four times higher than the annual loads at Ottawa, reflecting both the use of pesticides in the LIRB and their transport to the basin outlet. The net contribution of selected pesticide loads from the LIRB study area was computed by subtracting the sum of loads at Ottawa from the sum of loads at Valley City for the period 1996-98. A comparison of the estimated net load to the pesticide use (fig. 15) suggests that only about 1-2 percent of the pesticides applied in the study area ultimately exit the study area at the Illinois River atValley City. 


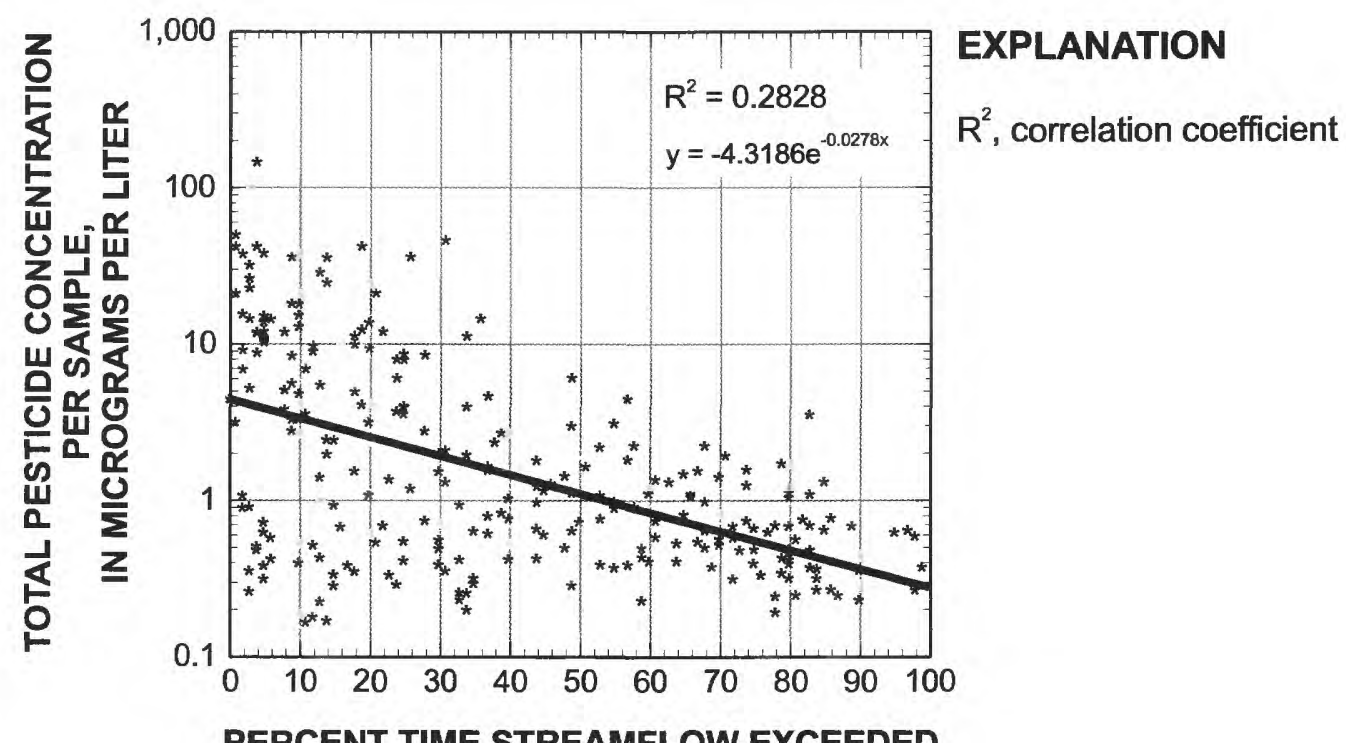

Figure 20. Relation of total pesticide concentration per sample to streamflow magnitude at all sample sites in the lower Illinois River Basin, 1996-98.

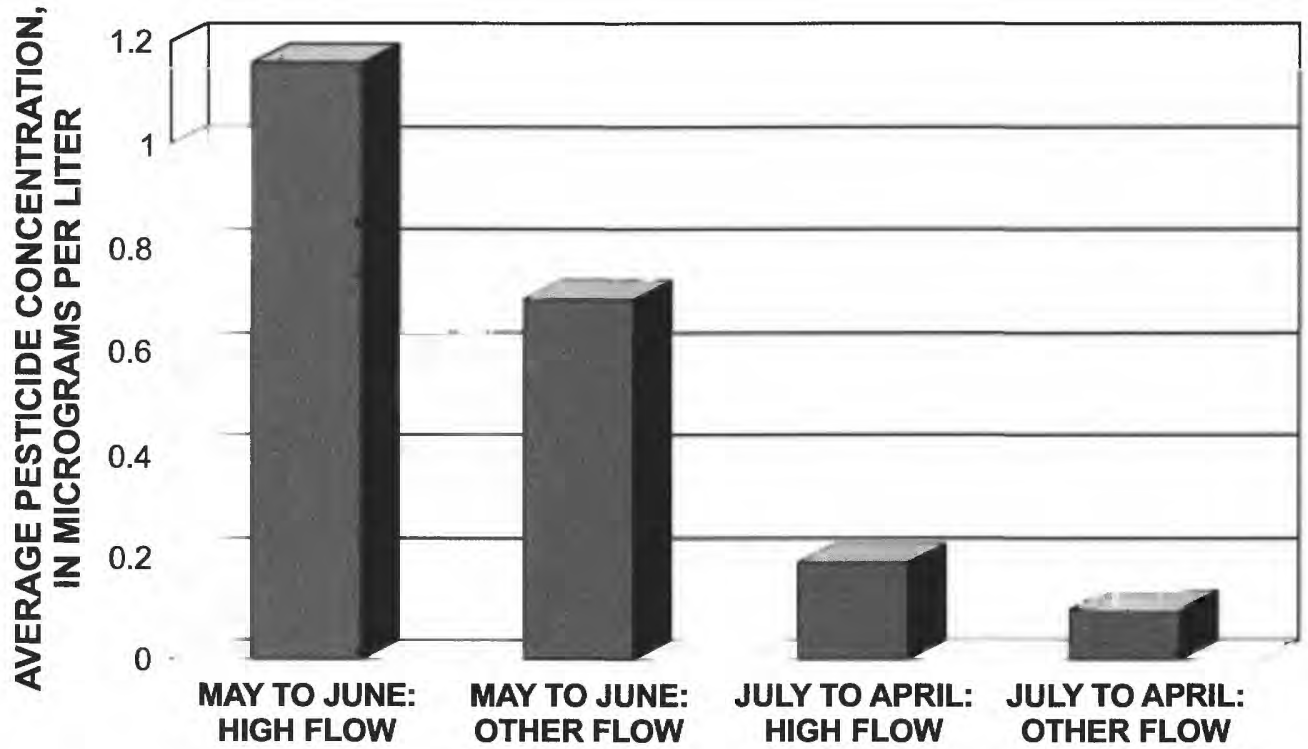

Figure 21. Comparison of average pesticide concentration to both seasonality and streamflow magnitude at all sample sites in the lower Illinois River Basin, 1996-98. 


\section{REFERENCES}

Adolphson, D.L., Fazio, D.J., and Harris, M.A., 2002, Habitat, biota, and sediment characteristics at selected stations in the lower Illinois River Basin, Illinois, 1995-98: U.S. Geological Survey WaterResources Investigations Report 01-4068, 52 p.

Anderson, J.R., Hardy, E.E., Roach, J.T., and Witmer, R.E., 1978, A land-use and land-cover classification system for use with remote sensor data: U.S. Geological Survey Professional Paper 964, $28 \mathrm{p}$.

Aspelin, A.L., 1994, Pesticides industry sales and usage, 1992 and 1993 market estimates: U.S. Environmental Protection Agency, Office of Pesticides Programs, Economic Analysis Branch Report 733-K-92-001, 33 p.

Baker, J.L., and Shiers, L.E., 1989, Effects of herbicide formulation and application method on wash off from corn residue: Transactions of the American Society of Agricultural Engineers, v. 32, p. 830-833.

Blevins, R.L., Frye, W.W., Baldwin, P.L., and Robertson, S.D., 1990, Tillage effects on sediment and soluble nutrient losses from a Maury silt loam soil: Journal of Environmental Quality, v. 19, p. 683-686.

Borin M., ed., 1997, Effects of tillage systems on herbicide dissipation - an experimental approach at field scale: Commission of the European Communities, Padova, Italy, Unipress, 247 p.

Canadian Council of Resource and Environment Ministers, 1997, Canadian water quality guidelines (rev. ed.): Ottawa, Ontario, Task Force on Water Quality Guidelines, Canadian Council of Resource and Environment Ministers, loose-leaf (originally published in 1987), 23 appendixes.

Capel, P.D., Nacionales, F.C., and Larson, S.J., 1995, Precision of a splitting device for water samples: U.S. Geological Survey Open-File Report 95-293, $6 \mathrm{p}$.

Cohn, T.A., 1988, Adjusted maximum likelihood estimation of the moments of lognormal populations from Type I censored samples: U.S. Geological Survey Open-File Report 88-350, 34 p.

Cohn, T.A., DeLong, L.L.,Gilroy, E.J., Hirsch, R.M., and Wells, D.K., 1989, Estimating constituent loads: Water Resources Research, 25(5), p. 937-942.
Cohn, T.A., Gilroy, E.J., and Baier, W.G., 1992, Estimating fluvial transport of trace constituents using a regression model with data subject to censoring: Proceedings of the Joint Statistical Meeting, Boston, August 9-13, 1992, p. 142-151.

Day, K.E., 1991, Pesticide transformation products in surface waters, effects on aquatic biota, in Somasundaram, L., and Coats, J.R., eds., Pesticide transformation products: Fate and significance in the environment: American Chemical Society Symposium series, v. 459, p. 217-241.

Edwards, T.K., and Glysson, D.G., 1988, Field methods for measurement of fluvial sediment: U.S. Geological Survey Open-File Report 86-531, $118 \mathrm{p}$.

Extoxnet, 2000, Extension Toxicology Network, Web site maintained by Oregon State University, accessed on March 13, 2000, at URL http:// ace.ace.orst.edu/info/extoxnet

Gilliom, J.G., Alley, W.M., and Gurtz, M.E., 1995, Design of the National Water-Quality Assessment Program--Occurrence and distribution of waterquality conditions: U.S. Geological Survey Circular 1112, $33 \mathrm{p}$.

Gilroy, E.J., Hirsch, R.M., and Cohn, T.A., 1990, Mean square error of regression-based constituent transport estimates: Water Resources Research, 26(9), p. 2069-2077.

Hall, J.K., Hartwig, N.L., and Hoffman, L.D., 1984, Cyanazine losses in runoff from no-tillage corn in "living" and dead mulches vs. unmulched, conventional tillage: Journal of Environmental Quality, v. 13, p. 105-110.

Hall, J.K., and Mumma, R.O., 1994, Dicamba mobility in conventionally and no-tilled soil: Soil Tillage Research, v. 30, p. 3-17.

Huff, F.A., and Angel, J.R., 1989, Frequency distributions and hydroclimatic characteristics of heavy rainstorms in Illinois: Illinois State Water Survey, Bulletin 70, 135 p.

Illinois Agricultural Statistics Service, 1997, Annual summary: Bulletin 97-1, 127 p.

1998, Annual summary: Bulletin 98-1, 125 p. 1999, Annual summary: Bulletin 99-1, 117 p.

Illinois Department of Agriculture, 2000, T by 2000: Soil Conservation for the 21 st Century, accessed March 28, 2000, at URL http://www.agr.state.il.us/ TBY2000.html 
Illinois Department of Natural Resources, 1994, The changing Illinois environment--critical trends-Technical report of the Critical Trends Assessment Project, volume 3--Ecological Resources: Illinois Natural History Survey Division, $242 \mathrm{p}$.

1996, Illinois land cover--an atlas: Springfield, Ill., Critical Trends Assessment Phase II: Department of Natural Resources, $157 \mathrm{p}$.

Illinois State Water Survey, 2000, Illinois climate data: accessed March 8, 2000, at URL http:// www.sws.uiuc.edu/atmos/statecli/maps/maps.htm

International Joint Commission, 1999, Revised Great Lakes Water Quality Agreement of 1978, as amended by Protocol signed November 18, 1987 : International Joint Commission United States and Canada, September, 1989 (http://www.ijc.org/ agree/quality.html\#art5). See also Annex I, Specific objectives (http://www.ijc.org/agree/ quality.html\#ann1).

Larson, S.J., Capel, P.D., and Majewski, M.S., 1997, Pesticides in surface water-distributions, trends, and governing factors: Chelsea, Mich., Ann Arbor Press, $373 \mathrm{p}$.

Larson, S.J., Gilliom, R.J., and Capel, P.D., 1999, Pesticides in streams of the United States-initial results from the National Water-Quality Assessment program: U.S. Geological Survey Water-Resources Investigations Report 98-4222, $99 \mathrm{p}$.

LaTour, J.K., Maurer, J.C., Wicker, T.L., and Gioja, J.M., 1999, Water Resources Data-Illinois, Water Year 1998: U.S. Geological Survey Water-Data Report IL-98, on CD-ROM in HTML format in accordance with ISO 9660 and Macintosh HFS standards.

Leonard, R.A., 1990, Movement of pesticides into surface water, in Cheng, H.H., ed., Pesticides in the soil environment: Processes, impacts, and modeling: Soil Society of America, Madison. Wis., p. 303-349.

Moyer, L., and Cross, J., 1990, Pesticide monitoring-Illinois EPA's summary of results 1985-1989: Illinois Environmental Protection Agency, Water Pollution Control Report 90-297, $143 \mathrm{p}$.

Seta, A.K., Blavins, R.L., Frye, W.W., and Barfield, B.J., 1993, Reducing soil erosion and agricultural chemical losses with conservation tillage: Journal of Environmental Quality, v. 22, p. 661-665.
Shelton, L.R., 1994, Field guide for collecting and processing stream-water samples for the National Water-Quality Assessment Program: U.S. Geological Survey Open-File Report 94-455, 42 p.

Thurman, E.M., and Fallon, J.D., 1996, The deethylatrazine/atrazine ratio as an indicator of the onset of the spring flush of herbicides into surface water of the Midwestern United States: International Analytical Chemistry, v. 65, p. 203-214.

U.S. Department of Commerce, 2000, Population Estimates Program, Population Division, County population estimates for July 1, 1999--Illinois: Bureau of the Census, March 2000: accessed April 3, 2001, at URL http://www.census.gov/ population/estimates/county/co-99-1/99C1_17.txt

U.S. Environmental Protection Agency, 1988, Draft guide to drinking water health advisories: U.S. Environmental Protection Agency, Office of Drinking Water, Criteria and Standards Division, August 1988.

1989, Drinking water health advisory, pesticides: Chelsea, Michigan, Lewis Publishers, 819 p.

1994 (updated October 2000), Acetochlor desk statement, Office of Pesticide Programs: accessed March 7, 2001, at URL www.epa.gov/oppefed1/ aceto/index.htm

1999a, Drinking water and health advisories:

U.S. Environmental Protection Agency, Office of Water: accessed March 27, 2000, at URL http:// www.epa.gov/OST/Tools/dwstds.html

1999b, National Recommended Water Quality Criteria-Correction: Office of Water Report 822-Z-99-001, 26 p.

2000, Office of Ground Water and Drinking Water-Databases: accessed March 13, 2000, at URL http://www.epa.gov/ogwdw000

U.S. Geological Survey, 2000a, National Water-Quality Assessment (NAWQA) method and guidelines protocols: accessed March 6, 2000, at URL http:// wwwrvares.er.usgs.gov/nawqa/protocols/ doc_list.html

2000b, National Water-Quality Assessment (NAWQA) Report Results: accessed March 17, 2000, at URL http://orbddwimdn.er.usgs.gov/ nawqa_www/NWQ_MNG.STDS_REPORT.show 
Warner, K.L., 1998, Water-quality assessment of the lower Illinois River Basin--Environmental setting: U.S. Geological Survey Water-Resources Investigations Report 97-4165, 50 p.

Werner, S.L., Burkhardt, M.R., and DeRusseau, S.N., 1996, Methods of analysis by the U.S. Geological Survey National Water Quality Laboratorydetermination of pesticides in water by CarbopakB solid phase extraction and high-performance liquid chromatography: U.S. Geological Survey Open-File Report 96-216, 42 p.

Wicker, T.L., LaTour, J.K., and Maurer, J.C., 1997, Water Resources Data-Illinois, Water Year 1996, Volume 2, Illinois River Basin: U.S. Geological Survey Water-Data Report IL-96-2, 398 p.

1998, Water Resources Data--Illinois, Water Year 1997, Volume 2, Illinois River Basin: U.S. Geological Survey Water-Data Report IL-92-2, $360 \mathrm{p}$.
Zaugg, S.D., Sandstrom, M.W., Smith, S.G., and Fehlberg, K.M., 1995, Methods of analysis by the U.S. Geological Survey National Water Quality Laboratory- determination of pesticides in water by C-18 solid-phase extraction and capillarycolumn gas chromatography/mass spectrometry with selected-ion monitoring: U.S. Geological Survey Open-File Report 95-181, 49 p.

Zimmerman, L.R., and Thurman, E.M., 1999, Method of analysis by the U.S. Geological Survey Organic Geochemistry Research Group-Determination of triazine and chloroacetanilide herbicides in water by solid-phase extraction and capillary-column gas chromatography/mass spectrometry with selected ion monitoring: U.S. Geological Survey OpenFile Report 98-634, 21 p. 
District Chief

U.S. Geological Survey

$221 \mathrm{~N}$. Broadway

Urbana, IL 61801 